\title{
Characterization and Shelf-Life of Soluble Protein Powder Derived from Silver Carp (Hypophthalmichthys molitrix)
}

Derek Warren

Follow this and additional works at: https://researchrepository.wvu.edu/etd

\section{Recommended Citation}

Warren, Derek, "Characterization and Shelf-Life of Soluble Protein Powder Derived from Silver Carp (Hypophthalmichthys molitrix)" (2017). Graduate Theses, Dissertations, and Problem Reports. 6917. https://researchrepository.wvu.edu/etd/6917

This Thesis is protected by copyright and/or related rights. It has been brought to you by the The Research Repository @ WVU with permission from the rights-holder(s). You are free to use this Thesis in any way that is permitted by the copyright and related rights legislation that applies to your use. For other uses you must obtain permission from the rights-holder(s) directly, unless additional rights are indicated by a Creative Commons license in the record and/ or on the work itself. This Thesis has been accepted for inclusion in WVU Graduate Theses, Dissertations, and Problem Reports collection by an authorized administrator of The Research Repository @ WVU. For more information, please contact researchrepository@mail.wvu.edu. 
Characterization and shelf-life of soluble protein powder derived from silver carp (Hypophthalmichthys molitrix).

Derek Warren

\author{
A thesis submitted to the \\ Davis College of Agriculture, Forestry and Consumer Sciences \\ at West Virginia University \\ In Partial Fulfillment of the Requirements \\ for the degree of \\ Master of Science \\ in
}

Nutritional and Food Sciences

Kristen E. Matak, Ph. D., Chair

Jacek Jaczynski, Ph. D.

Cangliang Shen, $\mathrm{Ph} . \mathrm{D}$

Department of Animal and Nutritional Sciences

Morgantown, West Virginia

2017

Keywords: Silver carp, Protein recovery, Sarcoplasmic protein Copyright 2017 Derek Warren 


\section{ABSTRACT \\ Characterization and shelf-life of soluble protein powder derived from silver carp (Hypophthalmichthys molitrix).}

\section{Derek Warren}

Better management of current resources is one method to feed an ever growing population.

Currently, sarcoplasmic proteins, water soluble proteins making up $25-30 \%$ of total protein in fish, are disposed of through municipal water treatment in surimi waste wash water. There is potential for the development of a simple method to reclaim and repurpose soluble protein from surimi wash water. The objective of this research was to 1) determine if processing temperature impacted protein recovery, 2) characterize the soluble protein powder, and 3) compare shelf stability to that of a similar protein powder ( $80 \%$ whey protein concentrate WPC). Separation temperature variations of 4,20 , and $40^{\circ} \mathrm{C}$ produced minimal changes in proximate composition, amino acid profiles, mineral profiles, and fatty acid profiles. The recovered powder was rich in protein at $82.42 \%$ (dry) and met all adult essential amino acid requirements. Approximately, $3.25 \%$ lipid remained in the powder which was composed of $25 \%$ polyunsaturated fatty acids and 29\% monounsaturated fatty acids. SDS-PAGE indicated large numbers of small molecular weight protein bands consistent with sarcoplasmic proteins. Recovered protein powder was less soluble than WPC. However, WPC contained lecithin and SDS-PAGE revealed proteins of low to medium molecular weights. Shelf-life stability of the protein powder was analyzed by measuring changes in color, lipid oxidation, $\mathrm{pH}$, water activity, and amino acid profile with WPC and protein powder samples stored at 20 and $30^{\circ} \mathrm{C}$ for 9 months. The soluble protein powder stored at $30^{\circ} \mathrm{C}$ had the most significant reductions $(\mathrm{p}<0.05)$ in $\mathrm{pH}(-0.34)$, whiteness $(-15.31)$ and lysine content (-10.50 mg/g protein). Results from this study suggest that protein separation temperature has limited effect on nutrient characterization and the resulting protein powder is 
nutrient dense. Although the powder was not as soluble and shelf-stable as WPC, inclusion of additional phospholipids (like lecithin) and antioxidants would likely improve this outcome. 


\section{ACKNOWLEDGEMENTS}

This project was funded by Agriculture and Food Research Initiative Competitive Grant no. 2015-67017-23084 from the USDA National Institute of Food and Agriculture.

I would like to thank my advisor, Dr. Kristen E. Matak for her guidance. I could not have done this without her support and our weekly minute meetings.

Thank you to my committee members, Dr. Jacek Jaczynski, Dr. Janet Tou, and Cangliang Shen for always having an open office door. I would like to thank the faculty and staff in the Animal and Nutritional Sciences Department at West Virginia University for their continuous support.

A special thank you to Sarah Beamer and Ilgin Paker for their guidance, training, and support in completing this project. I appreciate the hours you spent assisting me in the laboratory and wish Sarah the best with going into retirement.

Finally, my deep appreciation to my family for encouraging me to continue my education. This project would not have been completed without your support and guidance. 


\section{TABLE OF CONTENTS}

ABSTRACT

ii

ACKNOWLEDGEMENTS

iv

LIST OF TABLES

vii

LIST OF FIRGURES

ix

CHAPTER I 1

INTRODUCTION

1

REFERENCES

\section{4}

CHAPTER II 6

REVIEW OF LITERATURE

$\begin{array}{ll}\text { Protein Characterization } & 6\end{array}$

Filtration Units $\quad 6$

Coagulating Agents $\quad 9$

Characteristics of sarcoplasmic proteins $\quad 12$

Shelf-life analysis $\quad 19$

$\begin{array}{ll}\text { REFERENCES } & 25\end{array}$

\begin{tabular}{lr} 
CHAPTER III & 28 \\
\hline
\end{tabular}

$\begin{array}{ll}\text { INTRODUCTION } & 31\end{array}$

MATERIALS AND METHODS $\quad 34$

$\begin{array}{ll}\text { RESULTS AND DISCUSSION } & 41\end{array}$

Proximate Composition $\quad 41$

Mineral Profile $\quad 42$

Fatty Acid Profile $\quad 43$

Amino Acid Profile $\quad 44$

SDS-PAGE $\quad 45$

2-D Electrophoresis $\quad 46$

$\begin{array}{ll}\text { Protein Solubility } & 47\end{array}$

$\begin{array}{ll}\text { CONCLUSION } & 49\end{array}$ 
$\begin{array}{ll}\text { REFERENCES } & \mathbf{5 0}\end{array}$

\begin{tabular}{lr} 
CHAPTER IV & 64 \\
\hline
\end{tabular}

$\begin{array}{ll}\text { INTRODUCTION } & 66\end{array}$

$\begin{array}{ll}\text { MATERIALS AND METHODS } & 68\end{array}$

RESULTS AND DISCUSSION

Water Activity $\quad 72$

$\begin{array}{ll}\text { Colorimetry } & 74\end{array}$

$\mathrm{pH}$

75

TBARs

75

Amino Acid Profile

76

$\begin{array}{ll}\text { CONCLUSION } & 78\end{array}$

$\begin{array}{ll}\text { REFERENCES } & 79\end{array}$

\begin{tabular}{lr} 
CHAPTER V & 91 \\
\hline
\end{tabular}

$\begin{array}{ll}\text { APPENDIX } & 91\end{array}$ 


\section{LIST OF TABLES}

\section{CHAPTER III}

TABLE 1: Proximate composition (\% dry weight basis) and recovery yields of sarcoplasmic protein powder recovered at 4,20 , and $40^{\circ} \mathrm{C}$.

TABLE 2: Mineral profile of sarcoplasmic protein powder recovered at 4,20 , and $40^{\circ} \mathrm{C} .56$

TABLE 3: Fatty acid composition of sarcoplasmic protein powder recovered at 4,20 , and $40^{\circ} \mathrm{C}$ and freeze-dried initial homogenate.

TABLE 4: Amino acid composition (mg/g protein) of silver carp sarcoplasmic protein powder, initial silver carp homogenate, $80 \%$ whey protein, and the amino acid requirements for adults and infants.

\section{CHAPTER IV}

TABLE 1: Proximate composition (\% dry weight basis) of the recovered soluble protein powder and whey protein concentrate.

TABLE 2: Change in amino acid profile of WPC stored at $20^{\circ} \mathrm{C}$ for 3,6 , and 9 months 87

TABLE 3: Change in amino acid profile of WPC stored at $30^{\circ} \mathrm{C}$ for 3,6 , and 9 months $\mathbf{8 8}$

TABLE 4: Change in amino acid profile of SPP stored at $20^{\circ} \mathrm{C}$ for 3,6 , and 9 months

TABLE 5: Change in amino acid profile of SPP stored at $30^{\circ} \mathrm{C}$ for 3,6 , and 9 months

\section{CHAPTER V}

TABLE 1: Water activity of whey protein concentrate and soluble protein powder stored at 20 and $30^{\circ} \mathrm{C}$

TABLE 2: Whiteness of whey protein concentrate and soluble protein powder stored at 20 and $30^{\circ} \mathrm{C}$

TABLE 3: $\mathrm{pH}$ of whey protein concentrate and soluble protein powder stored at 20 and $30^{\circ} \mathrm{C}$ 
TABLE 4: Lipid oxidation of whey protein concentrate and soluble protein powder stored at 20 and $30^{\circ} \mathrm{C}$

TABLE 5: Amino acid profile of WPC stored at $20^{\circ} \mathrm{C}$ for 9 months 98

TABLE 6: Amino acid profile of WPC stored at $30^{\circ} \mathrm{C}$ for 9 months 99

TABLE 7: Amino acid profile of SPP stored at $20^{\circ} \mathrm{C}$ for 9 months 100

TABLE 8: Amino acid profile of SPP stored at $30^{\circ} \mathrm{C}$ for 9 months 101 


\section{LIST OF FIGURES}

\section{CHAPTER II}

FIGURE 1: 2D electrophoresis gels of high-salt soluble (1A) and low-salt-soluble (2B) proteins from freshly defrosted rainbow trout.

\section{CHAPTER III}

FIGURE1: Linear regression plots of SFA (A), MUFA (B), and PUFA (C) concentrations in silver carp sarcoplasmic protein processed at 4,20 , and $40^{\circ} \mathrm{C}$

FIGURE 2: SDS-PAGE gel of silver carp sarcoplasmic protein powder processed at $4^{\circ} \mathrm{C}$, whey protein concentrate, and initial silver carp homogenate.

FIGURE 3: Representative 2-demensional electrophoresis gels of silver carp sarcoplasmic protein powders $(A)$, Whey protein concentrate $(B)$ and initial silver carp homogenate $(C)$.

61

FIGURE 4: Solubility of recovered protein powder and WPC 80 in solutions of varying ionic strengths of $\mathrm{CaCl}_{2}, \mathrm{KCl}$, and $\mathrm{NaCl}$.

FIGURE 5: Solubility of recovered protein powder and WPC 80 in solutions with varying pH.

\section{CHAPTER IV}

FIGURE 1: Water activity of SPP and WPC stored at 20 and $30^{\circ} \mathrm{C}$ for 9 months

FIGURE 2: Whiteness of 9 month stored protein powders (SPP and WPC) stored at 20 and $30^{\circ} \mathrm{C}$

FIGURE 3: Changes in $\mathrm{pH}$ as a result of storage of SPP and $\mathrm{WPC}$ at 20 or $30^{\circ} \mathrm{C}$ for 9 months

84

FIGURE 4: Lipid oxidation values of SPP and WPC stored for 9 months at 20 or $30^{\circ} \mathrm{C}$

85

\section{CHAPTER V}

FIGURE 1: Nutrition facts and ingredients of whey protein concentrate purchased from a food whole sale website (bulkfoods.com). 
FIGURE 2: Comparison of total essential amino acid content (A) and lysine content $(\mathbf{B})$ between stored WPC and SPP samples at 0, 3, 6, and 9 months.

FIGURE 3: Degradation of total essential amino acid content (A) and lysine content (B) in WPC and SPP stored for 9 months and 20 and $30^{\circ} \mathrm{C}$. 


\section{Chapter I}

\section{Introduction}

Fish are a major source of animal protein in the human diet. According to the Food and Agriculture Organization of the United Nations (FAO), the global consumption of fish and other aquatic animals has quadrupled in the past 50 years (Knap, 2011). In general, fish and fish products are rich in quality protein, low in total fat, and provide a source for key micronutrients such as fat soluble vitamins and minerals. All fish exceed the requirement of having more than 12 percent energy from protein to be considered high in protein and are a good source of all essential amino acids. The high levels of omega-3 polyunsaturated fatty acids in some fish have been shown to play a role in cardiovascular and brain health (Ruxton, 2011). With strong evidence behind the health benefits of fish consumption, it is understandable that people are encouraged to increase their consumption two or three-fold (FAO-WHO, 2011). With the recommendation to eat more seafood and the growing global population, it is important to more effectively utilize available resources.

In the last 50 years, world fish consumption has nearly doubled, from an average of $9.9 \mathrm{~kg}$ to $19.2 \mathrm{~kg}$ per capita (FAO, 2014). Natural capture production reached its maximum in the 1980's, leaving aquaculture production to make up of the difference. Global aquaculture production has increased an average of 6.2 percent annually between 2000 and 2012, down 3.3 percent for 1990 to 2000 (FAO, 2014). With the world population currently increasing at a rate of 1.6 percent a year, fish processing needs to be more efficient. One way this can be done is by recovering marketable byproducts. The recovery yield from fish filet processing ranges between 30 and 40 percent of the whole fish by weight, with 60 to 70 percent of the fish ending up as by-products (Gildberg, 2002, Chen and Jaczynski, 2007). By-products are used in fish meals for animal feed, biofuels, natural pigments, 
cosmetics, nutrition supplement (Arvanitoyannis \& Kassaveti, 2006). Solid fish waste has numerous uses, but the waste water does not. It is common for process water waste to be disposed of through the municipal sewers (FAO, 2005b). During surimi processing, fish fillets are minced and repeatedly rinsed to concentrate the myofibrillar proteins leaving viscera, blood, slime, and scales in waste water (Islam et al. 2004). In addition, up to $2.3 \%$ soluble proteins (Wibowo et al., 2007) are lost in waste water that may be separated and repurposed to be used as a human food source.

Sarcoplasmic proteins consist of enzymes, globulin, and myoalbumin; with the majority of sarcoplasmic protein functioning as enzymes for cell metabolism. Sarcoplasmic proteins contribute to 25 to 30 percent of fish protein and are soluble in neutral salt solutions (FAO, 2005a). Much of the sarcoplasmic protein is lost when it solubilizes in processing water and is discarded similarly to how whey protein was once discarded during dairy processing. Approximately 30 years ago, whey was considered a by-product of the dairy industry, but this view changed when government regulations on whey disposal were implemented. These governmental regulations forced the dairy industry to conduct research on whey disposal that resulted in it being repurposed as a source of high quality protein. Whey protein can be found in numerous commercial products consumed by both humans and animals (Smithers, 2008). Similar to whey research conducted 30 years ago, this research project aims to develop an easy and efficient protocol for the utilization of an otherwise overlooked protein source.

A preliminary study in our lab indicated that soluble proteins could be extracted from ground silver carp with five steps: dilution, homogenization, centrifugation, filtration, and drying. Insoluble by-products were removed with centrifugation and filtration. Protein in the freeze-dried soluble protein process water accounted for approximately $14 \%$ of total fish protein. The goal of this research was to (a) determine if processing temperature would impact sarcoplasmic protein recovery, (b) characterize 
the extracted soluble protein powder, (c) and compare shelf stability of the soluble protein powder to that of whey protein concentrate. 


\section{References}

1. Arvanitoyannis, I. S. and Kassaveti, A. (2008), Fish industry waste: treatments, environmental impacts, current and potential uses. International Journal of Food Science \& Technology, 43: $726-745$

2. Chen, Y.C., Jaczynski, J. 2007. Protein recovery from rainbow trout (Oncorhynchus mykiss) processing by-products via isoelectric solubilization / precipitation and its gelation properties as affected by functional additives. Journal of Agricultural and Food Chemistry 55:9079-9088.

3. FAO-WHO (2011). Report of the Joint FAO-WHO Expert Consultation on the Risks and Benefits Associated with Fish Consumption. FAO Fisheries and Aquaculture Technical Paper 978.

4. Food and Agriculture Organization of the United Nations (FAO), The State of World Fisheries and Aquaculture, 2014. Rome.

5. Fisheries and Aquaculture topics. Proteins from fish and fish products. Topics Fact Sheets. Text by Lahsen Ababouch. In: FAO Fisheries and Aquaculture Department [online]. Rome. Updated 27 May 2005a. [Cited 31 August 2015].

6. Fisheries and Aquaculture topics. Waste management of fish and fish products. Topics Fact Sheets. Text by Lahsen Ababouch. In: FAO Fisheries and Aquaculture Department [online]. Rome. Updated 27 May 2005b. [Cited 30 August 2015]

7. Gildgerg, A. 2002. Enhancing returns from greater utilization. In: Safety and Quality Issues in Fish Processing. Bremner, H.A. (ed.). Woodhead Publishing Limited. Cambridge (U.K.).

8. Islam, M., Khan, S., \& Tanaka, M. (2004). Waste loading in shrimp and fish processing effluents: Potential source of hazards to the coastal and nearshore environments. Marine Pollution Bulletin, 49, 103-110. 
9. Knap, Renata. "Trends and Factors of Development of the World Consumption of Fish and Fishery Products." Folia Oeconomica Stetinensia 10.1 (2011): 213. ProQuest. Web. 24 Aug. 2015.

10. Ruxton, C. (2011). The benefits of fish consumption. Nutrition Bulletin, 36, 6-19.

11. Smithers, G. (2008). Whey and whey proteins-From 'gutter-to-gold'. International Dairy Journal, (18), 695-704.

12. Wibowo, S., Savant, V., Cherian, G., Savage, T. F., Velazquez, G., \& Torres, J. A. (2007). A Feeding Study to Assess Nutritional Quality and Safety of Surimi Wash Water Proteins Recovered by a Chitosan-Alginate Complex. Journal of Food Science, 72(3). 


\section{Chapter II}

\section{Review of Literature}

\section{Protein Characterization}

According to the Food and Agriculture Organization, global fish consumption has quadrupled over the past 50 years, making it a major source of animal protein in the human diet (FAO, 2005). In general, there are two major types of protein in fish: myofibrillar and sarcoplasmic. Myofibrillar proteins are located in muscle and consist mainly of actin and myosin (FAO, 2005). Sarcoplasmic proteins are water soluble enzymes, globin, and myoalbumin making up 25 to 30 percent of proteins in fish (FAO, 2005). Due to their water soluble nature, sarcoplasmic proteins are lost in surimi and other fish possessing methods when water solubilization occurs (Islam et al., 2004). Surimi is concentrated myofibrillar protein and is the main ingredient of imitation crab meat. During surimi manufacturing, fish fillets are minced and repeatedly rinsed with water to remove slime, scales, blood, viscera lipids, and sarcoplasmic protein. Flavors and preservatives are added to the rinsed fish flesh. After flavoring, the flesh is pressed, packaged, and cooked (FAO, 2005). Large quantities of sarcoplasmic protein are currently discarded in surimi wash water $(\mathrm{FAO}, 2005)$ of which may contain up to $2.3 \%$ protein (Wibowo et al., 2007). Previous research has looked at ways to extract dissolved sarcoplasmic proteins from wash water; therefore, the aim of this review was to evaluate the effectiveness of different recovery strategies and to qualify physical characteristics of recovered sarcoplasmic proteins.

Filtration Units. Membrane filtration is commonly used in the dairy industry for recovery of whey protein (Lin et al., 1995). There have been attempts made to adapt this technology for the recovery of material suspended in surimi processing water. There are several ranges of membrane filtration: microfiltration, ultrafiltration, nanofiltration, and reverse osmosis. Ultra filtration has 
smaller pores compared to microfiltration with actual pore sizes differing by manufacturer. In a study conducted by Stine and colleagues (2012), membrane filtration units were added to surimi wash-water processing streams to recover suspended solids (Stine et al., 2012). Two membranes with pore sizes of $80 \mathrm{kDa}$, were added to the production line. The recovered solids were characterized by determining proximate composition, amino acid and mineral profile, sodium dodecyl sulfate polyacrylamide gel electrophoresis (SDS-PAGE), and storage stability. Proximate composition of the recovered wash water solids was $86.70 \%$ moisture, $0.59 \%$ ash, $1.09 \%$ lipid, and $14.21 \%$ protein, equivalent to $89 \%$ protein, $6 \%$ lipid, and 3\% ash on a dry matter basis. Proximate composition results of the surimi control were $81.12 \%, 0.35 \%$ (1.8\% dry), $0.13 \%$ (0.5\% dry), $18.38 \%$ ( $97 \%$ dry) for moisture, ash, lipid, and protein, respectively. The recovered solids had a lower protein content, but greater moisture and lipid content than surimi, with no significant difference in ash content. The recovered solids contained more essential amino acids when compared to surimi at $45.0 \%$ and $43.7 \%$, respectively. Similar mineral profiles were seen for the recovered solids and surimi. However, the recovered solids contained higher levels of iron, zinc, and copper. The SDS-PAGE revealed that the recovered solids contained low amounts of myosin heavy chain, myosin light chain, and actin while an abundance of low molecular weight protein bands was present. This indicates water insoluble proteins were also suspended in the wash-water (Stine et al., 2012).

The storage study examined proximate composition, SDS-PAGE, whiteness, and lipid oxidation differences for recovered wash water solids and surimi stored at $-20^{\circ} \mathrm{C}$ for 180 days with samples pulled for analysis at days 0,30, 90, and 180 (Stine et al., 2012). No significant changes were detected in the mineral profile and proximate composition over the 180 days. Limited changes were detected in the SDS-PAGE gel of the recovered solids with increased lower molecular bands present at 180 days. As the recovered solids aged, the product darkened which was related to higher iron content. 
Lipid oxidation values tripled in the recovered solids through the 180 day study, with an initial MDA value of approximately $3.8 \mu \mathrm{g} / \mathrm{g}$ and final of around $13.0 \mu \mathrm{g} / \mathrm{g}$. Lipid oxidation increased in the surimi from around 0.5 to $0.7 \mu \mathrm{g} / \mathrm{g}$. The higher lipid oxidation levels of the recovered solids was accredited to the greater lipid content in the sample. Results of this study revealed that proteins from surimi wash water can be recovered using microfiltration and that the resulting recovered solids have a comparable amino acid profile to that of surimi. However, membrane fouling is an issue with ultrafiltration units and methods to overcome this issue were not discussed (Stine et al., 2012).

Lin and others (1995) also used a combination of micro- and ultrafiltration units to recover proteins lost in surimi processing waste water. Filtration units were inserted into the waste water stream of a commercial Pacific whiting surimi operation. Ultrafiltration (30,000 molecular weight limit) was inserted into eight stages throughout the waste streams of the surimi manufacturing process. Two microfiltration units, with combined pore sizes of 50 and $30 \mu$, were installed following the final pressing of washed, minced fish into surimi. Prior to the microfiltration unit, a rotary screen $(100 \mu)$ was inserted. Proximate composition was conducted on the water collected from waste streams and the protein material collected through microfiltration. SDS-PAGE was conducted on the protein material recovered through microfiltration and compared to Pacific Whiting surimi. Results showed that the waste water stream that had the highest protein content was after the first wash at $2.34 \pm 0.25 \%$. This water also had the most non-protein nitrogen, lipid, and ash contents at $0.13 \pm 0.01,0.19 \pm 0.01$, and $0.41 \pm 0.01 \%$, respectively. Waste water collected down the production line had significantly less protein, non-protein nitrogen, lipid, and ash contents. When the proximate composition of the recovered protein was compared to that of surimi, the recovered protein had less protein and more ash. After dewatering, the composition of the recovered protein was $84.5 \pm 0.7$ moisture, $15.0 \pm 0.3$ protein, $0.8 \pm 0.1 \mathrm{lipid}$, and $0.48 \pm 0.4 \%$ ash. On a dry basis that is equivalent to $92 \%, 4.9 \%$, and $2.9 \%$ 
protein, lipid, and ash, respectively. The composition of the final Pacific whiting surimi contained significantly more protein with $80.6 \pm 0.4 \%$ moisture, $18.3 \pm 0.3 \%$ protein, $0.9 \pm 0.1 \%$ lipid, and 0.39 $\pm 0.05 \%$ ash. Approximately $93 \%$ protein, $4.5 \%$ lipid, and $2 \%$ ash and a dry basis. However, the surimi sample contained significantly less $(\mathrm{p}<0.05)$ moisture when compared to the recovered protein. Assuming the recovered protein and surimi do not contain carbohydrates, the protein contents on a dry basis would be approximately 93.42 and $92.14 \%$, respectively. Similar to that of Stine et al., (2012), the SDS-PAGE revealed that myosin and actin lost in the washing process was recovered by the microfiltration unit but not the ultrafiltration unit. Five times more myosin heavy chain was found in the microfiltration unit compared to the ultrafiltration unit. This was related to the microfiltration unit pore size $(50 \mu$ and $30 \mu)$ allowing passage of some soluble proteins with collecting insoluble particles. The protein collected from ultrafiltration contained more low molecular weight bands (between 29 and $45 \mathrm{kDa}$ ) than the microfiltration collected protein. Results from this study indicate the potential use of microfiltration and ultrafiltration for the recovery of protein in wash water with the potential of re-addition to surimi products (Lin et al., 1995).

Coagulating Agents. One method to induce coagulation of suspended solids is by the utilization chitosan's ability to complex with polyanions, such as alginate, pectin, and carrageen (Wibowo et al., 2007). Chitosan is deacetylated chitin, possessing a positive charge (Rinaudo, 2006). Alginate, starch extracted from brown seaweed, is negatively charged (Lee and Mooney, 2012). Interaction between chitosan and alginate causes the formation of a chitosan-alginate cross-linkages and initiates the sedimentation of suspended solids (Lee and Mooney, 2012). In the work by Wibowo and others (2007), chitosan-alginate complex was used for the recovery of soluble proteins in surimi wash-water with the objective of determining the safety and nutritional value of the recovered surimi wash water protein. According to the authors, chitosan has been successfully used to remove 
suspended solids from food processing effluents: cheese whey, poultry waste, tofu whey, etc. Chitosan is deacetylated chitin, carbohydrate found in shells of shell fish and exoskeletons of insects. Surimi wash water was collected at a rotary screening stage. Solids were removed using centrifugation and the wash water was treated with Chitosan-Alginate (Chi-Alg) to coagulate the soluble proteins in the wash water. Chitosan forms complexes with alginate (brown seaweed polysaccharide) and other polyanions, resulting in the coagulation of soluble proteins than can be separated through centrifugation. The coagulated protein was separated through centrifugation and freeze-dried. Proximate composition and amino acid analysis were conducted on the recovered surimi wash water protein and compared to commercial protein meal sources. Proximate composition revealed that the freeze-dried recovered protein had the greatest crude protein content of $73.1 \pm 1.67 \%(68.93 \%$ on wet basis) when compared to herring, menhaden, soybean, and corn gluten meals, with $66.50 \%, 58.86 \%$, $43.21 \%$ and $62.45 \%$ protein on a wet basis, respectively. Among the fish based commercial protein meals, the recovered protein had the greatest carbohydrate content (3.39\%) compared to 1.3 and $2.9 \%$ reported in the herring and menhaden feeds, respectively. Lipid content was similar in surimi wash water $(8.11 \%)$ and the herring and menhaden fish protein meals with 8.0 and $7.8 \%$ lipid, respectively. Surimi wash water protein had greater lipid content compared to soybean (3.1\%) and corn gluten $(1.7 \%)$ meals. Total reported essential amino acid for the surimi wash water protein and four protein meals were $51.8 \%, 35.4 \%$ (herring), 41.4\% (menhaden), $25.4 \%$ (soybean), and $42.8 \%$ (corn gluten), respectively. The amino acid profile revealed the surimi wash water contained greater concentrations of all measured essential amino acids compared to the two fish, soybean, and corn gluten commercial meal sources. The tryptophan content for surimi wash water protein and commercially available meals were not reported. These results indicated the surimi wash water protein is nutrient rich and can be 
compared to commercially available feed-protein sources, in terms of crude protein composition and essential amino acid content (Wibowo et al., 2007).

The nutritional value of protein-peptide hydrolystate (PPH) material derived from hairtail fish was evaluated in the work by Ding and others (2016). Soluble proteins were extracted from minced, headed, scaled, and gutted hairtail fish through the use of 4 steps: dilution (1:5) with distilled water, mixing, centrifugation, and sieve filtration, producing "surimi wash water." Immobilized chymotrypsin-trypin was used to hydrolyze proteins in the filtered supernatant resulting in proteinpeptide hydrolystate material, which was then freeze-dried. The proximate composition was conducted on the surimi wash water, but not on the protein hydrolystate. Analysis of protein components and SDS-PAGE were completed on the surimi wash-water and the protein hydrolystate. An amino acid profile was completed on the recovered PPH and the data was used for the nutritional evaluation. The proximate composition of the surimi wash water revealed the wash-water contained $8.19 \pm 0.10 \mathrm{mg} / \mathrm{ml}$ dry matter, $0.54 \pm 0.01 \mathrm{mg} / \mathrm{ml}(6.5 \%)$ lipid, and $6.68 \pm 0.04 \mathrm{mg} / \mathrm{ml}(81.5 \%)$ crude protein. A large proportion (38.4\%) of protein in the surimi wash-water was from suspended fish particles $(2.61 \pm 0.02$ $\mathrm{mg} / \mathrm{ml}$ ). The small size of the suspended fish particles make protein recovery difficult. Water soluble proteins $(2.26 \pm 0.01 \mathrm{mg} / \mathrm{ml})$ were made up of mostly sarcoplasmic proteins. Flavoring compounds (aldehydes, ketones, alcohols, hydrocarbons, and heterocyclic compounds), oligopeptides and free amino acids, were the main components in the non-protein nitrogen $(1.92 \pm 0.01 \mathrm{mg} / \mathrm{ml})$. There were no differences in crude protein concentration and dry matter between the surimi wash water $(6.78 \pm$ $0.04)$ and the recovered PPH $(6.74 \pm 0.06 \mathrm{mg} / \mathrm{ml})$. The composition of water soluble proteins and nonprotein nitrogen for PPH was $2.81 \pm 0.051$ and $3.94 \pm 0.064 \mathrm{mg} / \mathrm{ml}$. This is greater than the water soluble protein $(2.26 \pm 0.009 \mathrm{mg} / \mathrm{ml})$ and non-protein nitrogen $(1.92 \pm 0.01 \mathrm{mg} / \mathrm{ml})$ identified in the surimi wash-water. This was attributed to the degradation of fish particles during hydrolysis. The 
SDS-PAGE gel, revealed the majority of the proteins in the surimi wash water had molecular weights larger than $20.1 \mathrm{kDa}$. The majority of these proteins were not identified in the recovered proteinpeptide material, with the exception of a protein band at $55.3 \mathrm{kDa}$. This indicated most proteins were degraded to amino acids and small peptides through hydrolysis. The recovered protein-peptide material contained all the essential amino acids needed by humans, which accounted for 44.1 percent of total amino acids. Total amino acid accounted for $78.2 \%$ of the dry matter. High levels of nonessential amino acids were also detected in the recovered protein-peptide material. The FAO/WHO essential amino acid model and the whole egg protein model was used to determine nutritional value. The amino acid score for the recovered protein-peptide material was greater than the $\mathrm{FAO} / \mathrm{WHO}$ essential amino acid model, with methionine + cysteine being the first limiting amino acid. An essential amino acid index of 101.7 (>95), indicated that the recovered protein-peptide material has similar nutritional value to standard whole egg protein. The biological value of the recovered proteinpeptide material (76.7) is greater than that of wheat (67), peanuts (59), and pork (74) with beef having a similar biological value of 76 . However, these calculations do not take the bioavailability of the recovered protein-peptide material into account. These results indicated that the recovered proteinpeptide material extracted from waste water possesses a high nutritional value (Ding et al., 2016).

Characteristics of sarcoplasmic proteins. The purpose of the work done by Lopez-Enriquez and others (2015) was to characterize sarcoplasmic proteins recovered from giant squid mantles with the use of $\mathrm{pH}$ and ionic strength modification. Giant squid was recovered, the mantles were removed and bagged on sight. Sarcoplasmic protein was extracted through homogenization in a 1:3 ratio with water. The slurry was centrifuged and the supernatant sarcoplasmic protein fraction was recovered for analysis. The supernatant was added to $\mathrm{NaCl}(0,0.2$, and $0.5 \mathrm{M})$. Following $\mathrm{pH}$ adjustment to 3.0, 5.0, 7.0, 9.0, or 11.0, the final volume was brought to $25 \mathrm{~mL}$. The solutions were used for SDS-PAGE and 
protein solubility quantification. The effect ionic strength and $\mathrm{pH}$ had on protein solubility was determined by measuring protein content in solution following a 20 min centrifugation. The results exhibited a U-shaped curve, with the minimum and maximum protein solubility present at $\mathrm{pH} 5$ and 11 , respectively. The higher solubility at alkaline $\mathrm{pH}$ was accredited to protein unfolding, hydration, and amino acid ionization (Lopez-Enriquez et. al., 2015). When protein solubility was analyzed with respect to ionic strength there were significant changes $(\mathrm{p}<0.05)$ in protein solubility. At $\mathrm{pH} 3.0$, the solubility decreased $(\mathrm{p}<0.05)$ as ionic strength increased with a minimum solubility at $0.5 \mathrm{M} \mathrm{NaCl}$. These results were attributed to interaction between the negatively charged chloride ion and the positively charged amino acids of the sarcoplasmic proteins, causing sedimentation (Lopez-Enriquez et. al., 2015).

SDS-PAGE was used to evaluate the size of the proteins extracted from giant squid. SDSPAGE revealed squid sarcoplasmic proteins with molecular weights ranging from 30 to $63.7 \mathrm{kDa}$. The most intense bands were located at $37.5,28.2$, and $44.3 \mathrm{kDa}$. No qualitative differences were identified in band intensity as a result of changes in ionic strength or $\mathrm{pH}$. The protein band intensity was lower at $\mathrm{pH} 3$ with $0.5 \mathrm{NaCl}$, reaffirming lower protein solubility under this condition. Because the jumbo squid is a mollusk, the sarcoplasmic protein profile is different from fish species due to differences in enzyme activity. This makes comparisons to fish species difficult, however sarcoplasmic protein in fish fall within the same size range found in the data (Lopez-Enriquez et al., 2015).

Tadpitchayangkoon and others (2012) worked to characterize conformational and structural changes in sarcoplasmic proteins extracted from striped catfish (Pangasius hypophthalmus). Sarcoplasmic protein was extracted through homogenization of minced catfish with three parts water. The slurry was centrifuged and the sarcoplasmic protein containing supernatant was collected and freeze-dried. The freeze-dried sarcoplasmic protein fraction was subjected to three conditions: $\mathrm{pH}$ 
extraction, isoelectric precipitation, and neutralized proteins. These conditions were used in order to better understand the effect of the $\mathrm{pH}$-shift method on conformational changes of proteins. Under extraction $\mathrm{pH}$ conditions, sarcoplasmic protein powder was mixed with water and adjusted to $\mathrm{pH} 3.0$, $5.5,7.0$, or 11.0. Sarcoplasmic proteins subjected to isoelectric precipitation was mixed with water, adjusted to $\mathrm{pH} 3.0$ or 7.0 , and then adjusted to $\mathrm{pH}$ 5.5. Neutralized proteins were mixed with water, adjusted to $\mathrm{pH} 3.0$ or 11.0, followed by $\mathrm{pH}$ adjustment to 5.5 then 7.0. SDS-PAGE was completed on the extracted striped catfish sarcoplasmic protein and solubility testing was completed on the conditioned sarcoplasmic protein (Tadpitchayangkoon et al., 2012).

SDS-PAGE revealed sarcoplasmic protein bands ranging from $36-97 \mathrm{kDa}$, with the bands with the greatest intensity located between 40 and $60 \mathrm{kDa}$ (Tadpitchayangkoon et al., 2012). There was a band present at $205 \mathrm{kDa}$ representing myofibrillar proteins (mainly myosin) however it was deemed insignificant. Solubility of sarcoplasmic protein adjusted to $\mathrm{pH} 7.0$ was $52 \%$, lower than what was recorded for sarcoplasmic proteins extracted from Atlantic mackerel (78\%). The discrepancy was accredited to protein conformational changes as a response to freeze-drying. The solubility decreased with $\mathrm{pH}$, but no difference was seen in solubility when $\mathrm{pH}$ was made alkaline. The isoelectric extracted proteins showed marked decrease in solubility for both $\mathrm{pH} 3.0$ and 11.0, suggesting large amounts of conformational changes in the sarcoplasmic proteins. Neutralization-treatment of sarcoplasmic protein following isoelectric extraction conditions resulted in similar solubility results compared to that of isoelectric extracted proteins. This indicates neutralization did not restore proteins to initial conformations. It was noted that due to different amounts of acids and bases used for $\mathrm{pH}$ adjustment, the ionic strength for solutions were different, however the effect of ionic strength on solubility was arbitrary. Results from this study indicate the solubility of sarcoplasmic protein 
extracted from striped catfish is affected by $\mathrm{pH}$-shift with the acid $\mathrm{pH}$-shift resulting in the lowest protein solubility (Tadpitchayangkoon et al., 2012).

The study by Marcos and others (2010) was designed to determine processing temperature effect on sarcoplasmic proteins in high pressure processing related to beef meat quality. The longissimus dorsi muscles of beef were obtained and vacuum packed 7 days post-mortem. The vacuum sealed muscle samples were high pressure processed for 20 minutes at three different pressures $(200,400$, and $600 \mathrm{MPa})$ and temperatures $\left(10,20\right.$, and $\left.30^{\circ} \mathrm{C}\right)$. Sarcoplasmic proteins were extracted from treated muscle using homogenization with $20 \mathrm{mM}$ Tris, $2 \mathrm{mM}$ EDTA, $4 \mathrm{mM} \mathrm{MgCl}$, and $10 \mathrm{uL} / \mathrm{mL}$ protease inhibitor mix. The slurry was centrifuged and the sarcoplasmic protein containing supernatant was collected for analyses. Protein solubility and SDS-PAGE was completed on the extracted sarcoplasmic proteins.

Protein solubility was analyzed using the Bradford method to determine the concentration of sarcoplasmic protein extracted from the ground muscle. Solubility of the no treatment group was approximately $80 \%$. Solubility decreased with increased pressure and minimal differences were seen with respect to changes in processing temperature. The $400 \mathrm{MPa}$ and $30^{\circ} \mathrm{C}$ was the only treatment that induced a significant lower solubility compared to 10 and $20^{\circ} \mathrm{C}$. SDS-PAGE of the sarcoplasmic protein extracted from non-treated muscle provided 45 protein bands ranging from $14.8-120.6 \mathrm{KDa}$, with the most intense bands located between 30 and $45 \mathrm{KDa}$. This study provides evidence that high pressure processing affects protein solubility and induces protein profile changes which would affect the quality of the product (Marcos et al., 2010).

Water soluble proteins were extracted from surimi wash water through the use of $\mathrm{pH}$ shift and an organic solvent in the work by Bourtoom and others (2008). Surimi wash water was collected from 
the processing streams from threadfin bream surimi production. Precipitation of water soluble protein was done with ethanol and $\mathrm{pH}$ shift using sodium phosphate buffers, with a $\mathrm{pH}$ range of $3.0-6.0$ and temperatures of 4,17 , and $30^{\circ} \mathrm{C}$. The amount of protein precipitated out of the surimi wash was calculated by subtracting the supernatant protein content from the protein content of the initial surimi wash water. Protein precipitation yields were provided and SDS-PAGE was conducted on the surimi wash water.

The greatest concentration of water soluble protein in collected from the initial waste stream was $1.23 \pm 0.08 \mathrm{mg} / \mathrm{ml}$. The SDS-PAGE of the surimi wash water indicated the majority of the soluble proteins have molecular weights in the $23.2-71.6 \mathrm{kDa}$ range with only a few light bands detected below the $23.2 \mathrm{kDa}$ marker. The $\mathrm{pH}$ and temperature condition with the best precipitation of protein was $\mathrm{pH} 3.5$ at $30^{\circ} \mathrm{C}$. In general, as temperature increased, the rate of protein precipitation increased. Protein precipitation increased when the $\mathrm{pH}$ was increased from 3.0 - 3.5, then protein precipitation steadily decreased to $\mathrm{pH}$ 6.0. It was determined that increasing the temperature of processing, increased the amount of protein precipitating out of surimi wash water, which was accredited to protein denaturation at higher temperatures. Solubility of the recovered protein was determined to have a relationship with $\mathrm{pH}$ and temperature. The solubility of the recovered protein increased with $\mathrm{pH}$ and decreased with temperature. Low $\mathrm{pH}$ and higher temperature lead to increased denaturing, leading to lower solubility (Bourtoom et al., 2008).

Ethanol was the organic solvent used to precipitate soluble proteins from surimi wash-water (Bourtoom et al., 2008). Protein precipitation increased with ethanol concentration ranging from approximately $12 \%$ at $10 \mathrm{~g} / 100 \mathrm{~g}$ (ethanol/surimi wash-water) to a max of $64.98 \%$ at $60 \mathrm{~g} / 100 \mathrm{~g}$. However, solubility of the recovered protein was lowest at the $40-60 \mathrm{~g} / 100 \mathrm{~g}$ extraction conditions. Greater solubility was observed in the $10-30 \mathrm{~g} / 100 \mathrm{~g}$ extraction conditions, with $10 \mathrm{~g} / 100 \mathrm{~g}$ having the 
highest solubility. Results from this study provide evidence that altering $\mathrm{pH}$ and organic solvent conditions affect protein precipitation and physical properties of the recovered protein.

Kjærsgård and Jessen (2004) worked to provide patterns of protein oxidation in rainbow trout muscle. Muscle was extracted from freshly thawed rainbow trout loin muscle and from fish left at room temperature for 48 hours. Low-salt-soluble (sarcoplasmic proteins) and high-salt-soluble proteins were extracted through homogenization and centrifugation. 2-dimentional (2D) electrophoresis was used to characterize salt-soluble proteins. The 2D gel of the low and high saltsoluble proteins can be referred to in Figure 1. Staining of the high-salt-soluble gel allowed for the detection of approximately 1500 protein spots, of which some were identified as heavy chain myosin, tropomyosin, and actin. Approximately 2000 protein spots were detected on the gel, however it wasn't possible to identify protein groups from the gel. The results from this study revealed the pattern of protein migration for low and high salt soluble proteins extracted from rainbow trout muscle (Kjærsgård and Jessen, 2004). 
Figure 1: 2D electrophoresis gels of high-salt soluble (1A) and low-salt-soluble (2B) proteins from freshly defrosted rainbow trout.
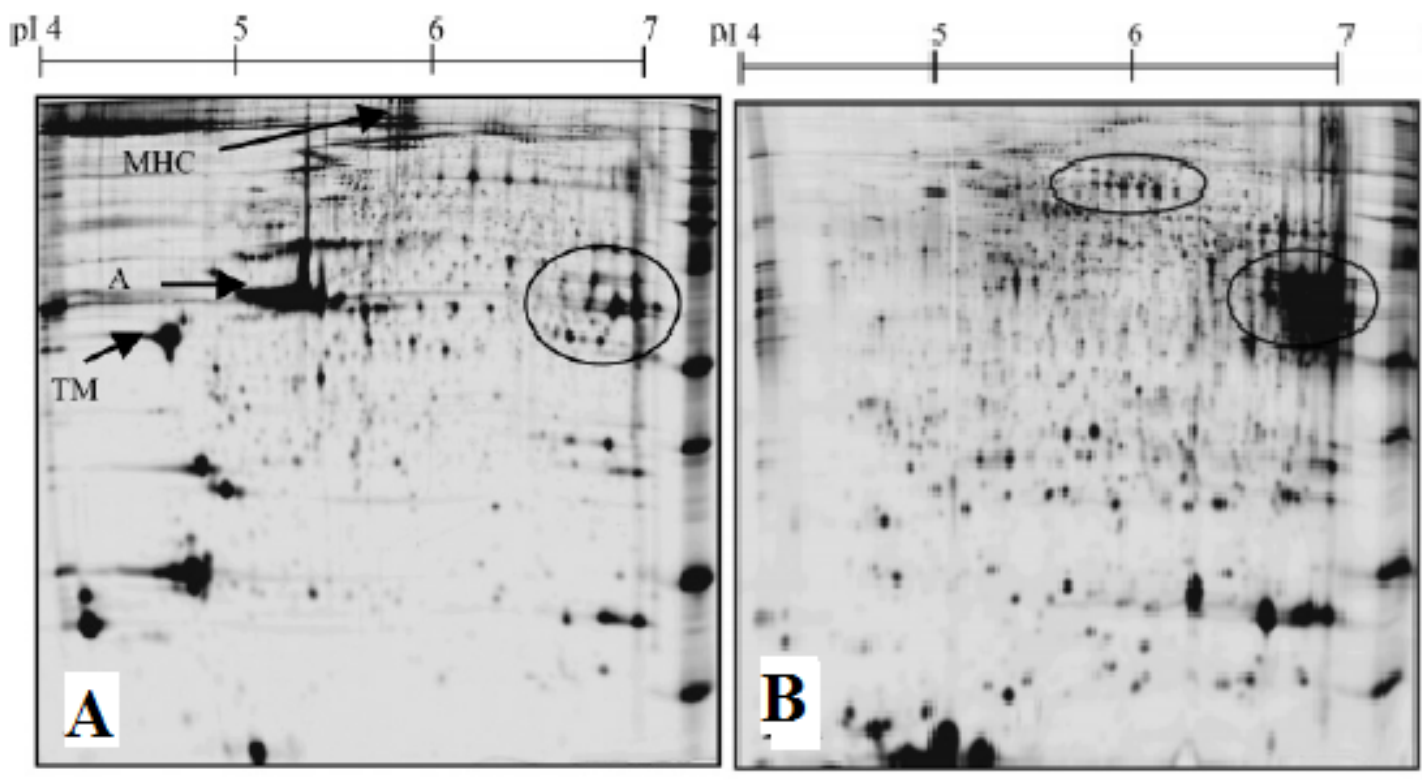

Sourced from Kjærsgård and Jessen (2004) 


\section{Shelf-life analysis}

In the last 50 years, the consumption of aquatic animals has quadrupled (Knap, 2011). One popular aquatic food consumed around the world is surimi. Surimi is concentrated myofibrillar protein produced through the repeated washing of minced fish fillets. During this washing process, blood, slime, lipid, sarcoplasmic proteins, and some myofibrillar proteins are lost (Islam at al., 2004). Sarcoplasmic proteins are soluble in low salt solutions and commonly function as enzymes in cell metabolism. These sarcoplasmic proteins can be recovered from wash water and have potential to be processed into a powder containing high amounts of protein and little lipid. This section of the literature review will evaluate previously published studies investigating the shelf stability of fish fillets and fish sourced protein powders. Due to similarities in physical characteristic between sarcoplasmic and whey proteins, the shelf stability of whey protein concentrates will be discussed, for later comparison.

Tunick and colleagues (2015) aimed to determine changes in physical characteristics and microbial quality of 34 and $80 \%$ protein whey protein concentrate (WPC) stored for 18 months at ambient temperature (approximately $21^{\circ} \mathrm{C}$ ) and $30^{\circ} \mathrm{C}$ in heat sealed bags. Samples were retrieved for analysis at $0,3,6,9,12$, and 18 months. Color, $\mathrm{pH}$, lysine content, water activity, and microbiology plate counts analyses were conducted on the 34 and 80\% protein WPC. Initial lightness values for WPC34 and WPC80 were 89.2 and 87.4, respectively. During the 18 months storage, lightness decreased to 85.3 and 87.3 for WPC34 and WPC80, respectively (Tunick et al., 2015). Changes in final and initial lightness values were not significantly different $(\mathrm{p}>0.05)$. All stored samples became yellower over time, as indicated by increasing $\mathrm{b}^{*}$ values with initial $\mathrm{b}^{*}$ values being 10.8 (WPC34) and 8.9 (WPC80). Storage at ambient temperature resulted in no significant differences $(p>0.05)$ in $b^{*}$ value. Whereas, storage at $30^{\circ} \mathrm{C}$ resulting in significant $(\mathrm{p}<0.05)$ increases in $\mathrm{b}^{*}$ value to 
approximately 15.9 (WPC34) and 16.7 (WPC80). This color change was explained by hydrolysis of lactose, increasing reactive groups for non-enzymatic browning reaction with lysine.

Measures of $\mathrm{pH}$ of WPC34 resulted in no significant differences $(\mathrm{p}>0.05)$ in $\mathrm{pH}$ with initial values ranging from 6.37 - 6.47 and final (18 month) values ranging from 6.30 - 6.40 (Tunick et al., 2015). Storage of WPC80 resulted in significant changes $(\mathrm{p}<0.05)$ in $\mathrm{pH}$ of $6.23-6.33$ initially to $5.80-6.00$ at 18 months. These changes were attributed to the high free fatty acid content in WPC80 resulting in decreased pH (Tunick et al., 2015). Lysine content was higher in WPC80 initially compared to WPC34 at $5.4-5.5$ and $4.3-4.9 \%$, respectively. Lysine content decreased significantly $(\mathrm{p}<0.05)$ to $0.9-1.5 \%$ (WPC34) and $2.6-4.2$ (WPC80). This decrease was attributed to Millard (browning) reaction (Tunick et al., 2015). The water activity of WPC34 stored under ambient conditions was initially 0.28 and increased to 0.31 at 18 months. An increase in water activity was also observed in WPC 80 from 0.22 initially to 0.25 at 18 months. Occurrence of protein degradation releases bound water, cause water activity to increase. The low water activity of WPC resulted in limited microbial and no coliforms detected. The maximum bacteria and yeast/mold counts were 3.78 and $3.82 \log _{10} \mathrm{CFU} / \mathrm{g}$, respectively. The results of this study indicated WPC loses physical properties overtime with the magnitude of degradation being dependent on storage environment and initial product (Tunick et al., 2015).

The shelf stability of material recovered through membrane filtration was analyzed in the work by Stine et al., (2012). Membrane filtration was used for the recovery of solids suspended in surimi wash water. Upon receiving the membrane concentrate from the production line, an initial ( 0 day) sample was recovered. The remaining was stored in whirl pack bag at $-20^{\circ} \mathrm{C}$ for 180 days. Differences in proximate composition, SDS-PAGE band, whiteness, and lipid oxidation were examined at 0,30 , 90, and 180 days (Stine et al., 2012). No significant changes were detected in composition over the 
180 days. Limited changes were detected in the SDS-PAGE gel of the membrane concentrate with increased lower molecular bands present at 180 days, indicating the occurrence of proteolysis (Stine et al., 2012). As the membrane concentrate aged the product slightly darkened, with initial whiteness values of approximately 58 declining to approximately 56 at 180 days. The darker color was related to the higher iron content in the membrane concentrate (Stine et al., 2012). Lipid oxidation values tripled in the membrane concentrate through the 180 day study, with an initial MDA value of approximately $3.8 \mu \mathrm{g} / \mathrm{g}$ and final of around $13.0 \mu \mathrm{g} / \mathrm{g}$. The significant increase $(\mathrm{p}<0.05)$ in lipid oxidation levels with time in the membrane concentrate was accredited to the high lipid content $(1.09 \% \pm 0.27)$ in the sample compared to the $0.13 \% \pm 0.04$ found in surimi (Stine et al., 2012). Results from this study suggested storage of surimi wash water membrane concentrate at $-20^{\circ} \mathrm{C}$ resulted in minimal changes to quality measures such as composition, whiteness, and SDS-PAGE band patterns. There were however, significant increases $(\mathrm{p}<0.05)$ in lipid oxidation were identified (Stine et al., 2012).

The storage stability of protein-based films derived from round scad, a relatively small fish typically used as bait, was analyzed in the work by Artharn et al. (2009). Once received, round scad were filleted and fillets were minced. The minced flesh was homogenized in three parts water. Glycerol was added to a level of $50 \%$ of the protein and the solution was agitated for 30 minutes at room temperature. The resulting solution was filtered using commercial nylon sheets and then the films were cast. Film cast was accomplished by drying $4.0 \mathrm{~g}$ of the solution under blowing for 12 hours at room temp on silicon dishes before being dried to $50 \%$ relative humidity in an environmental chamber (Artharn et al., 2009). The resulting films were pealed from silicon plates and placed in a desiccator. Samples were collected at week $0,1,2,4,6$, and 8 for analysis. Storage stability of film was accessed through measurement of color, film solubility, and protein solubility. Additionally, mackerel meat powder was produced by the drying and powdering of mackerel fillets. The mackerel 
powder $(20 \mathrm{~g})$ was placed in cylindrical cups and covered with round scad films in order to determine the films effectiveness for extending shelf-stability of dried fish powder (Artharn et al., 2009). Samples were stored at $28-30^{\circ} \mathrm{C}$ for 21 days with samples being removed every three days. TBARS values were determined for the dried mackerel powder covered with round scad films (Artharn et al., 2009).

Solubility of round scad film increased approximately $10 \%$ in the first two weeks of storage, from $40 \%$ initially to $50 \%$ at week 2 . The rise in film solubility was accredited to protein-protein interactions leading to glycerol molecules to be embedded in the film matrix. (Artharn et al., 2009) This limited the amount of glycerol able to leach out of the film (Artharn et al., 2009). Protein solubility decreased through the first two weeks, from $10 \%$ to approximately $6 \%$. Occurrence of crosslinking between proteins in the first two weeks would result in the larger molecular weight molecules and increasing aggregation (Artharn et al., 2009). Following week two, film solubility and protein solubility remained relatively constant with only minor undulations. Over eight weeks the film darkened, this was evidenced by the decrease in L-value (approximately $81-79$ ), however the decrease was not significant $(p>0.05)$. In the first two weeks, $a^{*}$-value decreased from approximately -2.1 to -3.5 . Following week two, a ${ }^{*}$-values increased to -0.1 at week 8 . Throughout the 8 week study, b-values steadily increased from approximately 7 to 38 . The steady increase of $b^{*}$-value indicated the occurrence of non-enzymatic browning reaction (Maillard reaction), causing an increase in yellowness (Artharn et al., 2009).

TBARS values and color measures were conducted on the mackerel powder stored with and without a film cover. For all mackerel powder samples, TBARS values increased to a maximum at day nine of storage, followed by a decrease until day 15 , when TBARS values remained relatively constant. The mackerel powder stored without round scad films had a higher maximum 
(approximately $160 \mathrm{mg} \mathrm{MDA} / \mathrm{kg}$ sample) compared to the covered mackerel powder (approximately $110 \mathrm{mg} \mathrm{MDA} / \mathrm{kg}$ sample). The lower TBARS value indicate that the film acted as an oxygen barrier reducing the extent of lipid oxidation (Artharn et al., 2009). Similar to TBARS results, the mackerel powder stored without a film cover had the highest increase in b-values and a-values from approximately $18-28$ and $2.8-7.5$ respectively. Initial b-values and a-values of the covered mackerel powder are similar to the uncovered however the values at day 21 were lower at approximately 24 and 6, respectively. Increases in b-value is an indication of yellowing due to the Maillard reaction. Higher reported b-values for the uncovered mackerel powder could be contributed to by higher lipid oxidation increasing the non-enzymatic browning reaction rate (Artharn et al., 2009). The results of this study provide evidence of the shelf stability of films derived from round scab and their potential use as an oxygen barrier.

Kachele et al. (2017) assessed vacuum packing on shelf life stability of silver carp fillets. Fresh silver carp were received and filleted. Silver carp fillets were cut into 2-3 cm cubes and vacuumed packed under two pressures: 30 and $50 \mathrm{Kpa}$. A control group was stored without vacuum packing and for the purpose of this review is the group which will be concentrated on. All three groups were stored at $4^{\circ} \mathrm{C}$ for two weeks with samples removed for analysis at $0,2,4,6,8,10,12$, and 14 days.

Color parameters, $\mathrm{pH}$, and total viable count counts were conducted. $\mathrm{L}^{*}$-values of the control samples decreases throughout the study, from approximately 6.5 (day 0) to 4.5 (day 14). A significant decline $(\mathrm{p}<0.05)$ in $\mathrm{a}^{*}$-value was also seen in the control group with 3 unit reduction from approximately $46-43$. The decrease in redness value in control groups could be an indication of oxidation of hemoglobin, producing a brown color (Kachele et al., 2017). There was a significant increase $(\mathrm{p}<0.05)$ in $\mathrm{b}^{*}$-values when comparing day $0(-2)$ to day $14(1.0)$. The control resulted in the greatest change in $\mathrm{pH}$, from approximately $6.5-7.5$. Although, a net increase in $\mathrm{pH}$ was seen over the 
14 days, the $\mathrm{pH}$ slightly decreased until day 4 followed by a steady increase to day 14 . The initial drop in $\mathrm{pH}$ was accredited to lactic acid production through glycolysis (Kachele et al., 2017). After lactic acid production ceased, the $\mathrm{pH}$ increased indicating accumulation of alkaline compounds produced by bacteria. The initial microbial load of the control samples were $3.53 \log _{10}$ and increased to $9.56 \log _{10}$ at day 14. The initial microbial load is dependent on water temperature, production practices, and transportation conditions. Initial microbial loads can vary from $2-6 \log _{10}$, indicating the relatively high quality of the selected silver carp fillets. The maximum acceptable microbial load for fresh water fish is $7.0 \log _{10}$, indicating the shelf-life of the control fillets were 9 days. The results from this study provide needed data on the shelf-life of silver carp fillets stored under refrigeration conditions $\left(4^{\circ} \mathrm{C}\right)$ (Kachele et al., 2017).

The aim of this review was to (a) investigate previous research on nutritional and physical characteristics of protein powders derived from fish and other meat sources and (b) review the shelf stability of protein powders. It can be concluded that powders derived from fish by-product sources have similar nutritional quality to that of the final product (fillets of surimi). Physical properties of powders are dependent on the source they are derived from and the method of extraction. Review of shelf life studies indicate protein powders have potential to remain shelf stable for long periods of time however, storage conditions and occurrence of the Millard reaction must be taken into account. Further research is needed on the direct comparisons of fish derived protein powders with more common powders, such as whey protein concentrate. 


\section{References:}

1. Artharn, A., Prodpran, T., \& Benjakul, S. (2009). Round scad protein-based film: Storage stability and its effectiveness for shelf-life extension of dried fish powder. Food Science and Technology, 42, 1238-1244.

2. Bourtoom, T., Chinnan, M., Jantawat, P., \& Sanguandeekul, R. (2009). Recovery and characterization of proteins precipitated from surimi wash-water. LWT - Food Science and Technology, 42(2), 599-605. doi:10.1016/j.lwt.2008.09.001

3. Micro-filtration, ultra-filtration and nano-filtration. (n.d.). Retrieved May 24, 2017, from https://condorchem.com/en/micro-filtration-ultra-filtration-nano-filtration/

4. Ding, H., Li, D., Wei, X., Huang, Y., Cui, S., Xie, H., \& Zhou, T. (2016). Protein-peptide nutritional material prepared from surimi wash-water using immobilized chymotrypsin-trypsin. Journal of the Science of Food and Agriculture J. Sci. Food Agric. doi:10.1002/jsfa.7969

5. Fisheries and Aquaculture topics. Proteins from fish and fish products. Topics Fact Sheets. Text by Lahsen Ababouch. In: FAO Fisheries and Aquaculture Department [online]. Rome. Updated 27 May 2005. [Cited 31 August 2015].

6. Fisheries and Aquaculture topics. Waste management of fish and fish products. Topics Fact Sheets. Text by Lahsen Ababouch. In: FAO Fisheries and Aquaculture Department [online]. Rome. Updated 27 May 2005

7. Guenneugues, P., \& Morrissey, M. T. (2005). Surimi resources. In J. W. Park (Ed.), Surimi and Surimi Seafood (pp. 3-29). Boca Raton, FL: CRC Press.

8. Islam, M., Khan, S., \& Tanaka, M. (2004). Waste loading in shrimp and fish processing effluents: Potential source of hazards to the coastal and nearshore environments. Marine Pollution Bulletin, 49, 103-110. 
9. Kachele, R., Zhang, M., Gao, Z., \& Adhikari, B. (2017). Effect of vacuum packaging on the shelf-life of silver carp ( Hypophthalmichthys molitrix ) fillets stored at $4{ }^{\circ} \mathrm{C}$. LWT - Food Science and Technology, 80, 163-168.

10. Kjærsgård, I., \& Jessen, F. (2004). Two-Dimensional Gel Electrophoresis Detection of Protein Oxidation in Fresh and Tainted Rainbow Trout Muscle. Journal of Agricultural and Food Chemistry, 52(23), 7101-7107.

11. Knap, Renata. "Trends and Factors of Development of the World Consumption of Fish and Fishery Products." Folia Oeconomica Stetinensia 10.1 (2011): 213. ProQuest. Web. 24 Aug. 2015.

12. Lee, K., \& Mooney, D. (2012). Alginate: Properties and biomedical applications. Progress in Polymer Science, 106-126.

13. Lin, T. M., Park, J. W., \& Morrissey, M. T. (1995). Recovered Protein and Reconditioned Water from Surimi Processing Waste. Journal of Food Science, 60(1), 4-9. doi:10.1111/j.13652621.1995.tb05594.x

14. Lopez-Enriquez, R. L., Ocano-Higuera, V. M., Torres-Arreola, W., Ezquerra-Brauer, J. M., \& Marquez-Rios, E. (2015). Chemical and Functional Characterization of Sarcoplasmic Proteins from Giant Squid (Dosidicus gigas) Mantle. Journal of Chemistry, 2015, 1-10.

15. Marcos, B., Kerry, J. P., \& Mullen, A. M. (2010). High pressure induced changes on sarcoplasmic protein fraction and quality indicators. Meat Science, 85(1), 115-120.

16. Rinaudo, M. (2006). Chitin and Chitosan — Properties and Applications. Progress in Polymer Science, 31(7), 603-632. 
17. Stine, J., Pedersen, L., Smiley, S., \& Bechtel, P. (2012). Recovery And Utilization Of Protein Derived From Surimi Wash-Water. Journal of Food Quality, 35(1), 43-50. doi:10.1111/j.17454557.2011.00424.x

18. Tadpitchayangkoon, P., Park, J. W., Mayer, S. G., \& Yongsawatdigul, J. (2010). Structural Changes and Dynamic Rheological Properties of Sarcoplasmic Proteins Subjected to pH-Shift Method. Journal of Agricultural and Food Chemistry, 58(7), 4241-4249.

19. Tunick, M. H., Thomas-Gahring, A., Van Hekken, D. L., Iandola, S. K., Singh, M., Qi, P. X., Ukuku, D. O., Mukhopadhyay, S., Onwulata, C. I., and Tomasula, P. M. (2016). Physical and chemical changes in whey protein concentrate stored at elevated temperature and humidity. Journal of Dairy Science, 99(3), 2372-2383. doi:10.3168/jds.2015-10256

20. Wibowo, S., Savant, V., Cherian, G., Savage, T. F., Velazquez, G., \& Torres, J. A. (2007). A Feeding Study to Assess Nutritional Quality and Safety of Surimi Wash Water Proteins Recovered by a Chitosan-Alginate Complex. Journal of Food Science, 72(3). doi:10.1111/j.1750-3841.2007.00291.x 


\section{Chapter III}

Characterization of soluble proteins recovered from silver carp: Impact of protein recovery processing temperature on nutritional quality and physical characteristics of silver carp soluble protein powders

Derek Warren, Ilgin Paker, Jacek Jaczynski, Janet Tou, Kristen E. Matak*

West Virginia University, Animal and Nutritional Sciences, Morgantown, WV 26506, USA.

*Corresponding Author:

Dr. Kristen Matak

Phone: 304-293-2231

Email: kristen.matak@mail.wvu.edu

Choice of journal section where article should appear: 


\begin{abstract}
During surimi processing sarcoplasmic proteins, water soluble protein making up $25-30 \%$ of all proteins in fish, are lost in wash water. There is potential for the development of a simple method to reclaim and repurpose this protein from surimi wash water. The objective of this study was to evaluate the composition of sarcoplasmic protein powders separated from silver carp at varying solubilization temperatures $\left(4,20\right.$, and $\left.40^{\circ} \mathrm{C}\right)$. Protein powder was recovered from ground silver carp by dilution, homogenization, centrifugation, filtration, heating, centrifugation, and drying. Proximate composition, recovery yields, mineral analysis, fatty acid analysis, and amino acid analysis were verified. The proximate composition (dry weight basis) of the protein powders averaged $82.42 \%$ protein, $3.25 \%$ lipid and $14.50 \%$ ash, with no significant differences between treatments $(p>0.05)$. A significant difference $(\mathrm{p}<0.05)$ in protein recovery yields was observed between the $4^{\circ} \mathrm{C}(11.05 \% \pm 0.46)$ and $20^{\circ} \mathrm{C}(12.45 \% \pm 0.16)$ powders. There were no significant differences $(\mathrm{p}>0.05)$ in lipid recovery yields and mineral composition between treatments yet significant differences $(p<0.05)$ were identified in fatty acid and amino acid profiles. Total saturated (SFAs) and monounsaturated fatty acids (MUFAs) were greatest in the $4^{\circ} \mathrm{C}$ powder $\left(32 \%\right.$ and $29 \%$, respectively) and lowest in the $40^{\circ} \mathrm{C}$ powder. Polyunsaturated fatty acids (PUFAs) displayed a reverse trend, with the greatest PUFA concentration in the $40^{\circ} \mathrm{C}(25 \%)$ powder and the lowest in the $4^{\circ} \mathrm{C}$ powder. The amino acid profile revealed that tryptophan and valine were the only essential amino acids that displayed significant differences in concentration $(\mathrm{p}<0.05)$, with the $20^{\circ} \mathrm{C}$ powder containing the greatest of both. When compared to the $\mathrm{FAO} / \mathrm{WHO} / \mathrm{UNO}$ amino acid requirements the protein powders met all adult requirements; however lysine was the only amino acid found in sufficient amounts to meet the infant amino acid requirement. Sodium dodecyl sulfate polyacrylamide gel electrophoresis (SDS-PAGE), 2-
\end{abstract}


D electrophoresis, and solubility was used to further characterize the protein powder. SDS-PAGE revealed high amounts of low and medium molecular weight (MW) proteins $(10-15$ and $25-50 \mathrm{kDa}$, respectively). Results from 2-D electrophoresis indicated that the low MW proteins possess a relative neutral isoelectric point relative to that of the medium MW proteins. Similar results were seen with WPC 80 . The protein powder was significantly less soluble $(\mathrm{p}<0.05)$ than WPC 80 at every $\mathrm{pH}$ tested (pH $3.0-11.0)$. Similar solubility tendencies were identified when ionic strength $(0.0-1.1 \mathrm{I})$ was shifted resulting in solubility of the protein powder being significantly less $(\mathrm{p}<0.05)$ than WPC 80. Results from this study indicate soluble protein powders derived from silver carp are nutrient rich, the resulting protein powder has physical characteristics resembling whey protein concentrate and changes in process temperature had limited effects on protein powder composition.

KEYWORDS: protein powder, sarcoplasmic protein, protein recovery, amino acid, solubility 


\section{$\underline{\text { Introduction }}$}

In the last 50 years, global consumption of fish has nearly doubled (FAO, 2014). Natural caught fish production plateaued in the 1980's, with aquaculture fish production making up the difference (FAO, 2014). Growth of global aquaculture production has decreased by $3.3 \%$ in the past 20 years and with the population steadily increasing at $1.6 \%$ each year, suggesting current resources need to be used more efficiently (FAO, 2014). One way this could be done is with better utilization of less-desirable fish and fish processing by-products. Surimi are fish products that consist of concentrated myofibrillar protein. During surimi processing, ground fish fillets are washed multiple times in order to remove blood, viscera, slime, and unwanted flavors (FAO, 2005). Solid by-products (heads, tails, etc.) have found uses in fish meals for animal feeds, biofuels, natural pigments, cosmetics, and nutrition supplement (Arvanitoyannis \& Kassaveti, 2006). During the washing process, sarcoplasmic proteins solubilize in wash water and are lost. Sarcoplasmic proteins are a group of proteins consisting of water soluble enzymes, globulin, and myoalbumin. Their concentration is species dependent, but make up $25-30 \%$ of protein in fish (FAO, 2005). There is an open opportunity for the development of an extraction and dehydration method conducive for the collection of soluble proteins suspended in wash water. The resulting protein material has commercial potential depending on the retention of nutritional quality and desirable physical characteristics.

Strategies such as filtration and microfiltration have been used to recover these soluble proteins as well as myofibrillar proteins lost in the washing process. Stine et al. (2012) used membrane filtration for the recovery of approximately $80 \%$ of proteins contained in surimi processing wash water with the membrane functioning properly for 7-8 $\mathrm{h}$ periods. Ultrafiltration was utilized by Lin et al. (1995), in the recovery of proteins in surimi wash water. Recovery of suspended protein was successful, but the fouling of membranes was continually an issue. Bourtoom et al. (2008) recovered 
water soluble proteins through $\mathrm{pH}$ shift and organic acid precipitation from surimi wash water; however, the maximum recovery yields from both methods were approximately $65 \%$ of soluble protein. Chitosan-alginate complexes were used to recover soluble protein from surimi wash water, whereas the initial monetary investment for this method was high (Wibowo et. al (2007). Ding et al. (2016) successfully utilized centrifugation and freeze-drying for the concentration of protein-peptide nutritional material from surimi wash water.

Analysis of proximate composition of material recovered from surimi processing waste streams indicated moisture making up that majority of the recovered solid at $86.70 \%$, followed by protein at $14.21 \%$ (Stine et al., 2012). Equivalent to approximately $89.42 \%$ protein when moisture is removed (Stine et al., 2012). Wibowo and others (2007) freeze-dried suspended solids recovered from surimi waste water revealing a protein composition of $68.93 \%$. The recovered protein material contained greater concentrations of essential amino acids when compared to four commercially available protein meals. Analysis of protein size via SDS-PAGE indicated that recovered solids contain larger amounts of low molecular weight proteins (Stine et al., 2012; Lin et al., 1995). Previous research provides evidence of high solubility of sarcoplasmic proteins (Marcos et al., 2010; Bourtoom et al., 2008). However, to our knowledge no comparisons have been made to whey protein concentrate, which is a commonly used food additive and protein source (Smithers, 2008).

Preliminary work in our lab showed that sarcoplasmic protein can be extracted from silver carp with five steps: dilution, homogenization, centrifugation, filtration, and drying. The resulting sarcoplasmic protein powder had a protein recovery yield of $14 \%$ and consisted of $14 \%$ lipid and $63 \%$ protein (dry basis). The purpose of this study was to determine if heat treatment $\left(4,20,40^{\circ} \mathrm{C}\right)$ would improve the composition and recovery yields of sarcoplasmic protein powder extracted from ground 
silver carp and analyze physical and chemical properties of sarcoplasmic protein powder produced from silver carp and to compare it to commercially available $80 \%$ whey protein concentrate. 


\section{Methods:}

\section{Fish Preparation:}

Eighty-three pounds of headed and gutted silver carp were received on ice through overnight mail. The tail and all fins were removed with a band saw (Hobart, Model \# 27-1174-894), the fish were cut into steaks and then cooled at $4^{\circ} \mathrm{C}$ overnight. The next day the cut fish was twice coarse ground with a meat grinder (Hobart, Model \# 4146 SS). The coarse paste was spread $7.5 \mathrm{~cm}$ thick and stored at $-20^{\circ} \mathrm{C}$ until crust frozen (about one h). The crust frozen paste was finely ground and portioned into bags $(500 \mathrm{~g})$ which were vacuum-sealed. Bags of fish paste were stored for 24 hours at $20^{\circ} \mathrm{C}$ and then transferred to storage at $-80^{\circ} \mathrm{C}$.

Prior to the protein recovery process, frozen fish was thawed for $48 \mathrm{~h}$ at $4{ }^{\circ} \mathrm{C}$. Thawed paste was mixed with $1500 \mathrm{~mL}$ of deionized and distilled water (1:3 ratio) and homogenized on ice for $10 \mathrm{~min}$ in a $3000 \mathrm{ml}$ beaker. The homogenized fish mixture was transferred to centrifuge tubes and centrifuged at $10,000 \mathrm{G}$ for $15 \mathrm{~min}$ at $4^{\circ} \mathrm{C}$. After centrifugation, the liquid supernatant (protein process water) was filtered using cheese cloth to remove insoluble components (i.e., myofibrillar protein, bone, skin, etc.) and lipids which were discarded. The filtered protein process water was maintained at $4^{\circ} \mathrm{C}$ for 15 min or heated until $20^{\circ} \mathrm{C}$ or $40^{\circ} \mathrm{C}$ was reached (approximately $15 \mathrm{~min}$ ). The protein process water was then centrifuged at $10,000 \mathrm{G}$ for $15 \mathrm{~min}$ in a centrifuge chilled or heated to the respective temperatures. The supernatant was again filtered to separate out any remaining lipid. The protein process water was transferred to freezer cups, stored at $-20^{\circ} \mathrm{C}$ until frozen and then freeze-dried (VirTis, Model \#35L).

\section{Proximate Composition and Recovery Yield:}

Proximate composition analysis (moisture, ash, crude protein and lipid) was determined on the initial fish paste and the powdered soluble protein recovered at 4,20 and $40^{\circ} \mathrm{C}$. 
The oven drying method was used to determine the moisture content of the samples. Samples measuring $2 \mathrm{~g}$ were placed in a $105^{\circ} \mathrm{C}$ oven overnight. The following formula was used to determine the moisture content (ASTM, 1993);

Moisture content $(\mathrm{MC})=\frac{\text { Initial weight-oven dried weight }}{\text { Initial weight }} \times 100$ of total mass

Samples that had been oven dried for the moisture content assay were placed into a muffle furnace for $24 \mathrm{~h}$ at $550{ }^{\circ} \mathrm{C}$ (Otto et al.). The ash content was calculated using the following formula (ASTM, 1993);

Ash content $(\mathrm{AC})=\frac{\text { Dried weight }}{\text { Initial weight }} \times 100$ of total mass

The Kjeldahl assay was used to determine crude protein content. There were three steps to this assay: sample digestion, distillation, and titration. The number of moles of base was subtracted from the number of moles of acid used in the titration to give the moles of nitrogen. Once the number of moles of nitrogen in the sample was determined, it was multiplied by 14.0067 (nitrogen's atomic mass) to convert it into grams of nitrogen. Grams of protein was calculated by multiplying the number of grams of nitrogen by 6.25 . Protein recovery yield was calculated using the following equation (Chen and Jaczynski, 2007);

Protein Recovery Yield $(\mathrm{g})=\frac{\text { Recovered crude protein }}{\text { Protein in inital sample }}$

The Soxhelt extraction method was used to measure the lipid content of the samples. A 1 gram aliquot of each sample was placed into a petroleum ether extraction for $15 \mathrm{~h}$ with a drip rate of 10 $\mathrm{mL} / \mathrm{min}$ (Otto et al.). The following equations were used to calculate total lipid content and lipid recovery yields, representatively (AOAC, 1995, Chen and Jaczynski, 2007): 
Lipid Content $(\%)=\frac{(w t . o f \text { dried sample \& weigh boat })-(\text { wt.of weigh boat })}{\text { wt.of initial sample }}$

$$
\text { Lipid Recovery Yield }(\mathrm{g})=\frac{\text { Recovered lipid }}{\text { Lipid in inital sample }}
$$

\section{Amino Acid Analysis:}

Amino acid analysis was conducted on the initial fish homogenate and the powdered sarcoplasmic proteins recovered at 4,20 , and $40^{\circ} \mathrm{C}$. Samples were sent to the University of MissouriColumbia for analysis. All analyses were conducted according to the Association of Official Analytical Chemists methods (AOAC, 1995; AOAC 982.30 E). Hydrochloric acid (6 N) was used for acid hydrolysis for $24 \mathrm{~h}$ at $110^{\circ} \mathrm{C}$. Hydrolyzed samples were oxidized with performic acid at $0-5^{\circ} \mathrm{C}$ overnight. Acid hydrolysis with $\mathrm{HCl}$ was repeated and followed by alkaline hydrolysis for $22 \mathrm{~h}$ with 4.2 N NaOH at $110^{\circ} \mathrm{C}$. Following hydrolysis, a Beckman Amino Acid Analyzer (model 6300, Beckman Coulter, Inc., Fullerton CA) was used to quantify amino acid profiles using step gradients of sodium citrate buffers with the cation exchange postcolumn ninhydrin derivation method.

\section{Fatty Acid Analysis:}

Fatty acid analysis was conducted on the initial fish homogenate and the powdered sarcoplasmic proteins recovered at 4,20 , and $40^{\circ} \mathrm{C}$. Samples were sent to the University of MissouriColumbia for analysis. All analyses were conducted according to methods described by AOAC (1995). Acidic hydrolysis was used for fatty acid extraction (AOAC 996.06). Pyrogallic acid was added to minimized fatty acid oxidative degradation. Ether was used for fatty acid extraction followed by methylation to fatty acid methyl esters (FAMEs) using boron trifluoride and methanol. Capillary gas chromatography was used for FAMEs quantification using triglyceride, triundecanoin (C11:0) as an internal standard. Samples were analyzed using a gas-liquid chromatographer (Agilent Technologies, 
Santa Clara, Calif., U.S.A., Model 7890A) equipped with a 7683B series Injector. Helium was the carrier gas used, at a flow rate of $0.75 \mathrm{ml}$.

After separation at $100^{\circ} \mathrm{C}$ for $4 \mathrm{~min}$, the temperature was increased to $240^{\circ} \mathrm{C}$ at $3^{\circ} \mathrm{C} / \mathrm{min}$ for 15 minutes. Detector and injector temperatures of 285 and $225^{\circ} \mathrm{C}$, respectively, were used. Comparison of retention times to references were used to determine peaks. Individual fatty acids were summed to determine total fat and were expressed as their triglyceride equivalents (Simmons et al., 2011)

\section{Mineral Profile Analysis:}

Mineral profile analysis was conducted on the powdered sarcoplasmic proteins recovered at 4, 20 , and $40^{\circ} \mathrm{C}$ and the initial fish homogenate. All glassware and crucibles used for analysis were kept in a $10 \% \mathrm{HCl}$ solution overnight. An ashing oven (Fisher Scientific, Pittsburg, PA) was used to ash samples $(1.5 \mathrm{~g})$ at $550^{\circ} \mathrm{C}$ overnight. Ashed samples were dissolved in $1.5 \mathrm{~mL}$ of nitric acid. After samples were dissolved, distilled, deionized water was added to the crucible and the solution was filtered through Whatman no. 1 filter paper into a $25 \mathrm{~mL}$ volumetric flask. The solution was diluted to $25 \mathrm{~mL}$ with distilled, deionized water. An inductively coupled plasma optical emission spectrometer

(model P400; Perkin-Elmer, Shelton, CT) was used to measure sample calcium (Ca), phosphorous (P), Magnesium (Mg), iron ( $\mathrm{Fe})$, and sodium $(\mathrm{Na})$ concentrations (AOAC, 1995).

\section{Sodium dodcecyl sulphate-polyacrylimide gel electrophoresis (SDS-PAGE):}

SDS-PAGE was conducted on the tempered sarcoplasmic protein powder $\left(4^{\circ} \mathrm{C}\right)$, initial fish homogenate and whey protein concentrate. Samples containing $40 \mu \mathrm{g}$ of protein were loaded into three 15\% Tris-HCl separating gels (Ready Gels for electrophoresis, Bio Rad Laboratories, Hercules, CA). Gels were run at a constant $200 \mathrm{~V}$ and a 15-20mA current using a PowerPac Basic power supply (Bio Rad Laboratories, Hercules, CA) in a Mini-Protein 3 Cell (Bio Rad Laboratories, Hercules, CA). Next, 
gels were stained with Coomasie staining solution and placed on a plate shaker (LAB-LINE

Instruments, Melrose Park, IL) for 1 hour. Gels were destained using Coomasie destain for two hours and the solution was replaced every 30 minutes. Protein band intensities were measured using an Odyssey Model 9120 (Li-COR, Lincoln, NE).

\section{2-Dimentional (2-D) Electrophoresis:}

All materials and methods for 2-D electrophoresis were adapted from methods provided by the ReadyPrep 2-D Starter Kit (Bio Rad Laboratories, Hercules, CA). 2-D electrophoresis was conducted on the tempered soluble protein powders $\left(4^{\circ} \mathrm{C}\right)$, the freeze-dried initial homogenate, and $80 \%$ whey protein concentrate (WPC 80). WPC80 contain milk whey protein concentrate and soy lecithin was purchased from a food wholesaler (bulkfoods.com).

Isoelectric focusing (IEF):

All samples were mixed with rehydration buffer (Bio Rad Laboratories, Hercules, CA), resulting in sample protein concentrations of $1.35 \mathrm{mg} / \mathrm{ml}$. ReadyStrip IPG strips, $\mathrm{pH}$ 4-7 (Bio Rad Laboratories, Hercules, CA) were rehydrated in $125 \mu \mathrm{l}$ of the prepared sample solution and overlaid with mineral oil. Rehydrating IPG strips were allowed to sit overnight or 12-16 hrs. Following rehydration, IPG strips were transferred to the IEF tray containing dampened gel wicks and overlaid with mineral oil. IPG strips were focused in 3 steps according to methods provided in the ReadyPrep Starter kit (Bio Rad Laboratories, Hercules, CA). Briefly, strips were focused for $20 \mathrm{~min}$ at 250 volts in a linear fashion, followed by $2 \mathrm{~h}$ at 4,000 volts in a linear fashion, and finishing with 4,000 volts for 10,000 V-hr in a rapid fashion. Focusing was completed in 5 hours. Once focusing was completed, IPG strips were transferred to a clean rehydration tray and stored at $-80^{\circ} \mathrm{C}$ until SDS-PAGE occurred. All measures were repeated in duplicate. 
SDS-PAGE:

Focused IPG strips were allowed to thaw for $10 \mathrm{~min}$ before equilibration occurred. A milliliter of equilibrium buffer \#1 (Bio Rad Laboratories, Hercules, CA) was added to the IPG strips. The strips were placed on a plate shaker (LAB-LINE Instruments, Melrose Park, IL) for 10 min then the equilibrium buffer was poured off and equilibrium buffer \#2 was added. After 10 min on the plate shaker, the buffer was decanted. The equilibrated IPG strips were dipped in $1 \mathrm{X}$ Tris/glycine/SDS running buffer (Bio Rad Laboratories, Hercules, CA) then placed in the well of the pre-cast SDSPAGE gel (Bio Rad Laboratories, Hercules, CA) containing liquid agarose. Once the agarose solidified, electrophoresis was conducted using a Mini-Protein 3 Cell (Bio Rad Laboratories, Hercules, CA) at 200 Volts, constant for 40-45 min. Once electrophoresis was completed, gels were stained in Coomassie staining solution for 45 min on a plate shaker (LAB-LINE Instruments, Melrose Park, IL). Gels were destained using Coomasie destain solution for two hours, replacing destain solution every 30 min. Gels were photographed using an iPhone 5s (Apple, Cupertino, CA). Gel photographs were analyzed with the UN-SCAN-IT (Silk Scientific, Orem, UT) computer program. All measures were duplicated.

\section{Ionic Strength Solubility:}

Solubility measures were conducted on WPC 80 and the soluble protein powder $\left(4^{\circ} \mathrm{C}\right)$. Sodium chloride, calcium chloride, and potassium chloride solutions with ionic strengths of $0,0.1,0.3,0.5$, 0.7, 0.9, and 1.1 I were used. Using a blender (Waring Pro, Torrington, CT), $0.25 \mathrm{~g}$ of sample was homogenized with $25 \mathrm{ml}$ of salt solutions for one min. After homogenization, $10 \mathrm{ml}$ of the sample solution was centrifuged at $21^{\circ} \mathrm{C}$ for $5 \mathrm{~min}$ at $1,000 \times \mathrm{G}$. The supernatant was decanted and protein concentration was determined using the Bradford method. Briefly, $100 \mu$ of each sample and $5 \mathrm{ml}$ of Quick Start Bradford Dye Reagants (Bio Rad Laboratories, Hercules, CA) were incubated at room 
temperature for $5 \mathrm{~min}$. After incubation, the absorbance was measured using a spectrophotometer (Model DU 530, Beckman Coulter, Inc., Fullerton CA) at $595 \mathrm{~nm}$. Protein concentration was quantified using a Quick Start Bradford Protein Assay Kit (Bio Rad Laboratories, Hercules, CA). All measures were repeated in triplicate.

\section{pH Solubility:}

Solubility of recovered soluble protein powder $\left(4^{\circ} \mathrm{C}\right)$ and $80 \%$ whey protein concentration was

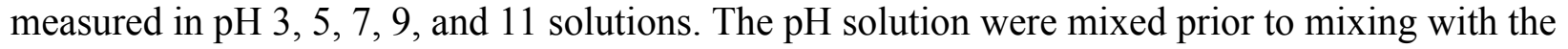
protein powders using concentrated $\mathrm{HCl}$ and $1 \mathrm{M} \mathrm{NaOH}$. The protein powders $(0.25 \mathrm{~g})$ were mixed with $25 \mathrm{ml}$ of the $\mathrm{pH}$ solutions. Minor $\mathrm{pH}$ adjustments were corrected using diluted $\mathrm{HCl}$ and $0.10 \mathrm{M}$ $\mathrm{NaOH}$. The protein powders and $\mathrm{pH}$ solutions were homogenized for $1 \mathrm{~min}$ in a blender (Waring Pro, Torrington, CT). Following homogenization, $10 \mathrm{ml}$ of the protein solution was transferred to centrifuge tubes and centrifuged at $1,000 \times \mathrm{G}$ for $5 \mathrm{~min}$ at $4^{\circ} \mathrm{C}$. The supernatant was decanted and saved for determination of protein concentration using the Bradford method. Briefly, $100 \mu$ of each sample solution was mixed with $5 \mathrm{ml}$ of Quick Start Bradford Dye Reagent (Bio Rad Laboratories, Hercules, $\mathrm{CA}$ ) and incubated for $5 \mathrm{~min}$ at room temperature. Following incubation, the absorbance of each sample at $595 \mathrm{~nm}$ was measured using a spectrophotometer (Model DU 530, Beckman Coulter, Inc., Fullerton CA). The Quick Start Protein Assay Kit (Bio Rad Laboratories, Hercules, CA) was used to quantify the sample protein concentrations. All measures were completed in triplicate.

\section{Statistical Analysis:}

Powder recovery was replicated three times at 4,20 , and $40^{\circ} \mathrm{C}$ and all analyses were completed in triplicate for each protein powder replicate and initial fish homogenate sample. Proximate composition, yields, amino acid profile, fatty acid profile, and mineral profile was conducted with all 
three separation temperatures and comparisons were made to the initial fish homogenate. SDS-PAGE, 2-D electrophoresis, and solubility were conducted only on the soluble protein powder extracted at $4^{\circ} \mathrm{C}$ and compared to WPC80. SAS JMP Pro version 11 (JMP 1998-2012) was used for all analyses. One-way analysis of variance with Tukey-Kramer's honestly significant differences and linear regression tests were used to identify significant differences $(\alpha=0.05)$.

\section{$\underline{\text { Results and Discussion }}$}

\section{Proximate Composition:}

The proximate composition of the sarcoplasmic protein recovered at varying temperatures and the protein and lipid recovery yields are shown in Table 1. There were no significant differences in proximate composition among recovered protein portion $(\mathrm{p}>0.05)$ although, numerical differences were observed. The proximate composition of the freeze-dried initial homogenate contained $49.57 \% \pm 2.45$ nitrogen and $48.45 \% \pm 2.45$ lipid. There were no significant differences in protein powder proximate composition as a function of recovery temperatures $(p<0.05)$, with average nitrogen and lipid concentrations averaging $82.42 \% \pm 1.21$ and $3.26 \% \pm 0.88$, respectively. Other studies (Wibowo et al., 2007; Lin et al., 1995) reported similar results. The work by Wibowo and others (2007) utilized chitosan-alginate complex for soluble protein recovery in surimi wash water. Wibowo and others (2007) reported nitrogen and lipid percentages of $77.5 \%$ and $9.12 \%$, respectively. Lin et al. (1995) used a rotary screen incorporated with a microfiltration unit to remove proteins lost in surimi wash water. They reported protein, fat, and ash compositions of 96.03, 5.12, and 3.07 percent, respectively. Variations in proximate composition in both studies are likely due to differences in starting material composition and recovery methods.

There were no differences in lipid recovery yields between the temperature treatments; however there were significant differences $(\mathrm{p}<0.05)$ in protein recovery yields. When protein was 
recovered at $20^{\circ} \mathrm{C}$ the protein yield was greater than when compared to protein recovered at $4^{\circ} \mathrm{C}(\mathrm{p}<$ $0.05)$. As previously stated, $25-30 \%$ of protein in fish is sarcoplasmic protein. With protein recovery ranging from $11.05 \% \pm 0.46$ to $12.45 \% \pm 0.16$ of total protein indicates that approximately $36.82-$ $49.80 \%$ of the water soluble proteins were recovered, leaving unrecovered soluble proteins remaining in the centrifuge pellet. To increase the total protein recovery yield, extraction of sarcoplasmic proteins could be paired with $\mathrm{pH}$-shift processes like isoelectric solubilization and precipitation (ISP) that would also recover the myofibrillar proteins (Paker et al., 2013).

\section{Mineral Profile:}

There were no significant differences $(\mathrm{p}>0.05)$ in mineral profiles of the protein powders recovered at different processing temperatures (Table 2); however, the mineral profiles of the protein powders were significantly different from the initial fish homogenate. With the exception of calcium, all other minerals were found in greater concentrations in the protein powders compared to the initial fish homogenate. The greater levels of calcium found in the initial fish homogenate can be accounted for by the presence of bones in the initial homogenate.

According to the American Academy of Family Physicians, the most common nutritional deficiency worldwide is iron deficiency anemia. The recommended dietary allowance (RDA) for iron in adult males and females is $8 \mathrm{mg} /$ day (OSU, 2016). The greatest level of iron found in the recovered protein powder was $7.16 \mathrm{mg} / 100 \mathrm{~g}$ sample, which is equivalent to $2.00 \mathrm{mg} / \mathrm{serving}(28 \mathrm{~g})$ and would account for more than $25 \%$ of the RDA for an adults iron. The RDA for magnesium is 420 and 320 $\mathrm{mg} / \mathrm{day}$ for adult males and females, respectively. Magnesium was found in the greatest concentration at $190.86 \mathrm{mg} / 100 \mathrm{~g}$ sample $\left(40^{\circ} \mathrm{C} \mathrm{SPP}\right)$ or $53.44 \mathrm{mg} /$ serving $(28 \mathrm{~g})$. It is unlikely the protein powder would be consumed in sufficient amounts to reach the RDA for either males or females. There is no multivitamin or mineral supplement containing $100 \%$ of the daily requirement of magnesium (OSU, 
2016) and according to a review article by Roasanoff and others (2014), approximately half (48\%) of the United States population was deficient in magnesium in $2005-2006$. Magnesium deficiency has been correlated with numerous diseases such as, type 2 diabetes, hypertension, asthma, colon cancer among others (Roasanoff et. al., 2014).

Fatty Acid Profile:

There were significant differences in the fatty acid profiles of the recovered protein powders (Table 3) as a function of solubilization temperature. Total saturated fatty acids (SFAs) and monounsaturated fatty acids (MUFAs) concentrations were greatest in the $4^{\circ} \mathrm{C}$ protein powder at 32 and 29\%, respectively. The lowest SFAs (29\%) and MUFAs (19\%) concentrations were in the $40^{\circ} \mathrm{C}$ protein powder. A reserve trend was identified in the concentrations of polyunsaturated fatty acids (PUFAs) with the greatest concentration of PUFAs in the $40^{\circ} \mathrm{C}$ protein powder and the lowest in the $4^{\circ} \mathrm{C}$ sarcoplasmic powder $\left(14^{\circ} \mathrm{C}\right)$. Linear regression (Figure 1) shows that concentration of SFAs and MUFAs decreases as temperature increases, while PUFAs concentrations increase with temperature $(\mathrm{p}<0.05)$ indicating that protein solubilization temperature does have an effect on lipid composition in sarcoplasmic protein powder.

Consumption of $\omega-3$ fatty acids is related to benefits in cardiovascular health due to their antiinflammatory nature. The greatest concentrations of eicosapentaenoic acid (EPA, 20:5, $\omega-3)$ and decosahexaenoic acid (DHA, 22:6, $\omega-3$ ) were identified in the $40^{\circ} \mathrm{C}$ protein powder at 8.31 and $9.03 \%$, respectively, which are greater than reported concentrations of EPA $(1.78 \%)$ and DHA $(2.25 \%)$ in fresh silver carp fillets (Naseri et al., 2010). The EPA and DHA concentrations for silver carp fillets were expected to be similar to that of the initial fish homogenate used in the current study, however they were up to 3 times lower (Naseri et al., 2010). Greater concentrations of SFAs and PUFAs and lower concentrations of MUFAs were identified in the recovered protein powder (Table 3) when 
compared to the reported fatty acid profile for silver carp fillets at $26.18 \%, 15.09 \%$, and $52.14 \%$ respectively (Naseri et al., 2010). These differences are likely due to seasonal differences in silver carp composition and processing techniques.

Amino Acid Profile:

The amino acid profile of the recovered protein powders were compared to the initial fish homogenate, WPC 80 and the FAO/WHO/UNU amino acid requirements for adults and infants (Table 4). When comparing the amino acid profile between the protein powders recovered at different processing temperatures, processing temperature had little effect on essential amino acid (EAA) composition. Tryptophan and valine were the only essential amino acids that had significantly different $(\mathrm{p}<0.05)$ compositions with the highest concentration of both identified in the $20^{\circ} \mathrm{C}$ protein powder. No significant differences $(\mathrm{p}<0.05)$ were identified in the non-essential amino acids for the three processing temperatures.

With the exception to histidine and tryptophan, the protein powders had a lower EAA composition when compared to the initial fish homogenate with total EAA compositions of approximately 439.41 and $515.34 \mathrm{mg} / \mathrm{g}$ protein, respectively. The decrease in EAA content can be explained by the loss of the myofibrillar protein through the sarcoplasmic protein extraction process, evident by the loss of the 200kDa band in the SDS-PAGE gel (Figure 2). When the total EAA content of the sarcoplasmic protein powder is compared to that of WPC 80 (549.7 $\mathrm{mg} / \mathrm{g}$ protein), a larger deficit can be seen. Whey protein concentrates are high in most essential amino acids, but value is placed on the high concentrations of the branch chain amino acids (leucine, isoleucine, and valine) for their role in energy metabolism in muscle (Marshall, 2004). The Leucine and isoleucine content was greater in WPC 80 than in the sarcoplasmic protein powders. Valine content was also greater in WPC 80 , but the difference is relatively small ( $15 \%$ of the WPC 80 valine content). Arginine, histidine, and 
phenylalanine + tyrosine were found in greater concentrations in the sarcoplasmic protein powder than in the WPC 80. These results indicate both sarcoplasmic protein powders and WPC 80 are rich sources of essential amino acids; however, this data does not take bioavailability into consideration.

Bioavailability of the sarcoplasmic protein would need to be studied to ensure the high levels of amino acids it contains can be utilized by the body.

SDS-PAGE

The array of proteins contained in the silver carp initial homogenate and recovered protein powder and WPC is shown in Figure 2. Differences in protein band patterns are apparent between the fish homogenate and protein powders. Protein bands in the initial homogenate sample are evenly dispersed along the gel with the bands with the highest pixel density located at approximately $200 \mathrm{kDa}$ and between 30 and $50 \mathrm{kDa}$. The proteins in the protein powder are dispersed more centrally between 20 and $65 \mathrm{kDa}$, with bands of low weight proteins located between 10 and $15 \mathrm{kDa}$. SDS-PAGE of WPC revealed additional low molecular weight protein bands between 10 and $20 \mathrm{kDa}$. Similar results have been previously seen in giant squid sarcoplasmic protein, striped catfish sarcoplasmic protein, and beef longissimus dorsi muscle sarcoplasmic protein. Protein bands ranging from 30 to $63.7 \mathrm{kDa}$ were seen in sarcoplasmic proteins extracted from giant squid, with the highest pixel density located at 37.5, 28.2 and 44.3 kDa (Lopez-Enriquez et al., 2015). Tadpitchayangkoon and others (2012) identified protein bands in striped catfish sarcoplasmic protein sample ranging from $40-97 \mathrm{kDa}$, with the highest pixel density bands located between 40 and $60 \mathrm{kDa}$. SDS-PAGE characterization of sarcoplasmic proteins extracted from beef longissimus dorsi muscle revealed 45 protein bands ranging from $14.8-120.6 \mathrm{kDa}$ (Marcos et al., 2010). The work by Marcos and others (2010) had the greatest range of separation compared to the other studies. This could be due to the fact it was the only study characterizing sarcoplasmic protein from a mammal instead of a fish or mollusk. 
Common myofibrillar proteins, actin and myosin heavy chain have molecular weights of approximately 40 and $200 \mathrm{kDa}$, respectively (Stine et al., 2012). Bands of high pixel density are identified at these points in the initial fish homogenate; however, the band at $40 \mathrm{kDa}$ in the protein powder is easily distinguished but has much lower pixel density and the band at $200 \mathrm{kDa}$ is barely visible. These results indicate that this protein recovery process extracted mainly the water or saline soluble sarcoplasmic protein and smaller myofibrillar proteins (actin) while leaving large myofibrillar proteins (myosin heavy chain) in the centrifuged pellet. However, different proteins of the same approximate size will appear in a single band, indicating more detailed proteomic work could be done to determine the identity of these bands.

\section{2-D Electrophoresis}

By using 2-dimensional (2-D) electrophoresis, proteins are first separated by isoelectric point (the $\mathrm{pH}$ at which a protein has a net charge of zero), followed by separation by molecular weight. 2-D electrophoresis gels of silver carp derived soluble protein powder, $80 \%$ whey protein concentrate, and initial silver carp homogenate is shown in Figure 3. Electrophoresis of sarcoplasmic protein powder (A) revealed protein spots mainly on the neutral (right) side of the gel, indicating that the isoelectric point of proteins contained in the protein powder were near neutral. 2-D electrophoresis of low-salt soluble proteins extracted from rainbow trout using the same $\mathrm{pH}$ 4-7 IEF strips revealed separation of protein spots throughout the $\mathrm{pH}$ range however, more protein spots were identified as the $\mathrm{pH}$ approached neutral (Kjærsgård \& Jessen, 2004). Differences in extraction methods, species, protein concentrations, and electrophoresis methods could explain differences in results.

Comparison of sarcoplasmic protein powder electrophoresis gels to $80 \%$ whey protein concentrate (B) and initial silver carp homogenate (C) revealed protein pattern differences. As stated previously, proteins in recovered protein powder remained close to neutral $\mathrm{pH}$. Proteins in the whey 
protein concentrate were widely dispersed throughout the $\mathrm{pH}$ range and size range. With most spots falling on the $\mathrm{pH} 4$ and small molecular weight range. Smearing can be seen on the gel which is most likely due to the carbohydrate content of the whey protein concentrate. 2-D electrophoresis of initial silver carp homogenate revealed relatively equal dispersion throughout the $\mathrm{pH}$ and molecular weight range. The initial homogenate contained muscle and connective tissue that wasn't present in the extracted sarcoplasmic protein sample, producing the increased variety of protein spots. Heavy stain smearing of the gel can be explained by the high lipid content, approximately 50 percent, of the initial fish homogenate sample. Low repeatability is a common limitation with 2-D electrophoresis and stain spearing can result from lipids and carbohydrates in the sample.

\section{Protein Solubility}

Protein solubility is a valuable functional property that is tied to other properties such as emulsification and foaming. Solubility is a function of both solution $\mathrm{pH}$ and ionic strength. Solutions with differing $\mathrm{pH}$ will result in various stages of protein unfolding, leading to solubility differences. Solutions with various ionic strengths have concentration differences of charged ions, which will interact with oppositely charged amino acid groups. Increased interactions of charged ions would decrease water interactions, leading to precipitation of proteins (Lopez-Enriquez et. al., 2015).

Solubility of the recovered protein powder and $80 \%$ whey protein concentrate in 0 to 1.1 ionic strength solutions of $\mathrm{KCl}, \mathrm{NaCl}$, and $\mathrm{CaCl}_{2}$ were reported in Figure 4. When WPC 80 is compared to the recovered powder at similar salt solutions, WPC 80 was significantly $(\mathrm{p}<0.05)$ more soluble than the recovered protein powder. Soy lecithin was commercially added to the purchased WPC 80. Soy lecithin is a commonly used emulsifier due to its amphiphilic nature. Composed of phospholipids, soy lecithin contains both hydrophilic and hydrophobic regions. This enables compounds that would otherwise be insoluble in water, to solubilize (Colbert, 1998). Additionally, WPC 80 contained greater 
numbers of low molecular weight proteins bands when ran on SDS-PAGE gels indicating that proteins of lower molecular weight solubilize more readily. Minimal changes were seen in the solubility of WPC 80 in different ionic strength solutions. However, when WPC 80 was dissolved in the $\mathrm{NaCl}$ solution it had significantly greater solubility when compared to solutions of $\mathrm{CaCl}_{2}$ and $\mathrm{KCl}$. Krishnamurthy and others (1996) reported $\mathrm{CaCl}_{2}$ solutions of low ionic strength provided and inhibitory effect of protein solubility. However, as ionic strength increased, protein solubility returned to levels similar to what was observed in $\mathrm{NaCl}$ solutions (Krishnamurthy et al., 1996). Solution ionic strength played a greater role in solubility of the recovered protein powder with the $1.1 \mathrm{I} \mathrm{NaCl}$ solution resulting in the greatest protein solubility. Lopez-Enriquez et al., (2015) found solubility within varying $\mathrm{NaCl}$ concentration solutions is dependent on $\mathrm{pH}$. At neutral $\mathrm{pH}$, a $0.2 \mathrm{M} \mathrm{NaCl}$ solution produced the highest protein solubility, followed by 0.5 and $0.0 \mathrm{M} \mathrm{NaCl}$. Result differences could be due to differences in extraction methods. In contrast to our methods, Lopez-Enriquez and others (2015) completed protein solubility immediately after sarcoplasmic protein extraction, without freezedrying. Freeze-drying has potential to induce protein denaturation, resulting in changes to protein solubility.

Protein solubility of recovered protein powder and WPC in respect to changes in $\mathrm{pH}$ can be seen in Figure 6. Protein solubility of the recovered protein powder ranged from $83.10-83.61 \%$ with minimum and maximum values occurring and $\mathrm{pH} 7$ and $\mathrm{pH} 5$, respectively. WPC 80 protein solubility ranged from $84.29-85.79 \%$. Greater solubility of WPC 80 could be accredited to the addition of soy lecithin to the purchased product. Solubility of WPC 80 was lowest at $\mathrm{pH} 11$ and greatest at $\mathrm{pH} 3$. These results indicate protein solubility of WPC and recovered protein powder decrease as $\mathrm{pH}$ is raised, with WPC having a greater decrease in solubility due to $\mathrm{pH}$. An opposite trend is seen when referring to the work by Lopez Enriquez et al., (2015). Lopez-Enriquez and others (2015) produced a 
U-shaped graph when solubility was measured with changes in $\mathrm{pH}$, with a minimum and maximum at pH 5 and 11, respectively. Results from this study produced a relatively linear figure with a minimum and maximum for protein powder at $\mathrm{pH} 7$ and 5, respectively. These differences in results could be explained by differences in protein powder extraction methods. Freeze-drying was used to reduce the protein containing supernatant to a powder. Lopez-Enriquez, and others (2015) did not utilize freeze drying to concentrate the supernatant. Freeze-drying is a harsh environment resulting in protein denaturation, leading to changes in solubility.

\section{$\underline{\text { Conclusion }}$}

In conclusion, the results of this study indicate sarcoplasmic protein powders extracted from silver carp are nutrient rich. Changes in processing temperatures had little impact on nutritional composition of the protein powder. Utilization of sarcoplasmic protein extraction technologies could be one way to reduce waste in the surimi industry while producing a commercially viable product. Results from this study provide no indication of the bioavailability and shelf-life of the sarcoplasmic protein powder. Future studies will determine bioavailability and shelf life of protein powders, as well as look at strategies to scale to commercial production. 


\section{$\underline{\text { References }}$}

1. Arvanitoyannis, I. S. and Kassaveti, A. (2008), Fish industry waste: treatments, environmental impacts, current and potential uses. International Journal of Food Science \& Technology, 43: $726-745$

2. Association of Official Analytical Chemists (AOAC). 1995. Official Methods of Analysis, 16th ed.; Association of Official Analytical Chemists: Washington, DC.

3. ASTM D 2974-87 Standard Test Methods for Moisture, Ash, and Organic Matter of Peat and Other Organic Soils. 1993. Retrieved from; http://urf.lib.msu.edu/1990s/1993/930331.pdf

4. Arvanitoyannis, I. S. and Kassaveti, A. (2008), Fish industry waste: treatments, environmental impacts, current and potential uses. International Journal of Food Science \& Technology, 43: 726-745

5. Bourtoom, T., Chinnan, M., Jantawat, P., \& Sanguandeekul, R. (2009). Recovery and characterization of proteins precipitated from surimi wash-water. LWT - Food Science and Technology, 42(2), 599-605.

6. Chen, Y.C., Jaczynski, J. 2007. Protein recovery from rainbow trout (Oncorhynchus mykiss) processing by-products via isoelectric solubilization / precipitation and its gelation properties as affected by functional additives. Journal of Agricultural and Food Chemistry, 55, 9079-9088.

9. Colbert L.B., (1998). Lecithins tailored to your emulsification needs. Cereal FoodsWorld, 43, 686-688. 
10. Fisheries and Aquaculture topics. Proteins from fish and fish products. Topics Fact Sheets. Text by Lahsen Ababouch. In: FAO Fisheries and Aquaculture Department [online]. Rome. Updated 27 May 2005.

11. Fisheries and Aquaculture topics. Waste management of fish and fish products. Topics Fact Sheets. Text by Lahsen Ababouch. In: FAO Fisheries and Aquaculture Department [online]. Rome. Updated 27 May 2005.

12. FAO-WHO (2011). Report of the Joint FAO-WHO Expert Consultation on the Risks and Benefits Associated with Fish Consumption. FAO Fisheries and Aquaculture Technical Paper 978.

13. FAO/WHO/UNU. (1985). Energy and protein requirements. Report of joint FAO/WHO/UNU expert consultant. Technical report series no. 724. Geneva: World Health Organization.

14. Food and Agriculture Organization of the United Nations (FAO), The State of World Fisheries and Aquaculture, 2014. Rome.

15. Islam, M., Khan, S., \& Tanaka, M. (2004). Waste loading in shrimp and fish processing effluents: Potential source of hazards to the coastal and nearshore environments. Marine Pollution Bulletin, 49, 103-110.

16. Killip, S., Bennett, J., \& Chambers, M. (2007). Iron Deficiency Anemia. Am Fam Physicians, $75(5), 671-678$

17. Kjærsgård, I., \& Jessen, F. (2004). Two-Dimensional Gel Electrophoresis Detection of Protein Oxidation in Fresh and Tainted Rainbow Trout Muscle. Journal of Agricultural and Food Chemistry, 52(23), 7101-7107. 
18. Krishnamurthy, G., Chang, H., Hultin, H. O., Feng, Y., Srinivasan, S., \& Kelleher, S. D. (1996). Solubility of Chicken Breast Muscle Proteins in Solutions of Low Ionic Strength. Journal of Agricultural and Food Chemistry, 44(2), 408-415. doi:10.1021/jf950152r

19. Lin, T. M., Park, J. W., \& Morrissey, M. T. (1995). Recovered Protein and Reconditioned Water from Surimi Processing Waste. Journal of Food Science, 60(1), 4-9.

20. Marcos, B., Kerry, J. P., \& Mullen, A. M. (2010). High pressure induced changes on sarcoplasmic protein fraction and quality indicators. Meat Science, 85(1), 115-120.

21. Marshall, K. (2004). Therapeutic Applications of Whey Protein. Alternative Medicine Review, $9(2), 136-156$.

22. Micronutrients for Older Adults. (2016). Retrieved October 21, 2016, from http://lpi.oregonstate.edu/mic/life-stages/older-adults

23. Naseri, M., Rezaei, M., Moieni, S., Hosseni, H., \& Eskandari, S. (2010). Effect of different precooking methods on chemical composition and lipid damage of silver carp (Hypophthalmichthys molitrix) muscle. International Journal of Food Science \& Technology, 45(10), 1973-1979.

24. Otto, R. A., Beamer, S., Jaczynski, J., Matak, K. E. Survival of Listeria innocua after Isoelectric Solubilization/Precipitation with Acetic and Citric Acids Manuscript.

25. Life Stages. (2016, July 06). Retrieved April 05, 2017, from http://lpi.oregonstate.edu/mic/life-stages

26. Paker, I., Beamer, S., Jaczynski, J., \& Matak, K. E. (2013). Compositional Characteristics of Materials Recovered from Headed Gutted Silver Carp (Hypophthalmichthys molitrix) by Isoelectric Solubilization and Precipitation Using Organic Acids. Journal of Food Science, $78(3)$. 
27. Rosanoff, A., Weaver, C. M., \& Rude, R. K. (2012). Suboptimal magnesium status in the United States: are the health consequences underestimated? Nutrition Reviews, 70(3), 153-164.

28. Ruxton, C. (2011). The benefits of fish consumption. Nutrition Bulletin, 36, 6-19.

29. Smithers, G. (2008). Whey and whey proteins-From 'gutter-to-gold'. International Dairy Journal, (18), 695-704.

30. Tadpitchayangkoon, P., Park, J. W., Mayer, S. G., \& Yongsawatdigul, J. (2010). Structural Changes and Dynamic Rheological Properties of Sarcoplasmic Proteins Subjected to pH-Shift Method. Journal of Agricultural and Food Chemistry, 58(7), 4241-4249.

31. Weichselbaum, E., Coe, S., Buttriss, J., \& Stanner, S. (2013). Fish in the diet: A review. Nutrition Bulletin, 38(2), 128-177.

32. Simmons, C. A., Turk P., Beamer, S., Jaczynski, J., Semmens, K., Matak, K. E. 2011. The Effect of a Flaxseed Oil-Enhanced Diet on the Product Quality of Farmed Brook Trout (Salvelinus fontinalis) Fillets Journal of Food Science. S1-S6.

33. Stine, J., Pedersen, L., Smiley, S., \& Bechtel, P. (2012). Recovery And Utilization Of Protein Derived From Surimi Wash-Water. Journal of Food Quality, 35(1), 43-50.

34. Taskaya, L., Y.C. Chen, S. Beamer, Tou, J. C. and J. Jaczynski. 2009. Compositional Characteristics of Materials Recovered from Whole Gutted Silver Carp (Hypophthalmichthysmolitrix) Using Isoelectric Solubilization/Precipitation. J. Agric. Food Chem 57 (10); 4259-4266

35. Tunick, M. H., Thomas-Gahring, A., Van Hekken, D. L., Iandola, S. K., Singh, M., Qi, P. X., Ukuku, D. O., Mukhopadhyay, S., Onwulata, C. I., and Tomasula, P. M. (2016). Physical and chemical changes in whey protein concentrate stored at elevated temperature and humidity. Journal of Dairy Science, 99(3), 2372-2383. doi:10.3168/jds.2015-10256 
36. Wibowo, S., Savant, V., Cherian, G., Savage, T. F., Velazquez, G., \& Torres, J. A. (2007). A Feeding Study to Assess Nutritional Quality and Safety of Surimi Wash Water Proteins Recovered by a Chitosan-Alginate Complex. Journal of Food Science, 72(3). 


\section{Figures and Tables}

Table 1: Proximate composition (\% dry weight basis) and recovery yields of recovered protein powder recovered at 4,20 , and $40^{\circ} \mathrm{C}$

\begin{tabular}{|c|c|c|c|c|c|}
\hline Sample & Nitrogen (\%) & Lipid (\%) & $\operatorname{Ash}(\%)$ & $\begin{array}{c}\text { Protein } \\
\text { Recovery } \\
\text { Yield (\%) } \\
\end{array}$ & $\begin{array}{c}\text { Lipid } \\
\text { Recovery } \\
\text { Yield (\%) } \\
\end{array}$ \\
\hline IH & $49.57 \pm 5.58$ & $48.45 \pm 2.45$ & $6.71 \pm 1.58$ & NA & NA \\
\hline $4^{\circ} \mathrm{CPP}$ & $81.66 \pm 1.13$ & $3.98 \pm 0.66$ & $14.14 \pm 0.69$ & $11.05 \pm 0.46^{\mathrm{B}}$ & $0.61 \pm 0.06$ \\
\hline $20^{\circ} \mathrm{C} P P$ & $82.67 \pm 1.14$ & $3.18 \pm 0.79$ & $14.70 \pm 0.13$ & $12.45 \pm 0.16^{\mathrm{A}}$ & $0.56 \pm 0.06$ \\
\hline $40^{\circ} \mathrm{C} \mathrm{PP}$ & $82.93 \pm 1.09$ & $2.61 \pm 0.62$ & $14.67 \pm 0.46$ & $11.84 \pm 0.25^{\mathrm{AB}}$ & $0.46 \pm 0.12$ \\
\hline
\end{tabular}


Table 2: Mineral profile of recovered protein powder recovered at 4,20 , and $40^{\circ} \mathrm{C}$.

\begin{tabular}{cccccc}
\hline Sample & $\begin{array}{c}\text { Fe } \\
\text { (mg/100g } \\
\text { sample) }\end{array}$ & $\begin{array}{c}\text { Mg } \\
\text { (mg/100g } \\
\text { sample) }\end{array}$ & $\begin{array}{c}\text { Ca } \\
\text { (mg/100g } \\
\text { sample) }\end{array}$ & $\begin{array}{c}\text { P } \\
\text { (mg/100g } \\
\text { sample) }\end{array}$ & $\begin{array}{c}\text { Na } \\
\text { (mg/100g } \\
\text { sample) }\end{array}$ \\
\hline IH & $2.35 \pm 0.21$ & $64.66 \pm 0.33$ & $1162.49 \pm 9.05$ & $954.59 \pm 6.56$ & $146.87 \pm 2.50$ \\
$\mathbf{4}^{\circ} \mathbf{C ~ P P}$ & $7.16 \pm 0.87$ & $188.06 \pm 1.05$ & $295.42 \pm 15.2$ & $2187.78 \pm 2.81$ & $818.27 \pm 3.66$ \\
$\mathbf{2 0}^{\circ} \mathbf{C ~ P P}$ & $6.33 \pm 0.01$ & $175.70 \pm 15.0$ & $288.84 \pm 5.87$ & $2107.44 \pm 55.2$ & $810.19 \pm 22.5$ \\
$\mathbf{4 0}^{\circ} \mathbf{C ~ P P}$ & $7.31 \pm 0.33$ & $190.86 \pm 3.79$ & $285.84 \pm 12.7$ & $2232.75 \pm 39.5$ & $806.74 \pm 49.3$ \\
\hline
\end{tabular}

$\mathrm{IH}$, Freeze-dried initial homogenate; PP, protein powder 
Table 3: Fatty acid composition of recovered protein powder recovered at 4,20 , and $40^{\circ} \mathrm{C}$ and freezedried initial homogenate.

\begin{tabular}{|c|c|c|c|c|}
\hline Fatty Acid & $\begin{array}{c}4^{\circ} \mathrm{C} \mathrm{PP} \\
(\%) \\
\end{array}$ & $\begin{array}{c}20^{\circ} \mathrm{C} \text { PP } \\
(\%) \\
\end{array}$ & $\begin{array}{c}40^{\circ} \mathrm{C} \text { PP } \\
(\%) \\
\end{array}$ & $\begin{array}{l}\text { IH } \\
(\%)\end{array}$ \\
\hline \multicolumn{5}{|l|}{$S F A s$} \\
\hline 14:0 & $4.06 \pm 0.30^{\mathrm{a}}$ & $3.08 \pm 0.09^{b}$ & $1.90 \pm 0.08^{\mathrm{c}}$ & $4.65 \pm 0.01$ \\
\hline 16:0 & $20.39 \pm 0.34^{\mathrm{a}}$ & $18.90 \pm 0.83^{b}$ & $17.33 \pm 0.12^{\mathrm{c}}$ & $17.12 \pm 0.03$ \\
\hline 18:0 & $7.79 \pm 0.46^{\mathrm{c}}$ & $8.92 \pm 0.51^{b}$ & $9.81 \pm 0.16^{\mathrm{a}}$ & $3.66 \pm 0.01$ \\
\hline \multicolumn{5}{|l|}{ MUFAs } \\
\hline 16:1 & $11.96 \pm 0.81^{\mathrm{a}}$ & $9.06 \pm 1.19^{b}$ & $6.62 \pm 0.05^{\mathrm{c}}$ & $14.20 \pm 0.01$ \\
\hline 18:1 & $17.09 \pm 0.64^{\mathrm{a}}$ & $14.63 \pm 1.11^{\mathrm{b}}$ & $12.17 \pm 0.25^{\mathrm{c}}$ & $17.82 \pm 0.03$ \\
\hline \multicolumn{5}{|l|}{ PUFAs } \\
\hline 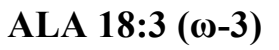 & $1.60 \pm 0.10$ & $1.57 \pm 0.10$ & $1.53 \pm 0.11$ & $4.13 \pm 0.01$ \\
\hline EPA 20:5 $(\omega-3)$ & $4.39 \pm 0.45^{\mathrm{c}}$ & $6.01 \pm 0.21^{\mathrm{b}}$ & $8.31 \pm 0.39^{\mathrm{a}}$ & $6.51 \pm 0.01$ \\
\hline 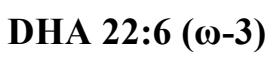 & $4.42 \pm 0.60^{\mathrm{c}}$ & $6.16 \pm 0.24^{\mathrm{b}}$ & $9.03 \pm 0.14^{\mathrm{a}}$ & $4.08 \pm 0.01$ \\
\hline $18: 2(\omega-6)$ & $1.47 \pm 0.06$ & $1.46 \pm 0.05$ & $1.42 \pm 0.03$ & $2.00 \pm 0.01$ \\
\hline $20: 4(\omega-6)$ & $2.30 \pm 0.33^{\mathrm{c}}$ & $3.23 \pm 0.06^{\mathrm{b}}$ & $4.62 \pm 0.06^{\mathrm{a}}$ & $1.10 \pm 0.00$ \\
\hline
\end{tabular}

SFAs, saturated fatty acids; MUFAs, monounsaturated fatty acids; PUFAs, polyunsaturated fatty acids; PP, protein powder; IH, Freeze-dried initial homogenate.

a, b, c Values with different letters in a row are significantly different as determined by Tukey's HD ( $p<$ $0.05)$ 
Table 4: Amino acid composition ( $\mathrm{mg} / \mathrm{g}$ protein) of recovered protein powder, initial silver carp homogenate, $80 \%$ whey protein, and the amino acid requirements for adults and infants.

\begin{tabular}{|c|c|c|c|c|c|c|c|}
\hline $\begin{array}{l}\text { Component } \\
\text { (mg/g protein) }\end{array}$ & $4^{\circ} \mathrm{C}$ PP & $20^{\circ} \mathrm{CPD}$ & $40^{\circ} \mathrm{C}$ DP & 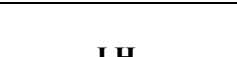 & WPC & 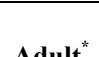 & Infant* \\
\hline \multicolumn{8}{|l|}{ EAAs } \\
\hline Arginine & $37.72 \pm 0.38$ & $37.84 \pm 0.46$ & $37.54 \pm 0.56$ & $65.46 \pm 0.14$ & 25 & - & - \\
\hline Histidine & $43.62 \pm 0.43$ & $44.23 \pm 0.32$ & $44.17 \pm 0.65$ & $28.34 \pm 0.43$ & 15 & 16 & 26 \\
\hline Isoleucine & $38.23 \pm 0.25$ & $38.59 \pm 0.57$ & $37.98 \pm 0.31$ & $46.10 \pm 0.71$ & 60 & 13 & 46 \\
\hline Leucine & $62.96 \pm 0.45$ & $63.16 \pm 0.58$ & $62.84 \pm 0.45$ & $74.94 \pm 1.28$ & 101 & 19 & 93 \\
\hline Lysine & $74.46 \pm 0.77$ & $74.82 \pm 0.86$ & $74.28 \pm 0.83$ & $89.17 \pm 2.00$ & 98 & 16 & 66 \\
\hline $\begin{array}{c}\text { Cysteine + } \\
\text { Methionine }\end{array}$ & $26.35 \pm 0.27$ & $26.57 \pm 0.30$ & $26.36 \pm 0.32$ & $37.22 \pm 0.43$ & 54 & 17 & 42 \\
\hline $\begin{array}{c}\text { Phenylalanine }+ \\
\text { Tyrosine }\end{array}$ & $64.74 \pm 0.65$ & $64.59 \pm 0.91$ & $64.89 \pm 1.35$ & $71.52 \pm 1.57$ & 59 & 19 & 72 \\
\hline Threonine & $32.13 \pm 0.36$ & $32.24 \pm 0.41$ & $32.16 \pm 0.35$ & $42.57 \pm 0.29$ & 67 & 9 & 43 \\
\hline Tryptophan & $11.49 \pm 0.27^{\mathrm{a}}$ & $11.41 \pm 0.27^{\mathrm{a}}$ & $11.01 \pm 0.22^{b}$ & $10.19 \pm 0.14$ & 15 & 5 & 17 \\
\hline Valine & $47.21 \pm 0.32^{\mathrm{ab}}$ & $47.72 \pm 0.65^{\mathrm{a}}$ & $46.93 \pm 0.48^{b}$ & $49.83 \pm 0.86$ & 55.7 & 13 & 55 \\
\hline Total EAA & 438.91 & 441.17 & 438.16 & 515.34 & 549.7 & 127 & 460 \\
\hline \multicolumn{8}{|l|}{ NEAAs } \\
\hline Alanine & $48.86 \pm 0.39$ & $48.93 \pm 0.35$ & $48.88 \pm 0.65$ & $64.05 \pm 0.14$ & 51 & & \\
\hline Aspartic Acid & $81.58 \pm 0.72$ & $81.95 \pm 0.81$ & $81.59 \pm 1.04$ & $94.41 \pm 1.14$ & 100 & & \\
\hline Cysteine & $9.88 \pm 0.06$ & $9.92 \pm 0.08$ & $9.85 \pm 0.10$ & $8.57 \pm 0.14$ & 34 & & \\
\hline Glutamic Acid & $83.74 \pm 0.84$ & $83.97 \pm 1.16$ & $82.98 \pm 1.09$ & $135.67 \pm 2.43$ & 166 & & \\
\hline Glycine & $51.07 \pm 0.47$ & $51.35 \pm 0.67$ & $51.39 \pm 0.97$ & $77.06 \pm 2.28$ & 17 & & \\
\hline Proline & $23.31 \pm 1.82$ & $24.15 \pm 0.59$ & $22.99 \pm 3.60$ & $48.41 \pm 1.14$ & 64 & & \\
\hline Serine & $28.17 \pm 0.49$ & $27.66 \pm 1.15$ & $27.92 \pm 0.51$ & $35.3 \pm 0.00$ & 51 & & \\
\hline Tyrosine & $23.21 \pm 0.32$ & $22.92 \pm 0.68$ & $23.01 \pm 0.92$ & $30.76 \pm 1.00$ & 28 & & \\
\hline Taurine & $25.98 \pm 0.45$ & $26.35 \pm 0.60$ & $26.55 \pm 0.53$ & $8.67 \pm 0.29$ & - & & \\
\hline Total NEAA & 375.8 & 377.2 & 375.16 & 502.9 & 511 & & \\
\hline
\end{tabular}

EAAs, Essential Amino Acids; NEAAs, Non-essential Amino Acids; PP, Recovered Protein Powder; IH, Freeze-dried initial homogenate; WPC $80,80 \%$ whey protein concentrate; AA, Amino acid.

${ }^{\mathrm{a}, \mathrm{b}}$ Values with different letters in a row are significantly different as determined by Tukey's $\operatorname{HD}(\mathrm{p}<0.05)$

*Adult and infant amino acid requirement were adapted from FAO/WHO/UNU (1985).

Note: WPC 80 data was adapted from Reference Manual for U.S. Whey and Lactose Products. Arlington VA: U.S. Dairy Export Council, 2005. P51-2. 
Figure 1: Linear regression plots of SFA (A), MUFA (B), and PUFA (C) concentrations in silver carp protein recovered at 4,20 , and $40^{\circ} \mathrm{C}$
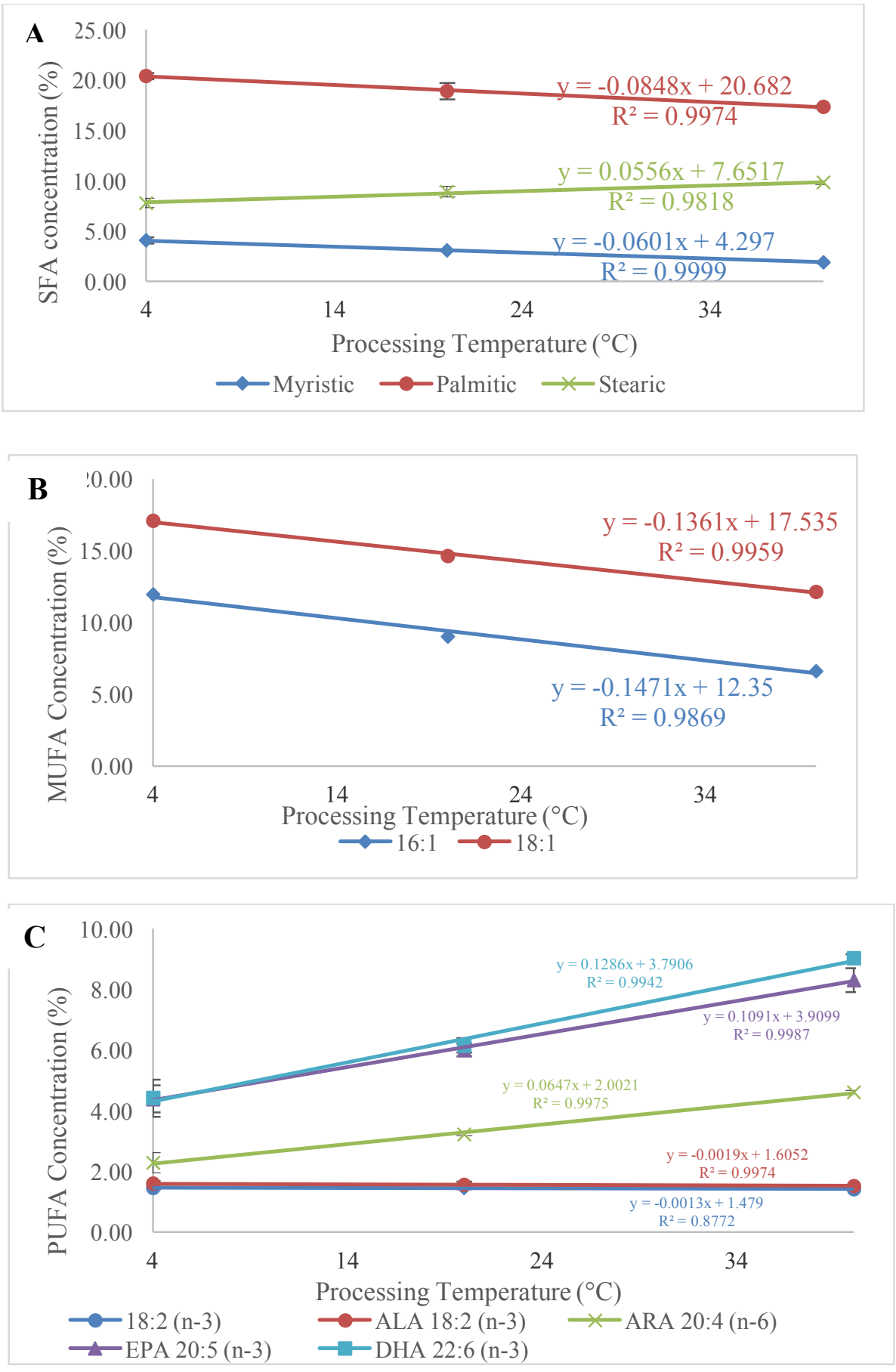
Figure 2: SDS-PAGE gel of the silver carp protein powder processed at $4^{\circ} \mathrm{C}$, whey protein concentrate and initial silver carp homogenate.
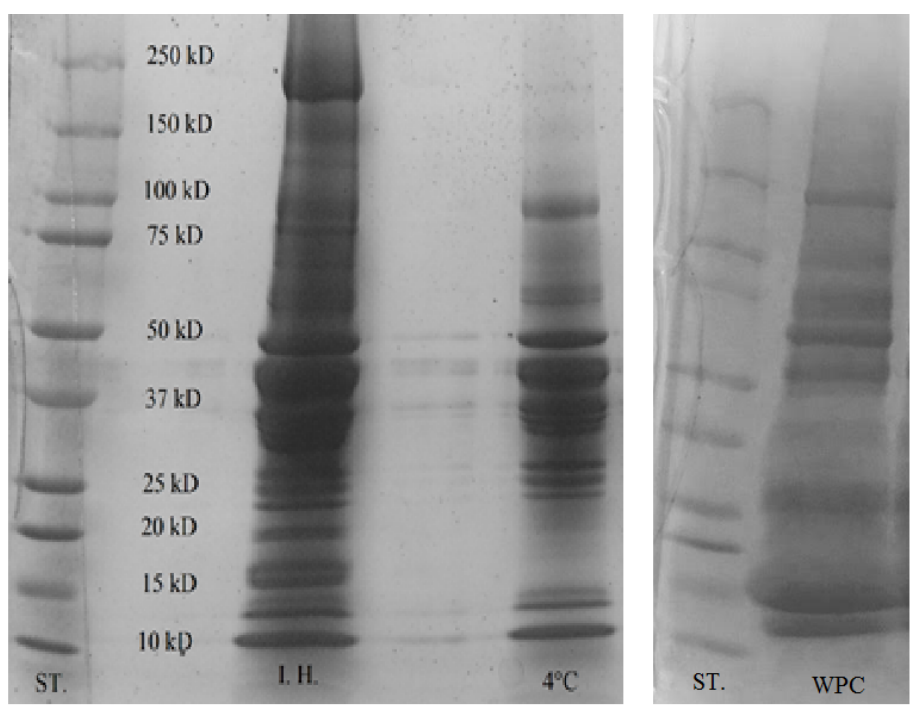

${ }^{\text {a }}$ ST., protein standard; I. H., initial homogenate; WPC, whey protein concentrate 
Figure 3: Representative 2-demensional electrophoresis gels of silver carp protein powders (A), Whey protein concentrate $(B)$ and initial silver carp homogenate $(C)$.
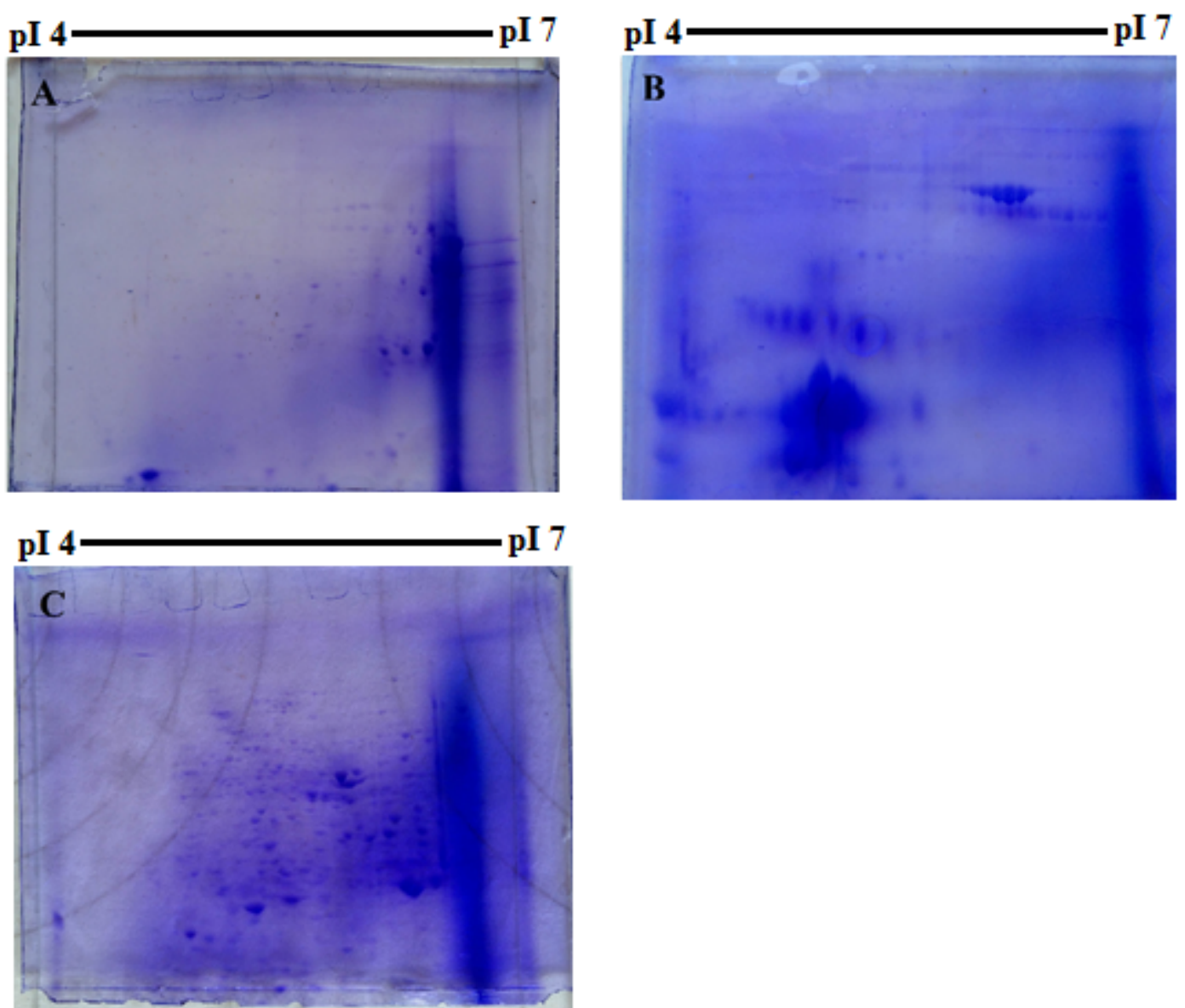
Figure 4: Solubility of recovered protein powder and WPC 80 in solutions of varying ionic strengths of $\mathrm{CaCl}_{2}, \mathrm{KCl}$, and $\mathrm{NaCl}$.

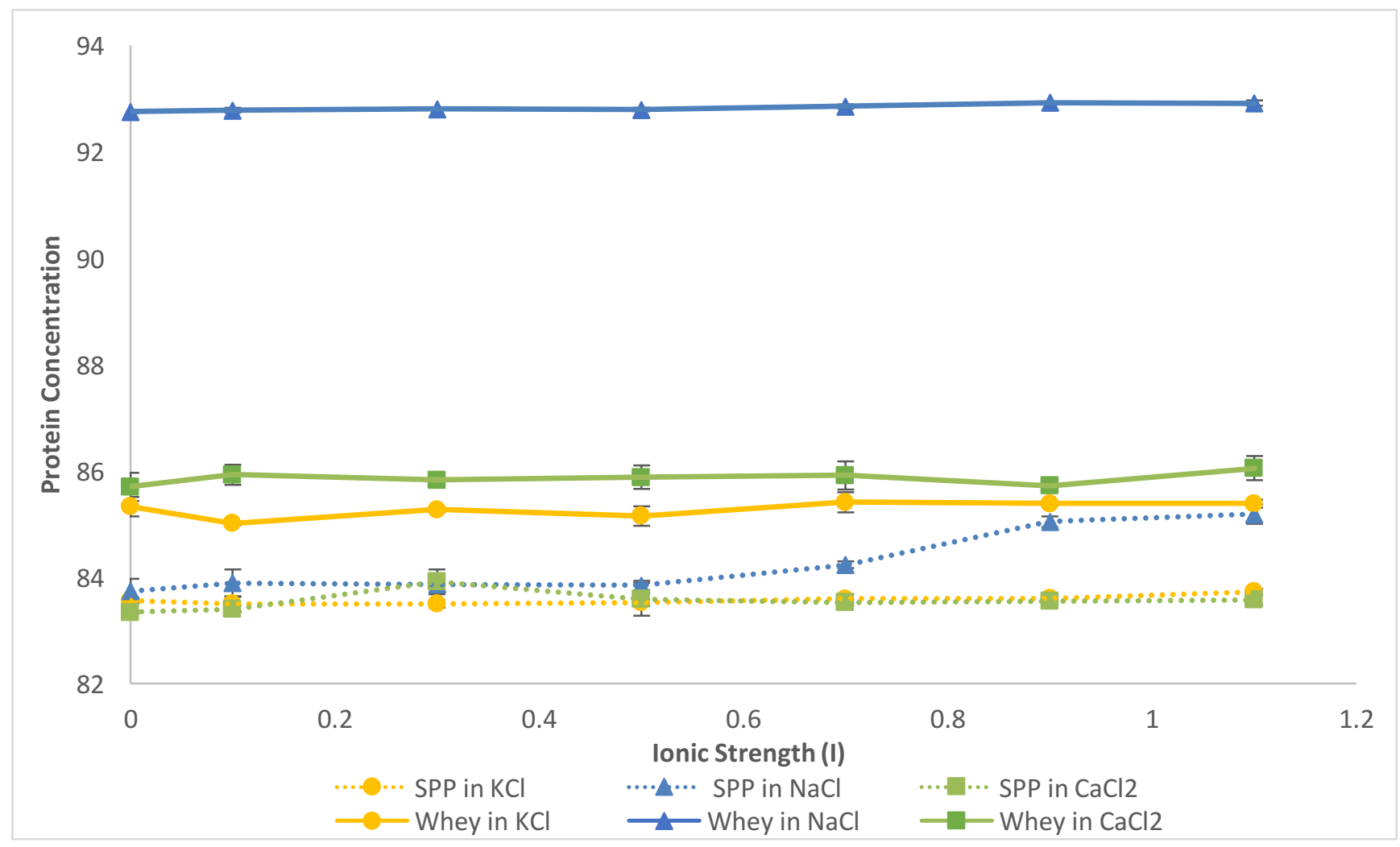

SPP, soluble protein powder 
Figure 5: Solubility of recovered protein powder and WPC 80 in solutions with varying $\mathrm{pH}$.

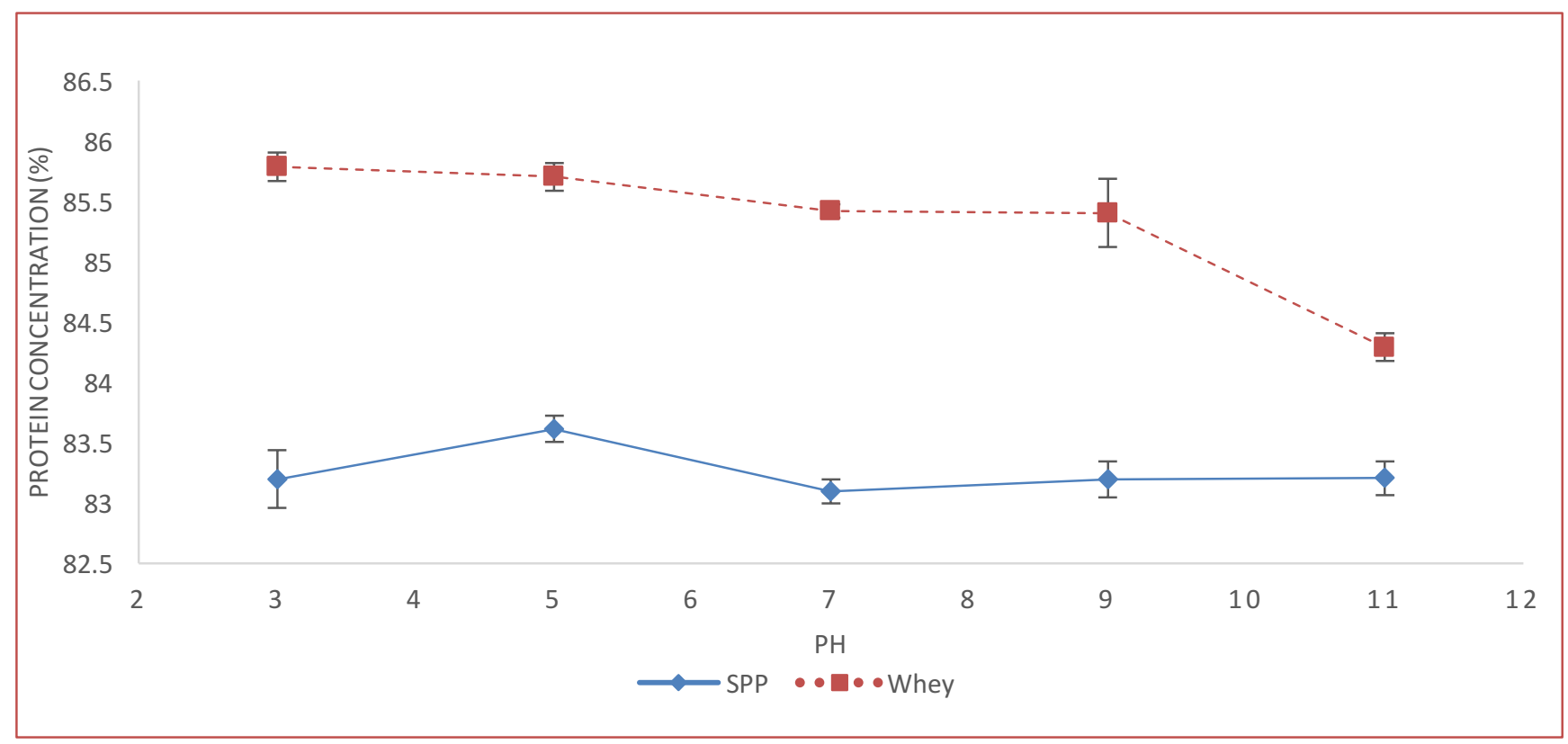

SPP, Soluble Protein Powder

\section{Chapter III}


Changes in soluble protein powders derived from silver carp (Hypophthalmichthys molitrix) and whey protein concentrate stored at ambient and elevated temperatures

Derek Warren, Jacek Jaczynski, Janet Tou, Kristen E. Matak*

West Virginia University, Animal and Nutritional Sciences, Morgantown, WV 26506, USA.

*Corresponding Author:

Dr. Kristen Matak

Phone: 304-293-2231

Email: kristen.matak@mail.wvu.edu

Choice of journal section where article should appear: 


\section{$\underline{\text { Abstract }}$}

Previous research has developed a method to extract water soluble proteins from silver carp for potential adaptation in the surimi industry. Once the soluble proteins are extracted in water, they can be dried into a protein rich protein powder (SPP) with similar nutritional properties to that of $80 \%$ whey protein concentrate (WPC). The aim of this research was to assess the shelf-stability of SPP and commercially sourced WPC at $20^{\circ} \mathrm{C}$ and $30^{\circ} \mathrm{C}$. Soluble proteins were extracted from silver carp, freeze-dried and powdered. The SPP and WPC were packaged in heat-sealed Mylar bags and stored at 20 and $30^{\circ} \mathrm{C}$ for nine months and samples were removed at $0,3,6$ and 9 months for analysis. Changes in color, TBARS, $\mathrm{pH}$, water activity, microbial plate counts, and amino acid profile was measured. Storage of the SPP at $30^{\circ} \mathrm{C}$ resulted in the greatest change in shelf-stability measures. SPP stored at $30^{\circ} \mathrm{C}$ exhibited significantly greater reductions in $\mathrm{pH}(-0.34)$, whiteness $(-15.31)$, and lysine content ($10.50 \mathrm{mg} / \mathrm{g}$ protein $)$. Higher rates $(\mathrm{p}<0.05)$ of lipid oxidation were observed in SPP samples when compared to WPC. Water activity for all samples increased over time due to the release of bound water. Microbial plate count revealed an initial countable population of mesophillic bacteria in the SPP sample of $3.53 \log \mathrm{CFU} / \mathrm{g}$. All other plates, including coliform and fungal plates came back at undetectable levels (30 - 300 CFU). Results from this study indicate SPP is not as shelf stable as WPC according to measures tested. The purchased WPC contained lactose and soy lecithin not present in SPP. The addition of these ingredients may have enhanced the shelf-stability of WPC. 


\section{$\underline{\text { Introduction }}$}

The recommended shelf-life for whey protein concentrate (WPC) at room temperature is $9-12$ months, which can be extended to 24 months if stored at $4^{\circ} \mathrm{C}$ (Tunick et al., 2015). During dry storage, it is common to see changes in shelf-stability measures such as whiteness, amino acid content, lipid oxidation, $\mathrm{pH}$, and water activity, among others. Whey protein commonly undergoes the Maillard reaction and lipid oxidation (Tunick et al., 2015). Whey protein concentrate (80\%) is thought to contain roughly $80 \%$ protein and $20 \%$ lactose. Lactose, a reducing sugar, contained in such an amount could elevate the rate of the Maillard reaction. The Maillard reaction involves the carbonyl groups of reducing sugars or aldehydes reacting with amino acids resulting in the yellowing or browning of the product (Artharn et al., 2009). Lysine readily reacts with reducing sugars, resulting in reductions in lysine content (Tunick et al., 2015). Lipid oxidation occurs as a function of lipid content and presence of oxygen; thus whey protein is typically vacuum packaged (Artharn et al., 2009; Stine et al., 2012). Additionally, degradation of lipids into free fatty acids results in a reduction of $\mathrm{pH}$ (Tunick et al., 2015). During storage, it is also expected for protein powders to exhibit an increase in water activity overtime. This is due to the lyses of proteins into smaller peptides producing water, increasing free water in the product (Tunick et al., 2015). Water activity and $\mathrm{pH}$ are factors that readily affect microbial growth. The water activity required for the majority of halophilic bacteria is 0.75 . Increases of water activity during storage above 0.75 would provide an environment favorable for microbial proliferation and increase the risk of foodborne illness (Jay et al., 2005). Continued commercial success of whey protein concentrates are dependent on maintaining quality standards for the duration of the expected shelf-life. 
Historically whey was seen as a by-product of the dairy industry, but this view changed when government regulations on whey disposal were implemented. These governmental regulations forced the dairy industry to conduct research on whey disposal that resulted in it being repurposed as a source of high quality protein (Smithers, 2008). Similar to whey, water used in the fish processing industry contains valuable water soluble proteins and other nutrients that tend to be discarded homologous to how whey protein was once discarded during dairy processing. It is possible to separate and repurpose these proteins as a source of high quality protein. Therefore, soluble proteins were recovered from silver carp using a hydro-centrifugation method (Warren et al., 2017). Recovered protein was freezedried and powdered. The proximate composition of the recovered protein powder was approximately $82 \%$ protein, $3 \%$ lipid and $14 \%$ ash, met all of the essential amino acid requirements for adults, and was highly soluble in low saline solutions (Warren et al., 2017). The aim of this current study was to assess the shelf stability of a soluble protein powder derived from ground silver carp stored under both ambient $\left(20^{\circ} \mathrm{C}\right)$ and abused $\left(30^{\circ} \mathrm{C}\right)$ conditions then compare to that of WPC containing $80 \%$ protein. 


\section{Methods}

\section{Fish Preparation:}

Headed and gutted silver carp were purchased from FIN Inc (Kentucky, USA) and shipped on ice through overnight mail to the West Virginia University Agricultural Sciences Building. All fins and tails were removed with a band saw (Hobart, Model \# 27-1174-894) and the fish were cut into steaks. Steaks were allowed to rest overnight at $4^{\circ} \mathrm{C}$ then were twice course ground into a fish paste using a meat grinder (Hobart, Model \# $4146 \mathrm{SS}$ ). The paste was spread $7 \mathrm{~cm}$ thick and stored at $-20^{\circ} \mathrm{C}$ for 1 hour or until a frozen crust was present. The paste was finely ground in the meat grinder and divided into $500 \mathrm{~g}$ vacuum sealed bags. Sealed bags of ground fish homogenate were stored at $-20^{\circ} \mathrm{C}$ overnight then moved to storage at $-80^{\circ} \mathrm{C}$ until utilization.

\section{Sarcoplasmic Protein Powder Production:}

Stored bags of ground fish homogenate thawed for 48 hours at $4^{\circ} \mathrm{C}$. Once thawed, $500 \mathrm{~g}$ of ground fish homogenate was added to $1500 \mathrm{~mL}$ of deionized and distilled water. The mixture was homogenized (Omni International, Model GLH-01) for 10 minutes at speed setting 3. The resulting slurry was centrifuged at $10,000 \mathrm{G}$ for $15 \mathrm{~min}$ at $4{ }^{\circ} \mathrm{C}$. The liquid sarcoplasmic process water was decanted through cheese cloth then heated to $40^{\circ} \mathrm{C}$ on a hot plate. The heated sarcoplasmic protein

process water was centrifuged at $10,000 \mathrm{G}$ for $15 \mathrm{~min}$ at $40^{\circ} \mathrm{C}$. A $500 \mathrm{~mL}$ syringe was used to extract the liquid sarcoplasmic process water without disruption of the floating lipid layer. The sarcoplasmic protein process water was transferred to $4 \mathrm{~L}$ freeze-drying trays and stored at $-20^{\circ} \mathrm{C}$ until freeze drying. Freeze drying (VirTis, Model \#35L) was completed in approximately 15 days or when the chamber reach $21^{\circ} \mathrm{C}$.

\section{Sample Bags and Environments:}


Sarcoplasmic protein powder (20 g) was packaged into $8 \times 8$ inch Mylar vacuum bags (DryPack, MB8×8) within 15 minutes of being removed from the freeze-dryer. Mylar bags full of sarcoplasmic protein were compressed to remove excess air then heat sealed. Whey protein concentrate $(80 \%)$, purchased from a food wholesaler (bulkfoods.com), was stored at $-20^{\circ} \mathrm{C}$ until packaging in the same manner. Sealed bags were placed in closed cardboard boxes and stored on a laboratory self under ambient conditions or in an incubator (Fisher Scientific, Model\# 537D) set to $30^{\circ} \mathrm{C}$. Bags of sarcoplasmic protein powder and whey protein concentrate were removed at $0,3,6$, and 9 month time intervals and stored at $-80^{\circ} \mathrm{C}$ until analysis occurred.

\section{Proximate Composition:}

Proximate composition analysis (moisture, ash, crude protein and lipid) was verified on the initial fish paste, the powdered soluble protein powder and whey protein concentrate.

The oven drying method was used to determine the moisture content of the samples. Samples measuring $2 \mathrm{~g}$ were placed in a $105^{\circ} \mathrm{C}$ oven overnight. The following formula was used to determine the moisture content (ASTM, 1993);

Moisture content $(\mathrm{MC})=\frac{\text { Initial weight-Oven dried weight }}{\text { Initial weight }} \times 100$ of total mass

Samples that had been oven dried for the moisture content assay were placed into a muffle furnace for $24 \mathrm{~h}$ at $550{ }^{\circ} \mathrm{C}$ (Otto et al.). The ash content was calculated using the following formula (ASTM, 1993);

Ash content $(\mathrm{AC})=\frac{\text { Dried weight }}{\text { Initial weight }} \times 100$ of total mass

The Kjeldahl assay was used to determine crude protein content. There were three steps to this assay: sample digestion, distillation, and titration. The number of moles of base was subtracted from 
the number of moles of acid used in the titration to give the moles of nitrogen. Once the number of moles of nitrogen in the sample was determined, it was multiplied by 14.0067 (Nitrogen's atomic mass) to convert it into grams of nitrogen. Grams of protein was calculated by multiplying the number of grams of nitrogen by 6.25 .

The Soxhelt extraction method was used to measure the lipid content of the samples. A 1 gram aliquot of each sample was placed into a petroleum ether extraction for $15 \mathrm{~h}$ with a drip rate of 10 $\mathrm{mL} / \mathrm{min}$ (Otto et al.).

\section{Color Analysis:}

A colorimeter (Minolta Camera Co. Ltd, Osaka, Japan) was used to measure color changes of the sarcoplasmic protein powder and $80 \%$ whey protein concentrate. The colorimeter was calibrated using a standard white plate No.21333180 (CIE L* 93.1; $a^{*} 0.3135 ; b^{*} 0.3198$ ). Values of L* (lightness; scale: 0 - 100), a* (red color intensity; scale: $-60-+60$ ), and b* (yellow color intensity; scale: $-60-+60)$ were recorded in triplicate and the following equation was used to calculate whiteness:

Whiteness $=100-\left[(100-\mathrm{L})^{2}+\mathrm{a}^{2}+\mathrm{b}^{2}\right]^{1 / 2}$

Color was measured in triplicate for each stored sample.

pH:

The $\mathrm{pH}$ of the sarcoplasmic protein powder and whey protein concentrate were measure in triplicate by mixing $7 \mathrm{ml}$ of deionized and distilled water with $3 \mathrm{~g}$ of the protein powders. The solution was stirred for one hour at room temperature before $\mathrm{pH}$ was recorded.

\section{Water Activity:}


Water activity $\left(\mathrm{a}_{\mathrm{w}}\right)$ was measured on sarcoplasmic protein powder and whey protein concentrate. Water activity was recorded in triplicate by AquaLab 4TE water activity meter (Decagon Devices, Pullman, WA). Samples cups were filled with enough protein powder to cover the bottom, prior to being places in the calibrated water activity meter. Water activity was recorded in triplicate for each sample and the average was determined.

\section{Microbiology:}

Microbial population of SPP and WPC concentrate was enumerated. Methods adapted from Ukuku et al. (2014) were used to plate bacteria, yeast, mold, and coliform populations on agar. Briefly, $1 \mathrm{~g}$ of protein powders were mixed with $9 \mathrm{~mL} 0.10 \%$ buffered peptone water and vortexed for $30 \mathrm{~s}$. Following vortexing, $100 \mathrm{uL}$ of diluted powder was spread on agar plates. Tryptic soy agar (Acumedia, Neogen, Lancing, MI) was used to plate mesophilic aerobic bacteria and incubated for 24 hours at $36^{\circ} \mathrm{C}$. Dichoran Rose Bengal Chloramphenicol agar (Acumedia, Neogen, Lancing, MI) was used to plate spoilage yeast and molds and incubated for 5 days at $23^{\circ} \mathrm{C}$. Violet red bile agar (Acumedia, Neogen, Lancing, MI) was used to plate coliforms and incubated for 24 hours at $36^{\circ} \mathrm{C}$. Three replicates of each sample was completed and averages were calculated. Methods described by Hitchins et al. (1992) microbial enumeration.

\section{Amino Acid Analysis:}

Amino acid analysis was complete by the University of Missouri-Columbia. All analyses were conducted in accordance to the Association of Official Analytical Chemists methods (AOAC, 1995; AOAC $982.30 \mathrm{E})$. Acid hydrolysis was completed using hydrochloric acid $(6 \mathrm{~N})$ for $24 \mathrm{~h}$ at $110^{\circ} \mathrm{C}$. Oxidation of hydrolyzed samples was performed with performic acid at $0-5^{\circ} \mathrm{C}$ overnight. Acid hydrolysis with $\mathrm{HCl}$ was repeated then followed by alkaline hydrolysis for $22 \mathrm{~h}$ with $4.2 \mathrm{~N} \mathrm{NaOH}$ at $110^{\circ} \mathrm{C}$. A Beckman Amino Acid Analyzer (model 6300, Beckman Coulter, Inc., Fullerton CA) was 
used to quantify amino acid profiles, following hydrolysis. Step gradients of sodium citrate buffers with the cation exchange postcolumn ninhydrin derivation were utilized.

\section{TBARS:}

Lipid oxidation-triobabituric acid reactive substances (TBARS) was completed according to methods described by Yu and Sinnhuber (1957). Briefly, samples $(0.200 \mathrm{~g})$ were weighed in $35 \mathrm{~mL}$ screw capped centrifuge tube. Antioxidant mixture (3 drops) and $17 \mathrm{~mL}$ of TCA-HCl reagent were added to the tubes. The tubes were flushed with nitrogen gas then vortexed. Subsequently, $3 \mathrm{~mL}$ of TBA solution was added. The tube was flushed with nitrogen gas, vortexed, then allowed to incubate for $35 \mathrm{~min}$ at $95^{\circ} \mathrm{C}$. Once incubation completed, the samples were placed on ice and $5 \mathrm{~mL}$ of chloroform was added. The tubes were vortexed and centrifuged at $1000 \mathrm{G}$ for $10 \mathrm{~min}$ at $4^{\circ} \mathrm{C}$. The resulting top layer was transferred to a cuvette and the absorbance at $535 \mathrm{~nm}$ was recorded.

Concentration of MDA was calculated using the following equation:

MDA concentration $\left(\frac{\mathrm{mg}}{\mathrm{kg} \mathrm{sample}}\right)=\frac{\text { Abs. } \times \text { MW of MDA } \times 1000 \mathrm{mg} \times \text { Sample volume } \times 1000 \mathrm{~g}}{\text { molar absorbance } \times 1000 \mathrm{~mL} \times \mathrm{kg} \text { of sample }}$.

\section{Statistical Analysis:}

Biological replicates were conducted consecutively with the soluble protein powder and WPC 80 at $0,3,6$, and 9 month time intervals. All analyses were completed in triplicate. SAS JMP Pro version 11 (JMP 1998-2012) was used for all statistical measures. One-way analysis of variance and Tukey-Kramer's honestly significant differences tests were used to identify significant differences $(\alpha=0.05)$.

\section{$\underline{\text { Results and Discussion }}$}

Water Activity 
Figure 1 shows the changes in water activity with respect to time for the WPC and SPP stored at ambient $\left(20^{\circ} \mathrm{C}\right)$ and elevated $\left(30^{\circ} \mathrm{C}\right)$ temperatures. Water activity for SPP stored at both 20 and $30^{\circ} \mathrm{C}$ increased with respect to time. The difference in water activity was significantly greater $(\mathrm{p}<0.05)$ for the samples stored at $30^{\circ} \mathrm{C}$, increasing from $0.16 \pm 0.03$ to $0.43 \pm 0.004$ at 9 months. Water activity of SPP samples stored at $20^{\circ} \mathrm{C}$ increased by approximately 0.11 to $0.27 \pm 0.004$ at 9 months. Water activity of WPC increased with time for samples stored at $30^{\circ} \mathrm{C}$. Samples stored at $30^{\circ} \mathrm{C}$ significantly increased $(p<0.05)$ by approximately 0.04 . There was not a significant difference between month 0 and month 9 samples of WPC stored at $20^{\circ} \mathrm{C}$. No difference $(\mathrm{p}>0.05)$ was identified between the WPC samples stored at 20 and $30^{\circ} \mathrm{C}$ until 9 months of storage. At 9 months, WPC stored at $30^{\circ} \mathrm{C}$ had a significant greater water activity at $0.29 \pm 0.01$. Similar increases, from 0.28 to 0.31 , in water activity were seen with 80\% WPC stored for 18 months (Tunick et al., 2015).

It is expected that the water activity of powders, composed of mostly protein, will exhibit an increase in water activity during storage. Proteins break down during dry storage, releasing bound water causing a rise in available water (water activity) in the product (Tunick et al., 2015). Interestingly SPP stored at $30^{\circ} \mathrm{C}$ exhibited the greatest increase in water activity while SPP stored at $20^{\circ} \mathrm{C}$ exhibited the smallest. This indicates storage at $20^{\circ} \mathrm{C}$ reduces the amount of protein break down, reducing water release. Additionally, WPC 80 contains approximately $20 \%$ lactose. The Maillard reaction between amino acids and reducing sugars also results in the production of water, increasing the amount of available water. Therefore, it could be expected for the water activity of WPC to increase over time. However, it is likely that the water activity of the WPC remained constant over the storage period due to the hygroscopic nature of lactose. The purchased WPC contained soy lecithin. 
The amphiphilic nature of lecithin in addition to the breakdown of peptides may have prevented changes in water activity in the WPC sample.

Although water activity was the greatest at month 9 for SPP stored at $30^{\circ} \mathrm{C}$. The maximum value was lower than the water activity required for the majority of spoilage bacterial and fungal growth of 0.91 and 0.80 , respectively. Additionally, the water activity of the stored SPP is lower than the water activity required for halophilic bacteria of 0.75 , indicating microbial growth should not be an issue (Jay at al., 2005). Population of mesophilic aerobic bacteria, spoilage yeast and molds, and coliforms were confirmed using the appropriate agars and reported. Coliforms and spoilage yeast and molds were not detected in stored WPC or SPP samples with the detectable level of 30 - 300 CFU/plate. Mesophilic bacteria were detected only in the initial SPP at $4.28 \pm 0.04 \log$ CFU/g and did not persist overtime. The total viable plate count on fresh fish fillets revealed an initial count of 3.53 $\log \mathrm{CFU} / \mathrm{g}$, which is well below the maximum acceptable level of $7.0 \log \mathrm{CFU} / \mathrm{g}$ for fresh fish (Kachele et al., 2017; Wang et al., 2014). The microbial load of fish is dependent on multiple factors: species, agricultural practices, manufacturing practices, water temperature, and transportation conditions.

\section{Colorimetry}

The whiteness of SPP and WPC samples are reported in Figure 2. Storage of WPC for 9 months at $20^{\circ} \mathrm{C}$ resulted in no significant changes $(\mathrm{p}>0.05)$ in whiteness. WPC stored at $30^{\circ} \mathrm{C}$ resulted in a significant decrease $(p<0.05)$ in whiteness value when compared to the initial WPC sample. No difference $(\mathrm{p}<0.05)$ was identified in whiteness as a result of storage temperature. Tunick et al. (2015) reported significant increases in sample yellowing when stored at $30^{\circ} \mathrm{C}$. Whiteness of SPP stored at 20 and $30^{\circ} \mathrm{C}$ significantly decreased $(\mathrm{p}<0.05)$ with storage time. Initial SPP whiteness of 
$67.88 \pm 0.92$ dropped to $52.57 \pm 1.05$ when stored for 9 months at $30^{\circ} \mathrm{C}$. Storage for 9 months at $20^{\circ} \mathrm{C}$ resulted in a decrease in whiteness to $63.22 \pm 1.02$. SPP stored at $30^{\circ} \mathrm{C}$ resulted in a significantly lower $(\mathrm{p}<0.05)$ whiteness value at 9 months when compared to SPP stored at $20^{\circ} \mathrm{C}$. A decrease in whiteness is associated with yellowing or darkening of the sample. Yellowing, an indication of Maillard browning, occurs due to carbonyl groups of reducing sugars (i.e. lactose) reacting with amino groups of proteins resulting in a yellowing/browning effect and bitter taste (Jay et al., 2005). The Maillard reaction would result in in the yellowing of WPC over time; however, Maillard reaction was reported to induce color changes in mackerel powders and silver carp fillets with storage time (Artharn et al., 2009; Kachele et al., 2017). In addition, the presence of hemoglobin in the SPP sample was likely responsible for the darker initial color and oxidation of the hemoglobin likely contributed to the further darkening affect over the storage time.

$p H$

The $\mathrm{pH}$ of SPP and WPC stored for 9 months at 20 and $30^{\circ} \mathrm{C}$ was recorded (Figure 3). The initial $\mathrm{pH}$ of SPP and WPC was $\mathrm{pH} 6.62 \pm 0.03$ and $\mathrm{pH} 6.55 \pm 0.01$, respectively. While the $\mathrm{pH}$ of SPP stored at $30^{\circ} \mathrm{C}$ decreased significantly $(\mathrm{p}<0.05)$ over the storage period, there were only minor reductions in $\mathrm{pH}$ of the WPC. The greatest reduction in $\mathrm{pH}$ occurred in SPP when stored at $30^{\circ} \mathrm{C}$ indicates storage at higher temperatures accelerate lipid break down. Degradation of lipids into free fatty acids result in the reduction of $\mathrm{pH}$ (Tunick et al., 2015). Verification of proximate composition revealed the lipid content of SPP $(3.98 \pm 0.66 \%)$ was four times greater than WPC $(0.83 \pm 0.11 \%)$. A greater depression in $\mathrm{pH}$ would be expected in SPP samples due to greater lipid content.

\section{TBARS}


Lipid oxidation of SPP and WPC samples stored at 20 and $30^{\circ} \mathrm{C}$ were determined by measuring TBARS (Figure 4). Lipid oxidation was significantly greater $(p<0.05)$ in SPP samples compared to WPC samples at every time point, likely due to the greater lipid content. Storage temperature had no significant impact $(\mathrm{p}>0.05)$ on lipid oxidation; however, MDA in WPC stored at $30^{\circ} \mathrm{C}$ significantly increased $(\mathrm{p}<0.05)$ to $3.04 \pm 0.28 \mathrm{mg} \mathrm{MDA} / \mathrm{kg}$ sample at 3 months of storage. Following 3 months, lipid oxidation values declined to (2.59 $\pm 0.09 \mathrm{mg} \mathrm{MDA} / \mathrm{kg}$ sample). Research by Stine et al., (2012) reported increases in lipid oxidation with storage time. Artharn and others (2009) utilized a film to cover mackerel powder, limiting contact with oxygen, leading to lower levels of lipid oxidation. Both SPP and WPC were stored in sealed Mylar bags with the air removed by pressing, limiting the contact the powders had with oxygen. Without exposure to light or oxygen, it was expected for lipid oxidation value to remain constant.

\section{Amino Acid Profile}

An amino acid profile was conducted on WPC samples stored for 9 months at 20 and $30^{\circ} \mathrm{C}$. Changes in individual amino acid concentration were calculated (Tables $2 \&$ 3). Limited changes in amino acid profile of stored WPC was seen. When stored at $20^{\circ} \mathrm{C}$, arginine, lysine, and glutamic acid were the only amino acids to exhibit significant reductions $(\mathrm{p}<0.05)$. With lysine showing the greatest reduction of $-2.58 \pm 0.30 \mathrm{mg} / \mathrm{g}$ protein at 9 months of storage. No significant differences in amino acid content was observed when WPC was stored at $30^{\circ} \mathrm{C}$. However, a greater reduction $(\mathrm{p}<$ $0.05)$ of lysine content $\left(-5.15 \pm 0.79 \mathrm{mg} / \mathrm{g}\right.$ protein) was observed when samples were stored at $30^{\circ} \mathrm{C}$ for 9 months. Greater lysine loss and browning were observed in samples stored at $30^{\circ} \mathrm{C}$. Indicating, the Maillard reaction, the reaction between reducing sugars and amino acids, may have caused the reduction. Lysine is known to react readily with reduction sugars. WPC is rich in lysine with lysine 
being the second most abundant essential amino acid behind the branch chain amino acid, leucine in samples. Branch chain amino acids enhance the building of muscle by inhibiting protein degradation while promoting protein synthesis (Tunick et al., 2015; Monirujjaman and Ferdouse, 2014).High branch chain amino acid content of whey protein is a cause for its utilization in protein supplements. The results indicate the amino acid profile of WPC is stable for up to 9 months with minor significant differences $(\mathrm{p}<0.05)$ resulting when stored at 20 and $30^{\circ} \mathrm{C}$,

The changes in the amino acid profile of SPP stored at 20 or $30^{\circ} \mathrm{C}$ for 9 months were analyzed in Tables 4 and 5. Limited changes were seen in samples stored at $20^{\circ} \mathrm{C}$ with proline being the only amino acid to exhibit and significant $(\mathrm{p}<0.05)$ reduction during 9 months of storage. Storage at $30^{\circ} \mathrm{C}$ resulted in significant declines $(\mathrm{p}<0.05)$ in composition of the majority of essential amino acid, with histidine and lysine exhibiting the greatest reduction at $-11.27 \pm 0.09$ and $-10.50 \pm 0.36$ respectively. A reduction was observed from 0 to 6 months. Amino acid content at 9 months, unexpectedly increased to levels similar to that of month 3. A similar pattern was seen in whiteness of SPP stored at $30^{\circ} \mathrm{C}$. Indicating the Maillard reaction may be responsible for the breakdown of amino acids, with the rate of reaction increasing with temperature and time. It was expected for the amino acid content to decrease throughout the study. However, an increase in 3 amino acids (aspartic acid, alanine, and proline) was identified in honey stored for 6 months (Iglesias et al., 2006). With enzyme activity being accredited for the increase in amino acid content. When compared to the amino acid profiles of the stored WPC, the amino acids found in the soluble protein powder were shown to be less stable at ambient temperatures and $30^{\circ} \mathrm{C}$. This could be accredited to the addition of lecithin to the WPC. Lecithin, an amphiphillic emulsifier, may have stabilized amino acids in the WPC, preventing greater reductions in amino acid content. 


\section{Conclusion}

The goal of this research was to analyze the shelf stability of a soluble protein powder produced from silver carp stored at 20 or $30^{\circ} \mathrm{C}$ and compared to that of whey protein concentrate. The results from this study suggest warmer storage temperatures result in greater degeneration of both SPP and WPC, with $30^{\circ} \mathrm{C}$ storage resulting in the greatest increase in water activity, amino acid degradation, and $\mathrm{pH}$ reduction and whiteness values. In order to combat these issues, preservatives could be added to SPP to maintain shelf stability. It would be interesting to investigate shelf life indicators of the soluble protein powder and WPC containing the same additives (antioxidants, emulsifiers, etc.) in the same concentrations. Future research should also analyze consumer safety and acceptance. 


\section{$\underline{\text { References }}$}

1. Artharn, A., Prodpran, T., \& Benjakul, S. (2009). Round scad protein-based film: Storage stability and its effectiveness for shelf-life extension of dried fish powder. Food Science and Technology, 42, 1238-1244.

2. Arvanitoyannis, I. S. and Kassaveti, A. (2008), Fish industry waste: treatments, environmental impacts, current and potential uses. International Journal of Food Science \& Technology, 43: 726-745

3. Fisheries and Aquaculture topics. Proteins from fish and fish products. Topics Fact Sheets. Text by Lahsen Ababouch. In: FAO Fisheries and Aquaculture Department [online]. Rome. Updated 27 May 2005.

4. Fisheries and Aquaculture topics. Waste management of fish and fish products. Topics Fact Sheets. Text by Lahsen Ababouch. In: FAO Fisheries and Aquaculture Department [online]. Rome. Updated 27 May 2005.

5. FAO-WHO (2011). Report of the Joint FAO-WHO Expert Consultation on the Risks and Benefits Associated with Fish Consumption. FAO Fisheries and Aquaculture Technical Paper 978.

6. Food and Agriculture Organization of the United Nations (FAO), The State of World Fisheries and Aquaculture, 2014. Rome.

7. Iglesias, M. T., Martín-Álvarez, P. J., Polo, M. C., Lorenzo, C. D., González, M., \& Pueyo, E. (2006). Changes in the Free Amino Acid Contents of Honeys During Storage at Ambient Temperature. Journal of Agricultural and Food Chemistry, 54(24), 9099-9104. 
8. Islam, M., Khan, S., \& Tanaka, M. (2004). Waste loading in shrimp and fish processing effluents: Potential source of hazards to the coastal and nearshore environments. Marine Pollution Bulletin, 49, 103-110.

9. Jay, J. M. (2005). Modern food microbiology. New York: Springer.

10. Kachele, R., Zhang, M., Gao, Z., \& Adhikari, B. (2017). Effect of vacuum packaging on the shelf-life of silver carp (Hypophthalmichthys molitrix) fillets stored at $4{ }^{\circ} \mathrm{C}$. LWT - Food Science and Technology, 80, 163-168.

11. Knap, Renata. "Trends and Factors of Development of the World Consumption of Fish and Fishery Products." Folia Oeconomica Stetinensia 10.1 (2011): 213. ProQuest. Web. 24 Aug. 2015.

12. Listiohadi, Y., Hourigan, J., Sleigh, R., \& Steele, R. (2008). Moisture sorption, compressibility and caking of lactose polymorphs. International Journal of Pharmaceutics, 359(1-2), 123-134. doi:10.1016/j.ijpharm.2008.03.044

13. Monirujjaman, M., \& Ferdouse, A. (2014). Metabolic and Physiological Roles of BranchedChain Amino Acids. Advances in Molecular Biology, 2014, 1-6. doi:10.1155/2014/364976

14. Ruxton, C. (2011). The benefits of fish consumption. Nutrition Bulletin, 36, 6-19.

15. Stine, J., Pedersen, L., Smiley, S., \& Bechtel, P. (2012). Recovery And Utilization Of Protein Derived From Surimi Wash-Water. Journal of Food Quality, 35(1), 43-50.

16. Tunick, M. H., Thomas-Gahring, A., Van Hekken, D. L., Iandola, S. K., Singh, M., Qi, P. X., Ukuku, D. O., Mukhopadhyay, S., Onwulata, C. I., and Tomasula, P. M. (2016). Physical and chemical changes in whey protein concentrate stored at elevated temperature and humidity. Journal of Dairy Science, 99(3), 2372-2383. 
17. Wang, H., Luo, Y., Huang, H., \& Xu, Q. (2014). Microbial succession of grass carp (Ctenopharyngodon idellus) filets during storage at $4^{\circ} \mathrm{C}$ and its contribution to biogenic amines' formation. International Journal of Food Microbiology, 190, 66-71.

18. Warren, D., Jacynski, J., Tou, J., and Matak, K. (2017). Characterization of soluble proteins recovered from silver carp: Impact of protein recovery processing temperature on nutritional quality and physical characteristics of silver carp soluble protein powders. Unpublished manuscript.

19. Weichselbaum, E., Coe, S., Buttriss, J., \& Stanner, S. (2013). Fish in the diet: A review. Nutrition Bulletin, 38(2), 128-177. 


\section{Figures and Tables}

Figure 1: Water activity of SPP and WPC stored at 20 and $30^{\circ} \mathrm{C}$ for 9 months

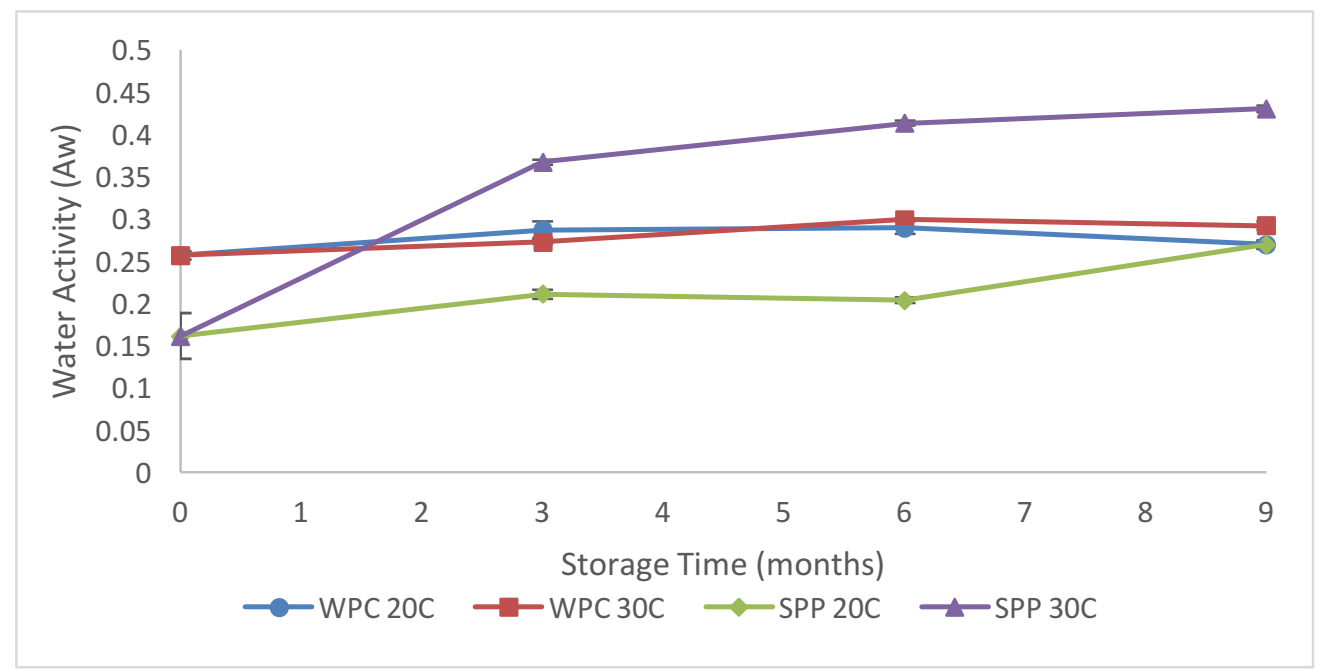

WPC $20 \mathrm{C}$, whey protein concentrate stored at $20^{\circ} \mathrm{C}$; WPC $30 \mathrm{C}$ whey protein concentrate stored at $30^{\circ} \mathrm{C}$; SPP $20 \mathrm{C}$, soluble protein powder stored at $20^{\circ} \mathrm{C}$; SPP $30 \mathrm{C}$, soluble protein powder stored at $30^{\circ} \mathrm{C}$ 
Figure 2: Whiteness of stored protein powders (SPP and WPC) stored at 20 and $30^{\circ} \mathrm{C}$

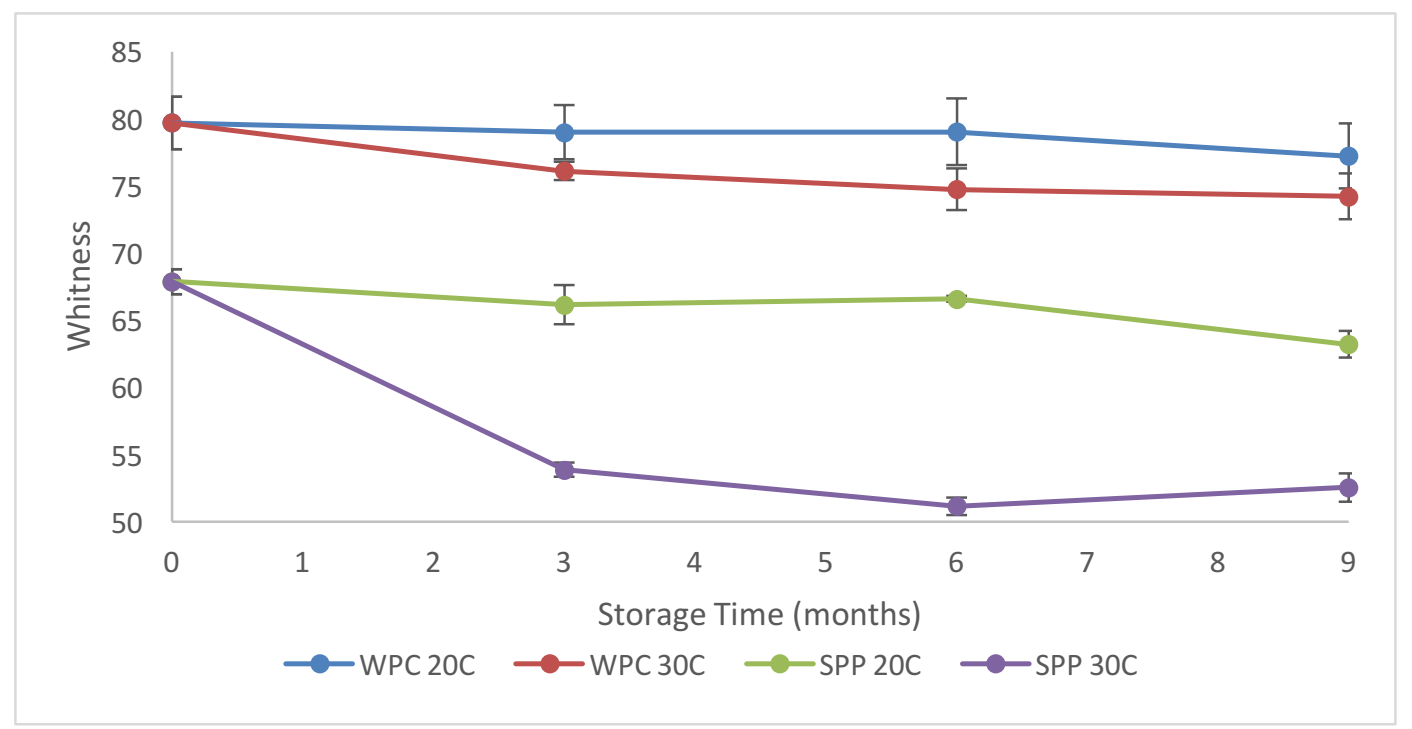

WPC $20 \mathrm{C}$, whey protein concentrate stored at $20^{\circ} \mathrm{C}$; WPC $30 \mathrm{C}$ whey protein concentrate stored at $30^{\circ} \mathrm{C}$; SPP $20 \mathrm{C}$, soluble protein powder stored at $20^{\circ} \mathrm{C}$; SPP $30 \mathrm{C}$, soluble protein powder stored at $30^{\circ} \mathrm{C}$ 
Figure 3: Changes in $\mathrm{pH}$ as a result of storage of SPP and $\mathrm{WPC}$ at 20 or $30^{\circ} \mathrm{C}$ for 9 months

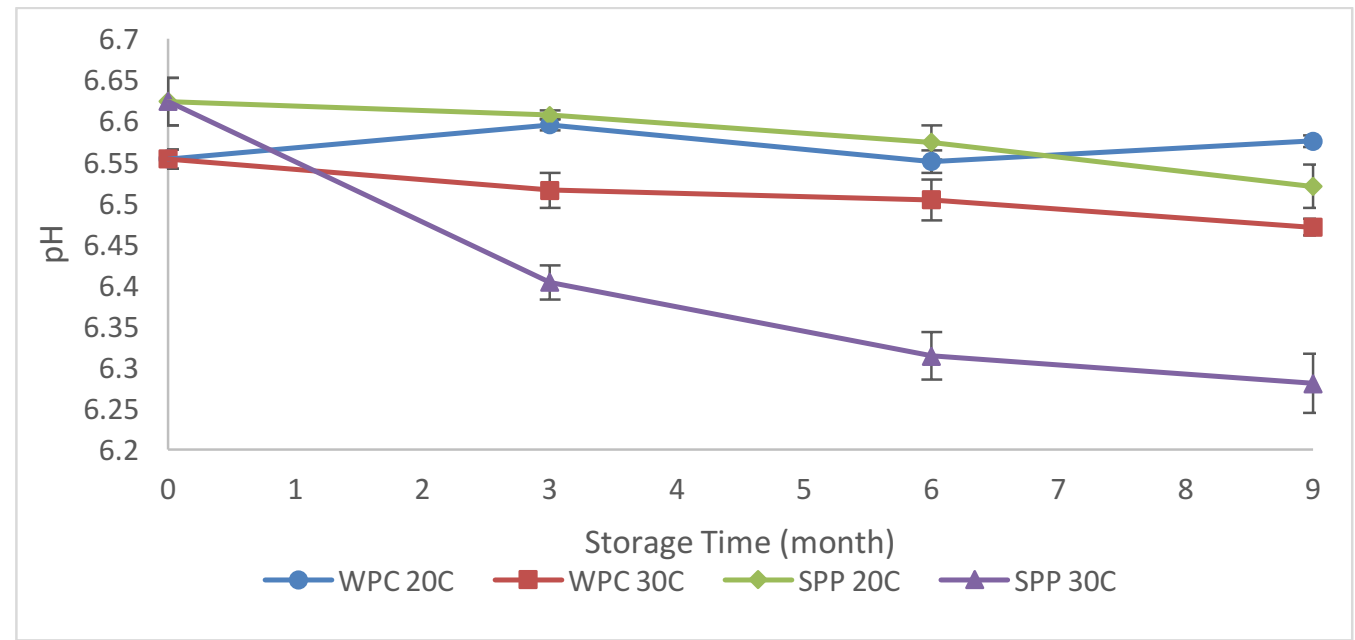

WPC $20 \mathrm{C}$, whey protein concentrate stored at $20^{\circ} \mathrm{C}$; WPC $30 \mathrm{C}$ whey protein concentrate stored at $30^{\circ} \mathrm{C}$; SPP $20 \mathrm{C}$, soluble protein powder stored at $20^{\circ} \mathrm{C}$; SPP $30 \mathrm{C}$, soluble protein powder stored at $30^{\circ} \mathrm{C}$ 
Figure 4: Lipid oxidation values of SPP and WPC stored for 9 months at 20 or $30^{\circ} \mathrm{C}$

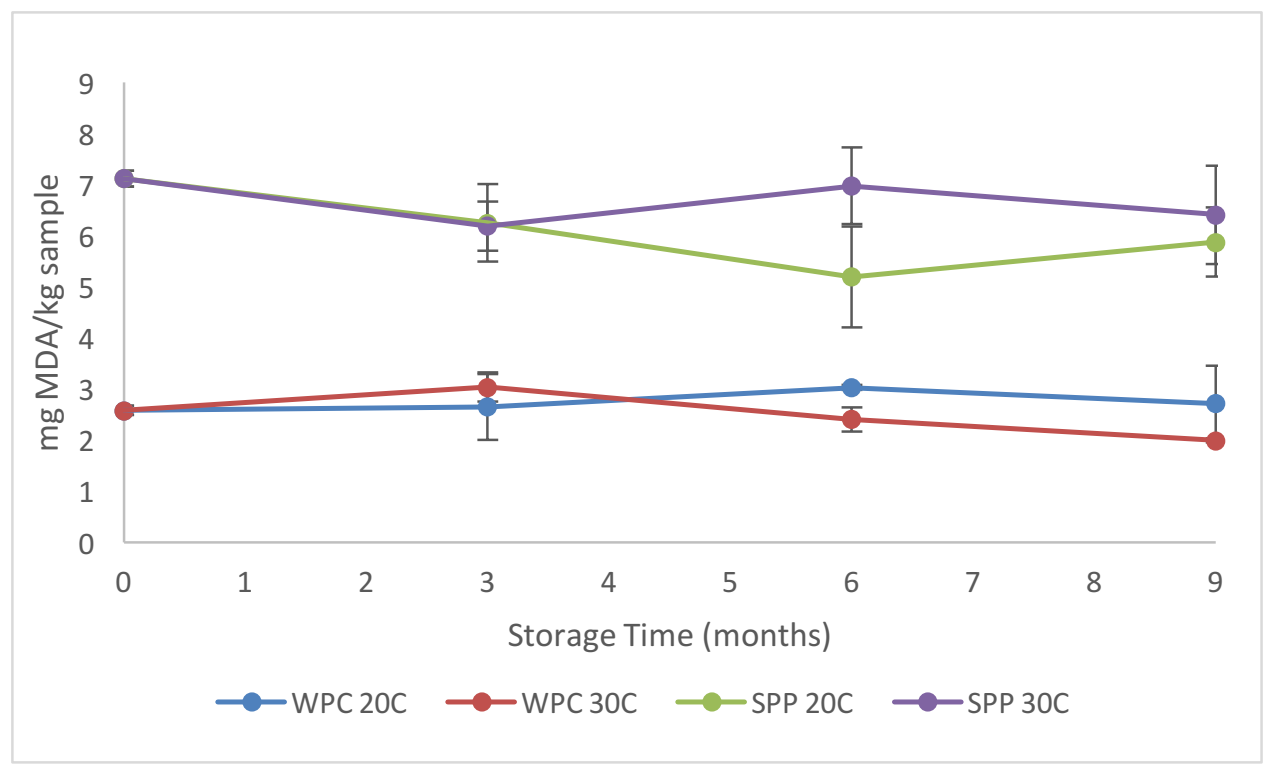

WPC $20 \mathrm{C}$, whey protein concentrate stored at $20^{\circ} \mathrm{C}$; WPC $30 \mathrm{C}$ whey protein concentrate stored at $30^{\circ} \mathrm{C}$; SPP $20 \mathrm{C}$, soluble protein powder stored at $20^{\circ} \mathrm{C}$; SPP $30 \mathrm{C}$, soluble protein powder stored at $30^{\circ} \mathrm{C}$ 
Table 1: Proximate composition ( $\%$ dry weight basis) of the recovered soluble protein powder and whey protein concentrate.

\begin{tabular}{cccc}
\hline Sample & Nitrogen (\%) & Lipid (\%) & Ash (\%) \\
\hline SPP & $81.66 \pm 1.13$ & $3.98 \pm 0.66$ & $14.14 \pm 0.69$ \\
WPC 80 & $77.46 \pm 0.22$ & $0.83 \pm 0.11$ & $3.41 \pm 0.14$ \\
\hline \multicolumn{4}{l}{ SPP, Soluble protein powder; WPC 80, Whey protein concentrate $(80 \%)$}
\end{tabular}


Table 2: Change in amino acid profile of WPC stored at $20^{\circ} \mathrm{C}$ for 3,6 , and 9 months

Component

(mg/g protein)

Initial Content

3 Month

6 Month

9 Month

EAAs

Arginine

$28.90 \pm 0.10$

$-0.07 \pm 0.00^{\mathrm{A}}$

$-0.07 \pm 0.00^{\mathrm{A}}$

$-0.21 \pm 0.00^{\mathrm{B}}$

Histidine

$21.03 \pm 0.0$

$-0.14 \pm 0.00$

$-0.14 \pm 0.00$

$-0.21 \pm 0.10$

Isoleucine

$69.07 \pm 0.39$

$-0.42 \pm 0.39$

$-0.56 \pm 0.20$

$-0.35 \pm 1.28$

Leucine

$117.95 \pm 0.39$

$-0.21 \pm 0.30$

$0.07 \pm 0.10$

$-0.28 \pm 0.20$

Lysine

$102.63 \pm 0.20$

$-1.33 \pm 0.10^{\mathrm{A}}$

$-1.74 \pm 0.10^{\mathrm{A}}$

$-2.58 \pm 0.30^{\mathrm{B}}$

Cysteine + Methionine

$50.34 \pm 0.30$

$0.07 \pm 0.00$

$0.14 \pm 0.30$

$-0.35 \pm 0.40$

Phenylalanine + Tyrosine

$69.14 \pm 0.49$

$0.00 \pm 0.10$

$-0.14 \pm 0.1$

$-0.35 \pm 0.00$

Threonine

$73.25 \pm 0.39$

$0.42 \pm 0.00$

$0.84 \pm 0.20$

$-0.141 .18$

Tryptophan

$22.35 \pm 0.30$

$-0.07 \pm 0.00$

$-0.70 \pm 0.10$

$-0.49 \pm 0.39$

Valine

$66.08 \pm 0.10$

$-0.28 \pm 0.10$

$-0.35 \pm 0.00$

$-0.35 \pm 0.39$

NEAAs

\begin{tabular}{ccccc} 
Alanine & $56.05 \pm 0.10$ & $-0.14 \pm 0.10$ & $-0.07 \pm 0.20$ & $-0.35 \pm 0.00$ \\
Aspartic Acid & $114.12 \pm 0.30$ & $0.35 \pm 0.39$ & $0.28 \pm 0.10$ & $-0.35 \pm 0.20$ \\
Cysteine & $27.02 \pm 0.20$ & $0.00 \pm 0.00$ & $0.07 \pm 0.30$ & $-0.28 \pm 0.39$ \\
Glutamic acid & $189.32 \pm 0.30$ & $-0.42 \pm 0.30^{\mathrm{A}}$ & $0.07 \pm 0.39^{\mathrm{A}}$ & $-1.46 \pm 0.20^{\mathrm{B}}$ \\
Glycine & $20.26 \pm 0.10$ & $0.00 \pm 0.10$ & $0.00 \pm 0.10$ & $-0.21 \pm 0.00$ \\
Proline & $62.94 \pm 0.20$ & $0.07 \pm 1.08$ & $0.07 \pm 0.68$ & $0.21 \pm 0.30$ \\
Serine & $52.36 \pm 0.20$ & $0.70 \pm 0.20$ & $1.18 \pm 0.49$ & $-0.21 \pm 2.07$ \\
Tyrosine & $33.14 \pm 0.39$ & $0.00 \pm 0.00$ & $-0.14 \pm 0.00$ & $-0.21 \pm 0.10$ \\
Taurine & $0.00 \pm 0.0$ & $0.00 \pm 0.00$ & $0.00 \pm 0.00$ & $0.00 \pm 0.00$ \\
\hline
\end{tabular}

EAAs, Essential Amino Acids; NEAAs, Non-essential Amino Acids.

A, B, Values with different letters in a row are significantly different as determined by Tukey’s HD $(p<0.05)$ 
Table 3: Change in amino acid profile of WPC stored at $30^{\circ} \mathrm{C}$ for 3,6 , and 9 months.

Component

(mg/g protein)

Initial Content 3 Months 6 Months 9 Months

\begin{tabular}{ccccc} 
EAAs & & & & \\
Arginine & $28.90 \pm 0.10$ & $-0.35 \pm 0.00$ & $-0.14 \pm 0.10$ & $-0.14 \pm 0.10$ \\
Histidine & $21.03 \pm 0.0$ & $-0.28 \pm 0.00$ & $-0.21 \pm 0.10$ & $-0.21 \pm 0.10$ \\
Isoleucine & $69.07 \pm 0.39$ & $0.28 \pm 0.39$ & $0.00 \pm 0.00$ & $-0.28 \pm 0.20$ \\
Leucine & $117.95 \pm 0.39$ & $-0.42 \pm 0.20$ & $-0.21 \pm 0.10$ & $-0.07 \pm 0.10$ \\
Lysine & $102.63 \pm 0.20$ & $-3.76 \pm 0.20$ & $-4.67 \pm 0.30$ & $-5.15 \pm 0.79$ \\
Cysteine + Methionine & $50.34 \pm 0.30$ & $-0.14 \pm 0.49$ & $0.14 \pm 0.10$ & $0.00 \pm 0.49$ \\
Phenylalanine + Tyrosine & $69.14 \pm 0.49$ & $-0.35 \pm 0.59$ & $-0.35 \pm 0.00$ & $0.00 \pm 0.30$ \\
Threonine & $73.25 \pm 0.39$ & $-0.56 \pm 0.00$ & $-0.07 \pm 0.10$ & $0.42 \pm 0.79$ \\
Tryptophan & $22.35 \pm 0.30$ & $-0.49 \pm 0.00$ & $-0.84 \pm 0.30$ & $0.00 \pm 0.30$ \\
Valine & $66.08 \pm 0.10$ & $-0.35 \pm 0.00$ & $-0.35 \pm 0.20$ & $-0.56 \pm 0.49$ \\
& & & & \\
NEAAs & & & & \\
Alanine & $56.05 \pm 0.10$ & $-0.56 \pm 0.10$ & $-0.42 \pm 0.30$ & $-0.42 \pm 0.69$ \\
Aspartic Acid & $114.12 \pm 0.30$ & $0.14 \pm 0.89$ & $-0.07 \pm 0.20$ & $0.28 \pm 1.08$ \\
Cysteine & $27.02 \pm 0.20$ & $-0.07 \pm 0.30$ & $0.14 \pm 0.00$ & $0.07 \pm 0.30$ \\
Glutamic acid & $189.32 \pm 0.30$ & $-1.67 \pm 0.10$ & $-0.84 \pm 0.30$ & $-1.32 \pm 2.95$ \\
Glycine & $20.26 \pm 0.10$ & $-0.28 \pm 0.10$ & $-0.21 \pm 0.20$ & $-0.21 \pm 0.39$ \\
Proline & $62.94 \pm 0.20$ & $-0.84 \pm 0.00$ & $0.00 \pm 0.59$ & $0.14 \pm 0.39$ \\
Serine & $52.36 \pm 0.20$ & $-1.25 \pm 0.20$ & $-0.35 \pm 0.10$ & $-0.14 \pm 1.57$ \\
Tyrosine & $33.14 \pm 0.39$ & $-0.28 \pm 0.39$ & $-0.21 \pm 0.10$ & $0.00 \pm 0.20$ \\
Taurine & $0.00 \pm 0.0$ & $0.28 \pm 0.39$ & $0.00 \pm 0.00$ & $0.00 \pm 0.00$ \\
\hline
\end{tabular}

EAAs, Essential Amino Acids; NEAAs, Non-essential Amino Acids.

${ }^{A, B}$ Values with different letters in a row are significantly different as determined by Tukey's HD ( $\left.p<0.05\right)$ 
Table 4: Change in amino acid profile of SPP stored at $20^{\circ} \mathrm{C}$ for 3,6 , and 9 months.

Component

(mg/g protein)
Initial Content

EAAs

Arginine

Histidine

Isoleucine

Leucine

Lysine

Cysteine + Methionine

Phenylalanine + Tyrosine

Threonine

Tryptophan

Valine

\begin{tabular}{cccc}
$40.01 \pm 0.27$ & $-1.34 \pm 0.36$ & $-1.66 \pm 0.45$ & $-0.19 \pm 0.36$ \\
$47.57 \pm 0.09$ & $-0.96 \pm 0.90$ & $-1.15 \pm 0.45$ & $-2.82 \pm 0.09$ \\
$40.14 \pm 0.27$ & $-0.51 \pm 1.36$ & $0.19 \pm 0.00$ & $0.83 \pm 0.36$ \\
$65.81 \pm 0.18$ & $-1.60 \pm 0.27$ & $-1.73 \pm 0.09$ & $-0.06 \pm 0.63$ \\
$81.31 \pm 0.0$ & $-4.87 \pm 1.09$ & $-5.70 \pm 0.63$ & $-4.61 \pm 0.72$ \\
$28.36 \pm 0.09$ & $-0.70 \pm 0.36$ & $-0.77 \pm 0.27$ & $-0.77 \pm 0.45$ \\
$69.53 \pm 0.54$ & $-1.66 \pm 0.54$ & $-2.30 \pm 0.72$ & $0.38 \pm 0.72$ \\
$34.12 \pm 0.09$ & $-1.22 \pm 0.36$ & $-1.66 \pm 0.09$ & $-0.58 \pm 0.36$ \\
$11.97 \pm 0.09$ & $-0.06 \pm 0.18$ & $-0.64 \pm 0.45$ & $-0.19 \pm 0.18$ \\
$49.36 \pm 0.27$ & $-0.96 \pm 1.44$ & $-0.51 \pm 0.27$ & $0.58 \pm 0.36$ \\
\hline
\end{tabular}

NEAAs

\begin{tabular}{ccccc} 
Alanine & $52.11 \pm 0.0$ & $-1.15 \pm 0.54$ & $-1.54 \pm 0.54$ & $-0.06 \pm 0.45$ \\
Aspartic Acid & $87.00 \pm 0.09$ & $-2.62 \pm 1.09$ & $-2.56 \pm 0.63$ & $-0.26 \pm 1.00$ \\
Cysteine & $11.08 \pm 0.09$ & $0.32 \pm 0.18$ & $0.38 \pm 0.09$ & $0.19 \pm 0.18$ \\
Glutamic acid & $89.95 \pm 1.18$ & $-2.30 \pm 0.09$ & $-3.46 \pm 1.00$ & $-1.41 \pm 1.00$ \\
Glycine & $56.08 \pm 0.0$ & $-0.83 \pm 1.18$ & $-0.83 \pm 1.00$ & $-0.70 \pm 0.09$ \\
Proline & $25.74 \pm 0.18$ & $-0.70 \pm 0.27^{\mathrm{AB}}$ & $-1.15 \pm 0.18^{\mathrm{B}}$ & $0.00 \pm 0.00^{\mathrm{A}}$ \\
Serine & $31.31 \pm 1.00$ & $-1.60 \pm 1.81$ & $-2.82 \pm 0.09$ & $-1.47 \pm 0.54$ \\
Tyrosine & $25.22 \pm 0.18$ & $-0.70 \pm 0.09$ & $-1.41 \pm 0.72$ & $0.13 \pm 0.36$ \\
Taurine & $28.87 \pm 0.09$ & $-0.51 \pm 1.00$ & $-0.83 \pm 0.54$ & $-2.81 \pm 0.45$ \\
\hline
\end{tabular}

EAAs, Essential Amino Acids; NEAAs, Non-essential Amino Acids.

${ }^{A, B}$ Values with different letters in a row are significantly different as determined by Tukey’s HD $(p<0.05)$ 
Table 5: Change amino acid content of SPP stored at $30^{\circ} \mathrm{C}$ for 3,6 , and 9 months

Component

(mg/g protein)

Initial Content

3 Months

6 Months

9 Months

EAAs

\begin{tabular}{lcccc} 
Arginine & $40.01 \pm 0.27$ & $-2.18 \pm 0.09^{\mathrm{A}}$ & $-3.27 \pm 0.18^{\mathrm{B}}$ & $-2.50 \pm 0.00^{\mathrm{A}}$ \\
Histidine & $47.57 \pm 0.09$ & $-6.59 \pm 0.18^{\mathrm{A}}$ & $-11.27 \pm 0.09^{\mathrm{B}}$ & $-11.20 \pm 0.18^{\mathrm{B}}$ \\
Isoleucine & $40.14 \pm 0.27$ & $-1.02 \pm 0.45^{\mathrm{B}}$ & $-2.30 \pm 0.09^{\mathrm{C}}$ & $0.19 \pm 0.00^{\mathrm{A}}$ \\
Leucine & $65.81 \pm 0.18$ & $-2.56 \pm 0.18^{\mathrm{A}}$ & $-4.10 \pm 0.54^{\mathrm{B}}$ & $-2.56 \pm 0.00^{\mathrm{A}}$ \\
Lysine & $81.31 \pm 0.0$ & $-7.87 \pm 0.45^{\mathrm{A}}$ & $-10.50 \pm 0.36^{\mathrm{B}}$ & $-8.32 \pm 0.00^{\mathrm{A}}$ \\
ine + Methionine & $28.36 \pm 0.09$ & $-3.27 \pm 0.18^{\mathrm{A}}$ & $-4.10 \pm 0.27^{\mathrm{B}}$ & $-3.46 \pm 0.09^{\mathrm{AB}}$ \\
alanine + Tyrosine & $69.53 \pm 0.54$ & $-2.62 \pm 0.27$ & $-3.65 \pm 0.27$ & $-2.75 \pm 0.27$ \\
Threonine & $34.12 \pm 0.09$ & $-1.54 \pm 0.09$ & $-1.92 \pm 0.27$ & $-1.98 \pm 0.00$ \\
Tryptophan & $11.97 \pm 0.09$ & $0.00 \pm 0.09$ & $-0.51 \pm 0.27$ & $-0.13 \pm 0.09$ \\
$\quad$ Valine & $49.36 \pm 0.27$ & $-1.79 \pm 0.45^{\mathrm{B}}$ & $-3.71 \pm 0.09^{\mathrm{C}}$ & $-0.64 \pm 0.09^{\mathrm{A}}$ \\
\hline
\end{tabular}

Cysteine + Methionine

Phenylalanine + Tyrosine

Threonine

Valine

NEAAs

\begin{tabular}{ccccc} 
Alanine & $52.11 \pm 0.0$ & $-0.90 \pm 0.18^{\mathrm{A}}$ & $-2.11 \pm 0.27^{\mathrm{B}}$ & $-0.90 \pm 0.00^{\mathrm{A}}$ \\
Aspartic Acid & $87.00 \pm 0.09$ & $-3.20 \pm 0.63^{\mathrm{AB}}$ & $-4.74 \pm 0.45^{\mathrm{B}}$ & $-2.69 \pm 0.09^{\mathrm{A}}$ \\
Cysteine & $11.08 \pm 0.09$ & $-0.64 \pm 0.09^{\mathrm{A}}$ & $-1.02 \pm 0.09^{\mathrm{B}}$ & $-0.70 \pm 0.00^{\mathrm{A}}$ \\
Glutamic acid & $89.95 \pm 1.18$ & $-3.33 \pm 1.00$ & $-5.25 \pm 0.81$ & $-3.07 \pm 0.45$ \\
Glycine & $56.08 \pm 0.0$ & $-1.54 \pm 0.18^{\mathrm{A}}$ & $-3.71 \pm 0.00^{\mathrm{C}}$ & $-2.69 \pm 0.18^{\mathrm{B}}$ \\
Proline & $25.74 \pm 0.18$ & $-1.34 \pm 0.45$ & $-2.11 \pm 0.09$ & $-1.28 \pm 0.00$ \\
Serine & $31.31 \pm 1.00$ & $-1.28 \pm 0.09$ & $-0.96 \pm 0.54$ & $-2.24 \pm 0.00$ \\
Tyrosine & $25.22 \pm 0.18$ & $-1.41 \pm 0.18$ & $-1.54 \pm 0.00$ & $-1.60 \pm 0.27$ \\
Taurine & $28.87 \pm 0.09$ & $-2.56 \pm 0.09^{\mathrm{A}}$ & $-4.48 \pm 0.27^{\mathrm{B}}$ & $-4.42 \pm 0.18^{\mathrm{B}}$ \\
\hline
\end{tabular}

EAAs, Essential Amino Acids; NEAAs, Non-essential Amino Acids.

${ }^{A}, B, C$ Values with different letters in a row are significantly different as determined by Tukey's HD (p < 0.05$)$ 


\section{Chapter V}

\section{Appendix}

Figure 1: Nutrition facts and ingredients of whey protein concentrate purchased from a food whole sale website (bulkfoods.com).

\begin{tabular}{|c|c|c|c|}
\hline Amount Per Serving & & & \\
\hline Calories 120 & & Calor & es from Fat 15 \\
\hline & & & \% Daily Value* \\
\hline Total Fat $1.5 \mathrm{~g}$ & & & $2 \%$ \\
\hline Saturated Fa & $0.5 \mathrm{~g}$ & & $3 \%$ \\
\hline Trans Fat $0 \mathrm{~g}$ & & & \\
\hline Cholesterol 50 & & & $17 \%$ \\
\hline Sodium $120 \mathrm{mg}$ & & & $5 \%$ \\
\hline Total Carbohyc & ate $3 g$ & & $1 \%$ \\
\hline Dietary Fiber & & & $0 \%$ \\
\hline Sugars 3g & & & \\
\hline Protein 23g & & & $46 \%$ \\
\hline Vitamin A 0\% & $\bullet$ & & Vitamin C 0\% \\
\hline $\begin{array}{l}\text { Calcium } 8 \% \\
\text { *Percent Daily Value } \\
\text { Values may be high }\end{array}$ & $\begin{array}{l}\bullet \\
\text { re based or } \\
\text { or lower dep }\end{array}$ & $\begin{array}{l}2,000 \text { cal } \\
\text { iding on } y\end{array}$ & $\begin{array}{l}\text { Iron 0\% } \\
\text { rie diet. Your Daily } \\
\text { bur calorie needs. }\end{array}$ \\
\hline & Calories & 2,000 & 2,500 \\
\hline Total Fat & Less than & $65 \mathrm{~g}$ & $80 \mathrm{~g}$ \\
\hline Sat Fat & Less than & $20 \mathrm{~g}$ & $25 \mathrm{~g}$ \\
\hline Cholesterol & Less than & $300 \mathrm{mg}$ & $300 \mathrm{mg}$ \\
\hline Sodium & Less than & $2400 \mathrm{mg}$ & $2400 \mathrm{mg}$ \\
\hline Total Carbohydrate & & $300 \mathrm{~g}$ & $375 \mathrm{~g}$ \\
\hline Dietary Fiber & & $25 \mathrm{~g}$ & $30 \mathrm{~g}$ \\
\hline
\end{tabular}

Ingredients: Whey (milk) Protein Concentrate and Soy Lecithin (solubilizer) 
Figure 2: Comparison of total essential amino acid content $(\mathbf{A})$ and lysine content $(\mathbf{B})$ between stored WPC and SPP samples at 0, 3, 6, and 9 months.
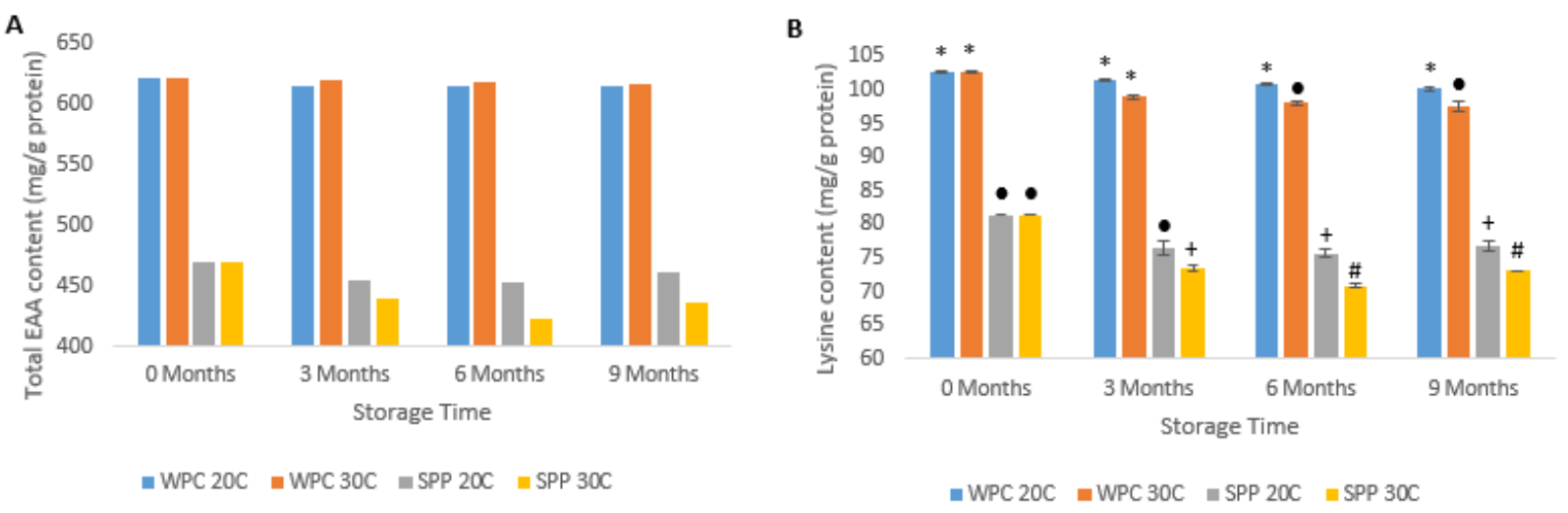

EAAs, Essential Amino Acids; NEAAs, SPP, Soluble Protein Powder; WPC, whey protein concentrate.

$+, \bullet, *$,\# Values with different symbol for each protein powder are significantly different as determined by Tukey's HD (p $<0.05)$ 
Figure 3: Degradation of total essential amino acid content (A) and lysine content (B) in WPC and SPP stored for 9 months and 20 and $30^{\circ} \mathrm{C}$

A

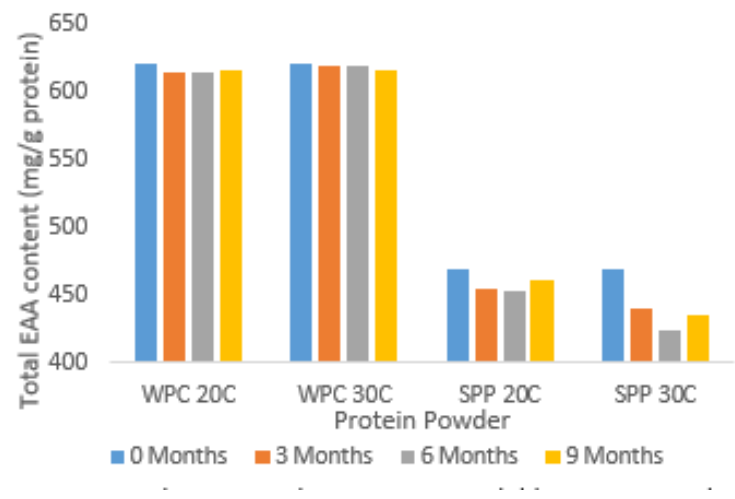

B

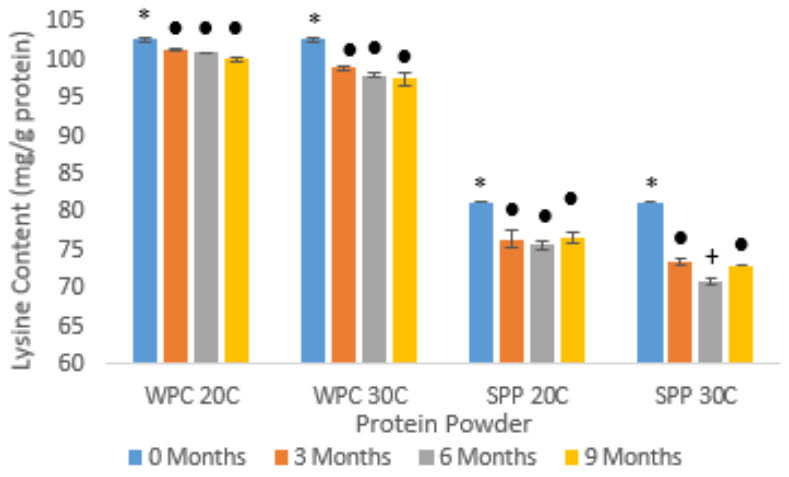

EAAs, Essential Amino Acids; NEAAs, SPP, Soluble Protein Powder; WPC, whey protein concentrate.

$+, \bullet, *$ Values with different symbol for each protein powder are significantly different as determined by Tukey’s HD (p < $0.05)$ 
Table 1: Water activity of whey protein concentrate and soluble protein powder stored at 20 and $30^{\circ} \mathrm{C}$

\begin{tabular}{lllll}
\hline Sample & Initial & 3 months & 6 months & 9 months \\
\hline WPC 20C & $0.26 \pm 0.00^{\mathrm{Ca}}$ & $0.29 \pm 0.01^{\mathrm{ABb}}$ & $0.29 \pm 0.01^{\mathrm{Ab}}$ & $0.27 \pm 0.00^{\mathrm{BCc}}$ \\
WPC 30C & $0.26 \pm 0.00^{\mathrm{Ca}}$ & $0.27 \pm 0.00^{\mathrm{Bb}}$ & $0.3 \pm 0.00^{\mathrm{Ab}}$ & $0.29 \pm 0.01^{\mathrm{Ab}}$ \\
SPP 20C & $0.16 \pm 0.03^{\mathrm{Cb}}$ & $0.21 \pm 0.01^{\mathrm{Bc}}$ & $0.20 \pm 0.00^{\mathrm{Bc}}$ & $0.27 \pm 0.00^{\mathrm{Ac}}$ \\
SPP 30C & $0.16 \pm 0.03^{\mathrm{Cb}}$ & $0.37 \pm 0.00^{\mathrm{Ba}}$ & $0.41 \pm 0.00^{\mathrm{Aa}}$ & $0.43 \pm 0.00^{\mathrm{Aa}}$ \\
\hline
\end{tabular}

WPC $20 \mathrm{C}$, whey protein concentrate stored at $20^{\circ} \mathrm{C}$; WPC $30 \mathrm{C}$ whey protein concentrate stored at $30^{\circ} \mathrm{C}$; SPP $20 \mathrm{C}$, soluble protein powder stored at $20^{\circ} \mathrm{C}$; SPP $30 \mathrm{C}$, soluble protein powder stored at $30^{\circ} \mathrm{C}$

$A, B, C$ Values with different letters in a row are significantly different as determined by Tukey's $H D(p<0.05)$

${ }^{a, b, c}$ Values with different letters in a column are significantly different as determined by Tukey's HD $(p<0.05)$ 
Table 2: Whiteness of whey protein concentrate and soluble protein powder stored at 20 and $30^{\circ} \mathrm{C}$

\begin{tabular}{lllll}
\hline Sample & Initial & 3 months & 6 months & 9 months \\
\hline WPC 20C & $79.69 \pm 1.94^{\mathrm{a}}$ & $79.00 \pm 2.02^{\mathrm{a}}$ & $79.03 \pm 2.49^{\mathrm{a}}$ & $77.21 \pm 2.41^{\mathrm{a}}$ \\
WPC 30C & $79.69 \pm 1.95^{\mathrm{Aa}}$ & $76.09 \pm 0.69^{\mathrm{ABa}}$ & $74.75 \pm 1.54^{\mathrm{Ba}}$ & $74.23 \pm 1.70^{\mathrm{Ba}}$ \\
SPP 20C & $67.88 \pm 0.92^{\mathrm{Ab}}$ & $66.16 \pm 1.49^{\mathrm{Ab}}$ & $66.59 \pm 0.21^{\mathrm{Ab}}$ & $63.22 \pm 1.01^{\mathrm{Bb}}$ \\
SPP 30C & $67.88 \pm 0.93^{\mathrm{Ab}}$ & $53.88 \pm 0.54^{\mathrm{Bc}}$ & $51.17 \pm 0.64^{\mathrm{Bc}}$ & $52.57 \pm 1.05^{\mathrm{Bc}}$ \\
\hline
\end{tabular}

WPC $20 \mathrm{C}$, whey protein concentrate stored at $20^{\circ} \mathrm{C}$; WPC $30 \mathrm{C}$ whey protein concentrate stored at $30^{\circ} \mathrm{C}$; SPP $20 \mathrm{C}$, soluble protein powder stored at $20^{\circ} \mathrm{C}$; SPP $30 \mathrm{C}$, soluble protein powder stored at $30^{\circ} \mathrm{C}$

${ }^{A, B}$ Values with different letters in a row are significantly different as determined by Tukey's HD $(p<0.05)$

${ }^{a, b, c}$ Values with different letters in a column are significantly different as determined by Tukey's HD $(p<0.05)$ 
Table 3: $\mathrm{pH}$ of whey protein concentrate and soluble protein powder stored at 20 and $30^{\circ} \mathrm{C}$

\begin{tabular}{lllll}
\hline Sample & Initial & 3 months & 6 months & 9 months \\
\hline WPC 20C & $6.55 \pm 0.01^{\mathrm{b}}$ & $6.59 \pm 0.01^{\mathrm{a}}$ & $6.55 \pm 0.01^{\mathrm{a}}$ & $6.58 \pm 0.01^{\mathrm{a}}$ \\
WPC 30C $^{\mathrm{Ab}}$ & $6.55 \pm 0.01^{\mathrm{Ab}}$ & $6.52 \pm 0.02^{\mathrm{Aba}}$ & $6.50 \pm 0.03^{\mathrm{ABa}}$ & $6.47 \pm 0.01^{\mathrm{Bb}}$ \\
SPP 20C & $6.62 \pm 0.03^{\mathrm{Aa}}$ & $6.61 \pm 0.01^{\mathrm{Aba}}$ & $6.57 \pm 0.02^{\mathrm{BCa}}$ & $6.52 \pm 0.03^{\mathrm{Cab}}$ \\
SPP 30C & $6.62 \pm 0.03^{\mathrm{Aa}}$ & $6.40 \pm 0.02^{\mathrm{Bb}}$ & $6.31 \pm 0.03^{\mathrm{Ca}}$ & $6.28 \pm 0.04^{\mathrm{Cc}}$ \\
\hline
\end{tabular}

WPC $20 \mathrm{C}$, whey protein concentrate stored at $20^{\circ} \mathrm{C}$; WPC $30 \mathrm{C}$ whey protein concentrate stored at $30^{\circ} \mathrm{C}$; SPP $20 \mathrm{C}$, soluble protein powder stored at $20^{\circ} \mathrm{C}$; SPP $30 \mathrm{C}$, soluble protein powder stored at $30^{\circ} \mathrm{C}$

$A, B, C$ Values with different letters in a row are significantly different as determined by Tukey's HD $(p<0.05)$

${ }^{a, b, c}$ Values with different letters in a column are significantly different as determined by Tukey's HD $(p<0.05)$ 
Table 4: Lipid oxidation of whey protein concentrate and soluble protein powder stored at 20 and $30^{\circ} \mathrm{C}$

\begin{tabular}{ccccc}
\hline $\begin{array}{c}\text { Sample } \\
\text { (mg MDA/ kg sample) }\end{array}$ & Initial & 3 months & 6 months & 9 months \\
\hline WPC 20C & $2.59 \pm 0.09^{\mathrm{b}}$ & $2.65 \pm 0.64^{\mathrm{b}}$ & $3.04 \pm 0.05^{\mathrm{b}}$ & $2.72 \pm 0.74^{\mathrm{b}}$ \\
WPC 30C & $2.59 \pm 0.09^{\mathrm{Ab}}$ & $3.04 \pm 0.28^{\mathrm{Ab}}$ & $2.41 \pm 0.23^{\mathrm{ABb}}$ & $2.00 \pm 0.03^{\mathrm{Bb}}$ \\
SPP 20C & $7.12 \pm 0.16^{\mathrm{a}}$ & $6.26 \pm 0.75^{\mathrm{a}}$ & $5.20 \pm 0.99^{\mathrm{ab}}$ & $5.88 \pm 0.68^{\mathrm{a}}$ \\
SPP 30C & $7.12 \pm 0.17^{\mathrm{a}}$ & $6.19 \pm 0.47^{\mathrm{a}}$ & $6.98 \pm 0.75^{\mathrm{a}}$ & $6.42 \pm 0.96^{\mathrm{a}}$
\end{tabular}

WPC $20 \mathrm{C}$, whey protein concentrate stored at $20^{\circ} \mathrm{C}$; WPC $30 \mathrm{C}$ whey protein concentrate stored at $30^{\circ} \mathrm{C}$; SPP $20 \mathrm{C}$, soluble protein powder stored at $20^{\circ} \mathrm{C}$; SPP $30 \mathrm{C}$, soluble protein powder stored at $30^{\circ} \mathrm{C}$

$A, B, C$ Values with different letters in a row are significantly different as determined by Tukey's $\operatorname{HD}(p<0.05)$

${ }^{a, b, c}$ Values with different letters in a column are significantly different as determined by Tukey's HD $(p<0.05)$ 
Table 5: Amino acid profile of WPC stored at $20^{\circ} \mathrm{C}$ for 9 months

Component

(mg/g protein)

EAAs

Arginine

Histidine

Isoleucine

Leucine

Lysine

Cysteine + Methionine

Phenylalanine + Tyrosine

Threonine

Tryptophan

Valine

Total EAAs
Initial

3 Months
6 Months

9 Months

NEAAs

Alanine

Aspartic Acid

$$
56.05 \pm 0.10
$$

$$
55.91 \pm 0.10
$$

$55.98 \pm 0.20$

$55.70 \pm 0.0$

Cysteine

$114.12 \pm 0.30$

$114.47 \pm 0.40$

$114.40 \pm 0.10$

$113.77 \pm 0.39$

Glutamic acid

Glycine

$27.02 \pm 0.20$

$27.02 \pm 0.0$

$27.09 \pm 0.30$

$26.74 \pm 0.39$

$189.32 \pm 0.30^{\mathrm{A}}$

$188.90 \pm 0.30^{\mathrm{AB}}$

$189.39 \pm 0.39^{\mathrm{A}}$

$187.86 \pm 0.20^{\mathrm{B}}$

Proline

$20.26 \pm 0.10$

$20.26 \pm 0.10$

$20.26 \pm 0.10$

$20.05 \pm 0.0$

Serine

$62.94 \pm 0.20$

$63.01 \pm 1.08$

$63.01 \pm 0.69$

$63.15 \pm 0.30$

Tyrosine

$52.36 \pm 0.20$

$53.06 \pm 0.20$

$53.54 \pm 0$

$52.15 \pm 2.07$

Taurine

$33.14 \pm 0.39$

$33.14 \pm 0.0$

$33.00 \pm 0.49$

$32.93 \pm 0.10$

$$
0.00 \pm 0.0
$$

$0.00 \pm 0.0$

$0.00 \pm 0.0$

$0.00 \pm 0.0$

Total NEAAs

EAAs, Essential Amino Acids; NEAAs, Non-essential Amino Acids.

${ }^{A, B, C}$ Values with different letters in a row are significantly different as determined by Tukey’s HD (p $\left.<0.05\right)$ 
Table 6: Amino acid profile of WPC stored at $30^{\circ} \mathrm{C}$ for 9 months

\begin{tabular}{|c|c|c|c|c|}
\hline $\begin{array}{c}\text { Component } \\
\text { (mg/g protein) }\end{array}$ & Initial & 3 Month & 6 Months & 9 Months \\
\hline \multicolumn{5}{|l|}{ EAAs } \\
\hline Arginine & $28.90 \pm 0.10$ & $28.55 \pm 0.0$ & $28.76 \pm 0.10$ & $28.76 \pm 0.10$ \\
\hline Histidine & $21.03 \pm 0.0$ & $20.75 \pm 0.0$ & $20.82 \pm 0.10$ & $20.82 \pm 0.10$ \\
\hline Isoleucine & $69.07 \pm 0.39$ & $69.35 \pm 0.39$ & $69.07 \pm 0.0$ & $68.79 \pm 0.20$ \\
\hline Leucine & $117.95 \pm 0.39$ & $117.53 \pm 0.20$ & $117.74 \pm 0.10$ & $117.88 \pm 0.10$ \\
\hline Lysine & $102.63 \pm 0.20^{\mathrm{A}}$ & $98.87 \pm 0.20^{\mathrm{B}}$ & $97.97 \pm 0.30^{\mathrm{B}}$ & $97.48 \pm 0.79^{\mathrm{B}}$ \\
\hline Cysteine + Methionine & $50.34 \pm 0.30$ & $50.20 \pm 0.49$ & $50.48 \pm 0.10$ & $50.34 \pm 0.49$ \\
\hline Phenylalanine + Tyrosine & $69.14 \pm 0.49$ & $68.79 \pm 0.59$ & $68.79 \pm 0.0$ & $69.14 \pm 0.30$ \\
\hline Threonine & $73.25 \pm 0.39$ & $72.69 \pm 0.0$ & $73.18 \pm 0.10$ & $73.67 \pm 0.79$ \\
\hline Tryptophan & $22.35 \pm 0.30$ & $21.86 \pm 0.0$ & $21.52 \pm 0.30$ & $22.35 \pm 0.30$ \\
\hline Valine & $66.08 \pm 0.10$ & $65.73 \pm 0.0$ & $65.73 \pm 0.20$ & $65.52 \pm 0.49$ \\
\hline Total EAAs & 620.74 & 614.33 & 614.05 & 614.75 \\
\hline \multicolumn{5}{|l|}{ NEAAs } \\
\hline Alanine & $56.05 \pm 0.10$ & $55.49 \pm 0.10$ & $55.63 \pm 0.29$ & $55.63 \pm 0.70$ \\
\hline Aspartic Acid & $114.12 \pm 0.30$ & $114.26 \pm 0.89$ & $114.05 \pm 0.20$ & $114.40 \pm 1.08$ \\
\hline Cysteine & $27.02 \pm 0.20$ & $26.95 \pm 0.30$ & $27.15 \pm 0.0$ & $27.09 \pm 0.30$ \\
\hline Glutamic acid & $189.32 \pm 0.30$ & $187.65 \pm 0.10$ & $188.48 \pm 0.30$ & $188.00 \pm 2.95$ \\
\hline Glycine & $20.26 \pm 0.10$ & $19.98 \pm 0.10$ & $20.05 \pm 0.20$ & $20.05 \pm 0.39$ \\
\hline Proline & $62.94 \pm 0.20$ & $62.11 \pm 0.0$ & $62.94 \pm 0.59$ & $63.08 \pm 0.39$ \\
\hline Serine & $52.36 \pm 0.20$ & $51.11 \pm 0.20$ & $52.01 \pm 0.10$ & $52.22 \pm 1.58$ \\
\hline Tyrosine & $33.14 \pm 0.39$ & $32.86 \pm 0.39$ & $32.93 \pm 0.10$ & $33.14 \pm 1.58$ \\
\hline Taurine & $0.00 \pm 0.0$ & $0.28 \pm 0.39$ & $0.00 \pm 0.0$ & $0.00 \pm 0.0$ \\
\hline Total NEAAs & 555.21 & 550.69 & 553.27 & 553.61 \\
\hline
\end{tabular}

EAAs, Essential Amino Acids; NEAAs, Non-essential Amino Acids.

${ }^{A, B}$ Values with different letters in a row are significantly different as determined by Tukey’s HD $(p<0.05)$ 
Table 7: Amino acid profile of SPP stored at $20^{\circ} \mathrm{C}$ for 9 months

\begin{tabular}{|c|c|c|c|c|}
\hline $\begin{array}{l}\text { Component } \\
\text { (mg/g protein) }\end{array}$ & Initial & 3 Months & 6 Months & 9 Months \\
\hline \multicolumn{5}{|l|}{ EAAs } \\
\hline Arginine & $40.01 \pm 0.27^{\mathrm{A}}$ & $38.67 \pm 0.36^{\mathrm{AB}}$ & $38.35 \pm 0.45^{\mathrm{B}}$ & $39.82 \pm 0.36^{\mathrm{AB}}$ \\
\hline Histidine & $47.57 \pm 0.09^{\mathrm{A}}$ & $46.61 \pm 0.91^{\mathrm{B}}$ & $46.41 \pm 0.45^{\mathrm{C}}$ & $44.75 \pm 0.09^{\mathrm{C}}$ \\
\hline Isoleucine & $40.14 \pm 0.27$ & $39.63 \pm 1.36$ & $40.33 \pm 0.0$ & $40.97 \pm 0.36$ \\
\hline Leucine & $65.81 \pm 0.18^{\mathrm{A}}$ & $64.21 \pm 0.27^{\mathrm{B}}$ & $64.08 \pm 0.09^{\mathrm{B}}$ & $65.75 \pm 0.63^{\mathrm{A}}$ \\
\hline Lysine & $81.31 \pm 0.0^{\mathrm{A}}$ & $76.44 \pm 1.09^{\mathrm{B}}$ & $75.61 \pm 0.63^{\mathrm{B}}$ & $76.70 \pm 0.72^{\mathrm{B}}$ \\
\hline Cysteine + Methionine & $28.36 \pm 0.09$ & $27.66 \pm 0.36$ & $27.59 \pm 0.27$ & $27.59 \pm 0.36$ \\
\hline Phenylalanine + Tyrosine & $69.53 \pm 0.54^{\mathrm{AB}}$ & $67.86 \pm 0.54^{\mathrm{AB}}$ & $67.22 \pm 0.72^{\mathrm{B}}$ & $69.91 \pm 0.18^{\mathrm{A}}$ \\
\hline Threonine & $34.12 \pm 0.09^{\mathrm{A}}$ & $32.91 \pm 0.36^{\mathrm{BC}}$ & $32.46 \pm 0.09^{\mathrm{C}}$ & $33.55 \pm 0.36^{\mathrm{AB}}$ \\
\hline Tryptophan & $11.97 \pm 0.09$ & $11.91 \pm 0.18$ & $11.33 \pm 0.45$ & $11.78 \pm 0.18$ \\
\hline Valine & $49.36 \pm 0.27$ & $48.40 \pm 1.45$ & $48.85 \pm 0.27$ & $49.94 \pm 0.36$ \\
\hline Total EAAs & 468.18 & 454.29 & 452.24 & 460.76 \\
\hline \multicolumn{5}{|l|}{ NEAAs } \\
\hline Alanine & $52.11 \pm 0.0$ & $50.96 \pm 0.54$ & $50.58 \pm 0.54$ & $52.05 \pm 0.45$ \\
\hline Aspartic Acid & $87.00 \pm 0.09$ & $84.38 \pm 1.09$ & $84.44 \pm 0.63$ & $86.75 \pm 1.00$ \\
\hline Cysteine & $11.08 \pm 0.09$ & $11.40 \pm 0.18$ & $11.46 \pm 0.09$ & $11.27 \pm 0.18$ \\
\hline Glutamic acid & $89.95 \pm 1.18$ & $87.64 \pm 0.09$ & $86.49 \pm 1.00$ & $88.54 \pm 1.00$ \\
\hline Glycine & $56.08 \pm 0.0$ & $55.25 \pm 1.18$ & $55.25 \pm 1.00$ & $55.38 \pm 0.09$ \\
\hline Proline & $25.74 \pm 0.18^{\mathrm{A}}$ & $25.03 \pm 0.27^{\mathrm{AB}}$ & $24.58 \pm 0.18^{\mathrm{B}}$ & $25.74 \pm 0.0^{\mathrm{A}}$ \\
\hline Serine & $31.31 \pm 1.00$ & $29.71 \pm 1.81$ & $28.49 \pm \pm^{\prime} 0.09$ & $29.83 \pm 0.54$ \\
\hline Tyrosine & $25.22 \pm 0.18$ & $24.52 \pm 0.09$ & $23.82 \pm 0.72$ & $25.35 \pm 0.36$ \\
\hline Taurine & $28.87 \pm 0.09^{\mathrm{A}}$ & $28.36 \pm 1.00^{\mathrm{AB}}$ & $28.04 \pm 0.54^{\mathrm{AB}}$ & $26.06 \pm 0.45^{\mathrm{B}}$ \\
\hline Total NEAAs & 407.36 & 397.25 & 393.15 & 400.96 \\
\hline
\end{tabular}

EAAs, Essential Amino Acids; NEAAs, Non-essential Amino Acids.

A, B,C Values with different letters in a row are significantly different as determined by Tukey's HD $(p<0.05)$ 
Table 8: Amino acid profile of SPP stored at $30^{\circ} \mathrm{C}$ for 9 months

\begin{tabular}{|c|c|c|c|c|}
\hline $\begin{array}{l}\text { Component } \\
\text { (mg/g protein) }\end{array}$ & Initial & 3 Months & 6 Months & 9 Months \\
\hline \multicolumn{5}{|l|}{ EAAs } \\
\hline Arginine & $40.01 \pm 0.27^{\mathrm{A}}$ & $37.84 \pm 0.09^{\mathrm{B}}$ & $36.75 \pm 0.18^{\mathrm{C}}$ & $37.52 \pm 0.0^{\mathrm{B}}$ \\
\hline Histidine & $47.57 \pm 0.09^{\mathrm{A}}$ & $40.97 \pm 0.18^{\mathrm{AB}}$ & $36.30 \pm 0.09^{\mathrm{AB}}$ & $36.36 \pm 0.18^{\mathrm{B}}$ \\
\hline Isoleucine & $40.14 \pm 0.27^{\mathrm{AB}}$ & $39.12 \pm 0.45^{\mathrm{B}}$ & $37.84 \pm 0.09^{\mathrm{C}}$ & $40.33 \pm 0.0^{\mathrm{A}}$ \\
\hline Leucine & $65.81 \pm 0.18^{\mathrm{A}}$ & $63.25 \pm 0.18^{\mathrm{B}}$ & $61.72 \pm 0.54^{\mathrm{C}}$ & $63.25 \pm 0.0^{\mathrm{B}}$ \\
\hline Lysine & $81.31 \pm 0.0^{\mathrm{A}}$ & $73.43 \pm 0.45^{\mathrm{B}}$ & $70.81 \pm 0.36^{\mathrm{C}}$ & $72.98 \pm 0.0^{\mathrm{B}}$ \\
\hline Cysteine + Methionine & $28.36 \pm 0.09^{\mathrm{A}}$ & $25.10 \pm 0.18^{\mathrm{B}}$ & $24.26 \pm 0.27^{\mathrm{C}}$ & $24.90 \pm 0.09^{\mathrm{BC}}$ \\
\hline Phenylalanine + Tyrosine & $69.53 \pm 0.54^{\mathrm{A}}$ & $66.90 \pm 0.27^{\mathrm{B}}$ & $65.88 \pm 0.27^{\mathrm{B}}$ & $66.77 \pm 0.27^{\mathrm{B}}$ \\
\hline Threonine & $34.12 \pm 0.09^{\mathrm{A}}$ & $32.59 \pm 0.09^{\mathrm{B}}$ & $32.20 \pm 0.27^{\mathrm{B}}$ & $32.14 \pm 0.0^{\mathrm{B}}$ \\
\hline Tryptophan & $11.97 \pm 0.09$ & $11.97 \pm 0.09$ & $11.46 \pm 0.27$ & $11.84 \pm 0.09$ \\
\hline Valine & $49.36 \pm 0.27^{\mathrm{A}}$ & $47.57 \pm 0.45^{\mathrm{B}}$ & $45.65 \pm 0.09^{\mathrm{C}}$ & $48.72 \pm 0.09^{\mathrm{AB}}$ \\
\hline Total EAAs & 468.18 & 438.73 & 422.86 & 434.83 \\
\hline \multicolumn{5}{|l|}{ NEAAs } \\
\hline Alanine & $52.11 \pm 0.0^{\mathrm{A}}$ & $51.21 \pm 0.18^{\mathrm{B}}$ & $50.00 \pm 0.27^{\mathrm{C}}$ & $51.22 \pm 0.0^{\mathrm{B}}$ \\
\hline Aspartic Acid & $87.00 \pm 0.09^{\mathrm{A}}$ & $83.80 \pm 0.63^{\mathrm{BC}}$ & $82.27 \pm 0.45^{\mathrm{C}}$ & $84.31 \pm 0.09^{\mathrm{B}}$ \\
\hline Cysteine & $11.08 \pm 0.09^{\mathrm{A}}$ & $10.44 \pm 0.09^{\mathrm{B}}$ & $10.05 \pm 0.09^{\mathrm{C}}$ & $10.37 \pm 0.0^{\mathrm{B}}$ \\
\hline Glutamic acid & $89.95 \pm 1.18^{\mathrm{A}}$ & $86.62 \pm 1.00^{\mathrm{AB}}$ & $84.70 \pm 0.81^{\mathrm{B}}$ & $86.88 \pm 0.45^{\mathrm{AB}}$ \\
\hline Glycine & $56.08 \pm 0.0^{\mathrm{A}}$ & $54.55 \pm 0.18^{\mathrm{B}}$ & $52.37 \pm 0.0^{\mathrm{D}}$ & $53.39 \pm 0.18^{\mathrm{C}}$ \\
\hline Proline & $25.74 \pm 0.18^{\mathrm{A}}$ & $24.39 \pm 0.45^{\mathrm{B}}$ & $23.62 \pm 0.09^{\mathrm{B}}$ & $24.46 \pm 0.0^{\mathrm{B}}$ \\
\hline Serine & $31.31 \pm 1.00$ & $30.03 \pm 0.09$ & $30.35 \pm 0.54$ & $29.07 \pm 0.0$ \\
\hline Tyrosine & $25.22 \pm 0.18^{\mathrm{A}}$ & $23.82 \pm 0.18^{\mathrm{B}}$ & $23.69 \pm 0.0^{\mathrm{B}}$ & $23.62 \pm 0.27^{\mathrm{B}}$ \\
\hline Taurine & $28.87 \pm 0.09^{\mathrm{A}}$ & $26.31 \pm 0.09^{\mathrm{B}}$ & $24.39 \pm 0.27^{\mathrm{C}}$ & $24.46 \pm 0.18^{\mathrm{C}}$ \\
\hline Total NEAAs & 407.36 & 391.17 & 381.43 & 387.77 \\
\hline
\end{tabular}

EAAs, Essential Amino Acids; NEAAs, Non-essential Amino Acids.

$A, B, C$ Values with different letters in a row are significantly different as determined by Tukey's $\operatorname{HD}(p<0.05)$ 